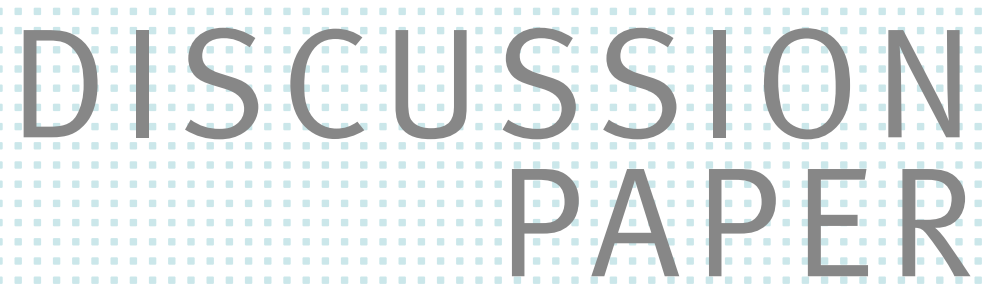

// SEBASTIAN CAMARERO GARCIA AND MARTIN MURMANN

\title{
Unemployment Benefit Duration and Startup Success
}




\title{
Unemployment Benefit Duration and Startup Success*
}

\author{
Sebastian Camarero Garcia ${ }^{\dagger} \quad$ Martin Murmann
}

July 3, 2020

LATEST VERSION HERE

\begin{abstract}
Despite the importance of business creation for the economy and a relevant share of new firms being started out of unemployment, most research has focused on analyzing the effect of unemployment insurance (UI) policies on re-employment outcomes that ignore self-employment. In this paper, we assess how UI benefit duration affects the motivation for creating a startup while unemployed and the subsequent firms' success. To do so, we create a comprehensive dataset on founders in Germany that links administrative social insurance with survey data. Exploiting reform- and age-based exogenous variations in potential benefit duration (PBD) within the German UI system, we find that longer PBD leads to longer actual unemployment duration for those becoming self-employed. Furthermore, the UI duration elasticity for these individuals is higher than common estimates for those individuals becoming re-employed. With increasing unemployment benefit duration, the founders' outcomes in terms of self-assessed motivation, sales, and employment growth lessen. This overall causal effect of PBD can be rationalized with a mix of composition and individual-level duration effects. Therefore, our findings suggest that it is important to consider the fiscal externality of UI on startup success when it comes to the (optimal) design of UI systems.
\end{abstract}

JEL-Classifications: D22, J21, J23, J44, J62, J64, J65, L11, L25, L26, M13

Keywords: entrepreneurship, unemployment insurance, fiscal externality

\footnotetext{
*Both authors declare that they have no material interests that relate to the findings of this paper. We would like to thank Uschi Backes-Gellner, Andreas Gulyas, Eckhard Janeba, Ulrich Kaiser, Ed Lazear, Stephen Machin, Andreas Peichl, Arthur Seibold, David Schönholzer, Sebastian Siegloch, Holger Stichnoth and Michèle Tertilt for helpful comments. We also thank the audience at the Public/Macro Seminar of the University of Mannheim, the Macro Seminar of the Ifo-Institute Munich, and the referees/discussants at the DRUID Copenhagen, IIPF Glasgow, EALE Uppsala, NTA Tampa 2019 conferences for helpful comments. We are grateful to Panos Mavrokonstantis who supported us in developing this paper. Sebastian Camarero Garcia acknowledges financial support by the Cusanuswerk and the fellowship of the German National Academic Foundation. This has been the Job Market Paper of Sebastian Camarero Garcia.

$\dagger$ University of Mannheim, L7 1, Mannheim, Germany and Leibniz Centre for European Economic Research (ZEW Mannheim). Email: sebastian.camarero.garcia@gess.uni-mannheim.de

†University of Zurich, Affolternstr. 56, Zurich, Switzerland and Leibniz Centre for European Economic Research (ZEW Mannheim). Email: martin.murmann@uzh.ch
} 


\section{Introduction}

Business creation plays an important economic role in stimulating productivity, fostering structural change, and, foremost, generating jobs for the founders and their employees (Aghion et al., 2009; Dent et al., 2016; Haltiwanger et al., 2013). Self-employment accounts for 10-15 percent of the labor force in most OECD countries, and self-employment arising from unemployment is important economically, as one quarter of all new businesses is started out of unemployment. ${ }^{1}$ The popularity of policy tools that promote startup activity by the unemployed in order to pave the way out of economic crises (such as the one currently beginning as a result of the global Covid-19 pandemic) may even lead to more startups arising from unemployment in the near future. On a more permanent basis, the spread of new forms of employment in the digital economy (e.g. Uber drivers) will most likely further increase the relevance of transitions from unemployment to self-employment. Recent research in public economics demonstrates that the generosity of unemployment insurance (UI) systems in terms of potential benefit duration (PBD) and benefit levels affects the re-employment outcomes of those transitioning from unemployment to (dependent) employment. Despite their economic importance, however, transitions from unemployment to self-employment (business creations) are largely ignored and little is known about how the design of UI affects the behavior of potential entrepreneurs and the subsequent performance of their firms. Therefore, our paper sheds light on this topic by analyzing how the potential UI benefit duration affects the actual unemployment duration of those transitioning to self-employment, their motivations for starting firms, and the success of their firms in terms of sales and employment growth. ${ }^{2}$

The effect of longer PBD on self-employment outcomes seems unclear a priori. On the one hand, when longer PBD incentivizes longer actual unemployment, losses in financial, social, and human capital might lead to a gradual decrease in startup quality. For instance,

\footnotetext{
${ }^{1}$ For instance, according to Spanish administrative data, up to 50 percent of startups founded between 2005-2017 were started out of unemployment (Camarero Garcia and Hansch, 2020). According to our data, in Germany, the empirical setting of this paper, around 25-30 percent of all founders between 2005-2015 were unemployed directly before starting their firms. According to data from the Mannheim Enterprise Panel on Germany, there were, on average, around 200,000 startups each year between 2000 and 2015. This total corresponds to about 50,000-60,000 startups arising from unemployment per year. A considerable fraction of these startups will employ additional personnel. Since it has been shown that startups often recruit previously unemployed workers (Coad et al., 2017), the absolute importance of startups arising from unemployment for transitions out of unemployment can be expected to be even higher. Hence, though self-employment accounts for a smaller fraction of the total labor force than dependent employment, new firms can be considered incubators of (re)-employment (Haltiwanger et al., 2013).

${ }^{2}$ Concerning the notation in our paper: when discussing self-employment, we refer to labor market status to distinguish unemployment, employment and self-employment. Within the labor market status of self-employment, the term founder refers to the person starting a firm and covers both firms with and without employees. The term entrepreneur is used to focus on a founder who continues to run a firm after starting it. The term startup refers to the act of starting a firm and is used as a synonym for the new firm.
} 
longer unemployment duration could decrease financial means, increase difficulties in attracting external financial capital (due to decreasing collateral or stigmatization), lead to losses in business contacts, or lead to a depreciation of skills and knowledge. On the other hand, a period of unemployment might be used to better prepare for self-employment, e.g. by acquiring new skills or developing market entry strategies. Apart from these individual-level duration effects, there are likely to be composition effects, as individuals with high motivation and ability can be expected to leave unemployment the fastest. Thus, with longer unemployment duration, a higher number of individuals with low ability and motivation could remain to found startups. In our study, we identify the overall causal effect of potential UI benefit duration on startup success and thus the (net) result of the government's UI policy. We rationalize which mechanisms could explain our results with the help of post-hoc analyses and a formalized job search model.

In this paper, we construct a dataset that links a representative panel survey of founders in Germany to administrative data on their own and their employees' labor market histories. Hence, we obtain a comprehensive linked employer-employee dataset for founders. Due to their high level of detail, German administrative data on labor market histories have been widely used in research (e.g. von Wachter and Bender, 2006; Dustmann et al., 2009), allowing for good comparability of our measures with those used in previous research in the context of transitions to dependent employment. Our data enable us to consider two types of outcome variables, founders' self-assessments, as measured by their motivation to start a business (necessitylopportunity-driven entrepreneurship), and their objectively measurable outcomes, such as sales and employment growth during the first years of business. We focus on startup growth as an outcome to allow for a clear attribution of the measured effects. Growth potential in the early years is a major predictor of firms' long-term success (Sedláček and Sterk, 2017) and should be more directly influenced by unemployment duration than more distant outcomes.

To identify the causal effects of unemployment benefit duration on startup success, we exploit exogenous variation through both policy reforms of PBD, and age-specific cutoffs in the PBD schedule for German unemployment insurance (UI). Our main empirical strategy is the Instrumental Variable (IV) approach. We instrument potential (and actual) unemployment benefit duration with the interaction term "being in the relevant age cohort" (only those above 45 years old were affected by reforms) and "becoming unemployed after the reform-changed maximum PBD". The reforms of 2006 and 2008 jointly reduced the maximum PBD by at least six months for affected cohorts. Our IV approach entails features of both Difference-in-Differences (DiD) 
and Regression Discontinuity Design (RDD) strategies. In general, the results remain robust when conducting an RDD to estimate the effect induced by age cutoffs in the PBD schedule or a DiD approach based on the policy reforms.

Our results reveal a negative overall causal effect of longer PBD on startup success. More specifically, our estimates suggest that longer PBD increases the actual unemployment duration of future founders, implying an UI duration elasticity of around 0.6. This estimate is higher compared to recent estimates suggested by literature focusing on dependent re-employment (e.g. Schmieder and von Wachter, 2016, find an elasticity of 0.15 for Germany). Via this channel of longer actual unemployment duration, longer PBD significantly increases the likelihood that individuals start firms out of necessity - compared to situations in which they start firms due to opportunity motives - by about two percent per month of PBD. Moreover, and foremost in the non-manufacturing sectors, we find consistent evidence for a negative effect of longer PBD on actual outcomes in terms of employment and sales growth in the first two years after starting up.

These overall causal effects of PBD can be driven by individual-level duration effects, composition effects, or a mix of both. We illustrate this situation using a stylized search model in Section 5. Empirically, we find limited evidence for composition effects in the observable characteristics of unemployed founders in response to UI policy changes. Hence, our findings suggest that the net effect is mostly driven by individual-level duration effects, i.e. the ability of individuals to succeed as entrepreneurs steadily decreases during unemployment spells. For instance, access to credit may deteriorate with longer unemployment duration and thus financially constrain the respective startups' growth potential. The results indicate that by setting the length of PBD, the government can affect the quality of firms started out of unemployment. Therefore, changes in PBD may induce considerable fiscal externalities (Lawson, 2017) affecting the costbenefit analysis of the UI system. Furthermore, the effect of PBD on startup success should also be considered when analyzing the value of UI for self-employment (cf. Hombert et al., 2020).

Our study makes three major contributions. First, we document how the PBD in the unemployment inusrance affects the actual unemployment duration for a future entrepreneur. In this context, it is ex-ante unclear whether the positive causal effect of PBD on actual UI benefit duration - which is usually found for those becoming re-employed as wage workers - also exists for those starting a business (and whether we should expect similar effect sizes). This question has direct implications for the cost of UI systems since, if it exists, additional fiscal externalities must then be considered due to transitions from unemployment to self-employment. 
Second, we provide evidence as to how the UI policy affects the motivation of founders, i.e. whether they start a firm due to a business opportunity or out of necessity (as a last resort). In this manner, our study illustrates how UI policies can serve as tools to maximize the share of opportunity-driven startups. These types of startups typically have the highest potential for generating long-term economic value (e.g. through innovation or growth). Our results further suggest that self-classifications in terms of motivation can serve as important indicators for the future potential of startups and are therefore worthy of attention in themselves.

Third, we facilitate an understanding of how the growth potential (success) of startups in terms of employment generation and sales depends on UI policy. This understanding is important for the optimal design of UI programs since it affects their cost-benefit ratios. There are also implications for the optimal design of active labor market policies which incentivize unemployed individuals to start a business, especially in terms of when such policies should be used. Thus, our results are informative for nascent entrepreneurs, money lenders, and policy makers.

With its research focus, our paper connects several strands of the literature on entrepreneurship and public economics which have thus far evolved in parallel to each other. First, research on entrepreneurship has investigated potential determinants for becoming a firm founder (e.g. Cagetti and De Nardi, 2006; Berglann et al., 2011; Levine and Rubinstein, 2017). Stylized facts suggest that unemployment increases the propensity to become self-employed (e.g. Evans and Leighton, 1990a,b; Meager, 1992; Blanchflower and Meyer, 1994; Kuhn and Schuetze, 2001; Andersson and Wadensjö, 2007; von Greiff, 2009; Røed and Skogstrøm, 2014a,b) but that previously unemployed founders perform more poorly in entrepreneurship than those transitioning from dependent employment (e.g. Andersson and Wadensjö, 2007). However, most of the entrepreneurship literature so far has treated previously unemployed founders as one group and largely ignored significant heterogeneity among the unemployed in terms of their unemployment durations, their motivations for starting a business and their firms' success. In addition, the issue of necessity-versus opportunity-driven entrepreneurship has only been discussed in the context of very specific active labor market policies (e.g. Caliendo and Künn, 2011; Caliendo and Kritikos, 2010, in the case of startup subsidies) but not in the more important context of the general UI system. In studying the effects of PBD on the timing involved in unemployed individuals moving (or being pushed) into self-employment (including its subsequent outcomes), we contribute to the entrepreneurship literature by providing evidence for the potential implications of the UI system on the success of firms started by unemployed individuals. 
Second, this project also adds to the literature on public economics in terms of the optimal design of unemployment insurance (UI) by providing evidence for the effect of PBD on future entrepreneurs. The public economics literature has discussed several aspects concerning the optimal design of UI policies, i.e. the level of benefits and their potential duration (e.g. Hopenhayn and Nicolini, 1997; Katz and Meyer, 1990a,b; Lalive et al., 2006; Lalive, 2008; Schmieder et al., 2012, 2016; Kolsrud et al., 2018). Its focus has been on investigating effects on subsequent employment outcomes, predominantly re-employment wages (e.g. Le Barbanchon, 2016; Schmieder et al., 2016; Le Barbanchon et al., 2019; Nekoei and Weber, 2017). Results suggest that increases in PBD lead to increases in actual unemployment duration. However, the effects of longer actual unemployment on re-employment wages remain disputed. For instance, Nekoei and Weber (2017) argue that longer PBD can either induce delays in job acceptance (and simply subsidize leisure) or improve job opportunities (through subsidizing a longer search that results in job matches of higher quality). While Nekoei and Weber (2017) find that the latter positive effect dominates in Austria, Schmieder et al. (2016) report negative effects of unemployment duration on re-employment wages in Germany. We contribute to this debate by providing evidence of the causal effect of unemployment benefit duration on self-employment outcomes based on our newly created dataset. Thus, our paper complements the analysis of UI benefits with respect to post-unemployment outcomes (Jarosch and Pilossoph, 2019).

We proceed as follows: in Section 2, we explain our dataset construction and conduct a descriptive analysis. Section 3 illustrates the institutional background and our identification strategies for deriving causal effects. In Section 4, we present our empirical estimates, which we rationalize in a stylized model in Section 5. Section 6 provides our conclusion.

\section{Data and Descriptive Analysis}

\subsection{Dataset}

For this paper's empirical analysis, we construct data that match the employer information provided in the IAB/ZEW Start-Up Panel with employee register data from the German Federal Employment Agency. In this way, we circumvent data limitations since German administrative social security employer-employee linked data normally do not contain any information on self-employed individuals. Unlike regular dependent employees, self-employed individuals in Germany are not obliged to contribute to the public social security system. 
The IAB/ZEW Start-Up Panel is a joint research project of the Institute for Employment Research of the German Federal Employment Agency (IAB), the Leibniz Centre for European Economic Research (ZEW), and Creditreform, Germany's largest credit rating agency (see Fryges et al., 2010, for details on the sample design of the dataset). The Start-Up Panel is a stratified random sample taken from the Mannheim Enterprise Panel ("MUP"), which contains basic information on almost all firms in Germany, including startups (Bersch et al., 2014). ${ }^{3}$ It provides comprehensive data on young firms from almost all industries (the primary sector, public sector and energy sector are excluded). Information is collected by means of a yearly telephone survey (computer-aided telephone interviews, CATI). The sample of the IAB/ZEW Start-Up Panel is stratified by the year of firm formation and by industry sector. Stratification is controlled for by including dummy variables for the stratification cells in all regressions. Currently, the IAB/ZEW Start-Up Panel contains data on more than 21,000 firms founded between 2005-2015. ${ }^{4}$

The linked register data are "Integrated Employment Biographies" provided by the German Federal Employment Agency. These administrative data yield information on the start and end dates of all employment and unemployment spells in the founders' (and the startup employees') employment histories and their potential unemployment benefit durations. The data are reported by the employing establishment, collected by the social insurance agencies, and processed by the employment agency. Due to their high level of detail, the data are widely used in scientific research (e.g. von Wachter and Bender, 2006; Dustmann et al., 2009; Schmieder et al., 2016).

We match the founders' and the startup employees' employment histories from the German Federal Employment Agency with the firm-level data from the IAB/ZEW Start-Up Panel with text search algorithm methods. Thus, we obtain the most representative employer-employee linked dataset for founders in Germany as of this date. Our matched dataset covers longitudinal information on approximately 18,000 startups. $^{5}$

\footnotetext{
${ }^{3}$ The underlying firm information is collected and provided by Creditreform, which maintains this data to conduct credit ratings for nearly all firms in Germany.

${ }^{4}$ The first survey wave was conducted in 2008 and collected data on firms founded between 2005 to 2007 . In the first years of data collection efforts, the Start-Up Panel dataset was financed jointly by ZEW, Creditreform and KfW bank, Germany's state-owned development bank, which administers a large part of the federal SME support programs in Germany. Therefore, the sample of startup cohorts until the year 2012 was also stratified by whether or not support was received from KfW. As for the other stratification criteria, sector and year of foundation, we control for these stratifications with dummy variables in all regressions as well.

${ }^{5}$ We could match labor market histories of about $80 \%$ of the founders from the IAB/ZEW Start-Up Panel based on their names, birth dates, and additional geographical information. Given that not all founders were employed, i.e. subject to social insurance in Germany previously (e.g. as they have always been self-employed), this is a very high ratio of matched individuals. Moreover, we were able to match establishment data to about $90 \%$ of those startups that self-reported (during an interview) employees subject to registration with the German social insurance based on the establishments' names and addresses. For details on the construction of our dataset, see Appendix B.
} 


\subsection{Descriptive Analysis}

For the aim of this study, we focus on the approximately 12,000 cases in which the firm was started by a single founder (as opposed to a team). We concentrate on single founders because our aim is to isolate the effects of individual unemployment duration on firm outcomes. Such an effect can be hardly identified for teams of founders, as e.g. only one of the founders might have been unemployed before starting up or all founders were unemployed but for different durations. Moreover, our dataset includes non-team founders that have and do not have employees. In the main empirical analysis, we focus on roughly 1,300 firms whose non-team-founders were unemployed directly before starting their firms. They were between 35 and 65 years of age when entering unemployment, and became unemployed before some major reforms led to changes in the availability of startup subsidies for the unemployed in 2012. We only include individuals for which all required information on control variables is available and who had collected enough contribution months to be entitled to receive benefits for the maximum PBD.

Detailed summary statistics for all variables are shown in Table 1, i.e. for our regression sample of previously unemployed founders, for those founders with above median unemployment duration as well as for a reference group of previously employed founders. The founders are typically male (85\%) and of German origin (94\%). They have on average 17 years of experience in the industry in which they started firms, and most of them $(85 \%)$ had never been self-employed prior to entering unemployment. The founders are, on average, 44.44 years old, and about $39 \%$ of them became unemployed when they were at least 45 years old (and hence belong to the treatment group in the subsequent causal analysis). In terms of education, $28 \%$ of founders achieved university degrees, and $13 \%$ of them held managerial positions in the five years before starting up. With, on average, a PBD of 12.32 months, their mean actual unemployment duration was 4.79 months prior to entering self-employment.

Figure 1 shows the outcomes in terms of employment and sales per year for all the (non-team) entrepreneurs in the relevant age range in the linked dataset. Figure 2 compares outcomes of all entrepreneurs in our sample, distinguishing those who started their business out of unemployment with those that became entrepreneurs without having been unemployed. ${ }^{6}$ The results show large differences between the two groups in terms of full-time equivalent (FTE) employment and

\footnotetext{
${ }^{6}$ As explained in Section 2.1 and in the footnotes accompanying the figures, we focus on non-team founders that are 35 to 65 years old. All firms are included, independent of the survival length. The graphs look almost identical when we condition on firms that survive at least three or five years, providing evidence that differences in growth measures are not driven by differences in survival. These graphs are available upon request.
} 
sales. Having been unemployed before starting a firm is associated with inferior outcomes as an entrepreneur from the very beginning and cannot be compensated for over the first seven years in business. After entering self-employment out of employment, founders start with average yearly sales of about 370,000 Euro and increase their yearly sales by an average of about 100,000 Euro over the first seven years in business. In contrast, founders who were previously unemployed start with sales of about 150,000 Euro a year and despite relatively stronger, concave-shaped sales growth over the first seven years in business, never come close to catching up (average yearly sales increase from about 150,000 to 300,000 Euro over the first seven years). Similarly, while founders coming out of unemployment show stronger relative employment growth in terms of FTE employment over the first seven years, they come never close to catching up with founders who were previously not unemployed (for unemployed founders: FTE employment increases from about 0.5 to 1.5 employees; for not unemployed founders: FTE employment increases from about 1 to 2 employees.).

Zooming in on those founders entering self-employment out of unemployment, Figure 3 compares the outcomes of the previously unemployed entrepreneurs in our sample, split at the median unemployment duration. The results show large differences between the two groups from the beginning that increase further over time in terms of both FTE employment and sales per year. Longer prior unemployment duration before starting a firm seems to be associated with inferior outcomes as an entrepreneur that are not yet visible to their full extent in the year of foundation but develop over the first years of a firm's existence. Hence, our descriptive results indicate that a large part of the outcome differentials between previously unemployed and not unemployed founders are driven by unemployed founders with long unemployment durations.

Besides sales and employment outcomes, our dataset also allows an assessment that comes closer to the roots of individual decision making and success by providing information on the founders' motives for starting up. During the first interview, i.e. closest possible to the date of startup to prevent bias, founders were asked to categorize their main motivation to start up the business. Table 2 shows how we categorize the motives for starting up into either necessity-driven or opportunity-driven. ${ }^{7}$ We classify the motives "self-determined working", the "realization of a business idea", as well as "better earning potential" as indicators of opportunity-driven

\footnotetext{
${ }^{7}$ Figure A.1 in Appendix A shows that necessity-driven founders start up more often just before UI benefits expire and thus appear to be pushed into self-employment. Table 1 shows that one third of previously unemployed non-team founders indicate that they were pushed into self-employment. Note that our notion of pushed entrepreneur also corresponds to its usage in Bianchi (2012). The observation of a spike just before exhausting UI benefits has been studied by Card et al. (2007) and recently been documented for Germany by DellaVigna et al. (2020).
} 
entrepreneurship. In contrast, we classify the motives "no suitable employment options" and "escape from unemployment" as indicators of necessity-driven or pushed entrepreneurship. ${ }^{8}$

Figure 4 compares outcomes of all non-team founders in our dataset, i.e. those with and those without a history of unemployment, split by their self-reported startup motivations (i.e. whether they classify as opportunity- or necessity-driven/pushed founders). The graphs reveal that founders who report an opportunity-driven motivation for starting their business experience faster growth in sales and FTE employment, suggesting that the motive for starting up is already a good predictor of subsequent startup success and that defining groups of entrepreneurs along the lines of their motivation seems adequate for describing observable differences in longerterm growth potential. Analogously, Figure 5 compares the same outcomes among just the previously unemployed founders in our main regression sample. Again, we find considerable differences between opportunity-driven and necessity-driven/pushed entrepreneurs in terms of FTE employment and sales. Starting a business out of unemployment with a necessity motivation is associated with poorer outcomes over the self-employment spell compared to launching a firm (out of unemployment) having been motivated by a business opportunity.

OLS regressions of being classified as necessity-driven (pushed) entrepreneur, of sales and of FTE employment (one and two years after having started the business) on the actual benefit duration (and numerous covariates) suggest that the graphically observed correlations are quite robust. The relationships revealed in the descriptive analysis (as discussed in the five figures above) remain significant in the OLS models even after controlling for individual labor market experience, education, gender, nationality, and year as well as industry fixed effects (see Table 3 for details on the industry classification). This simple regression analysis suggests that one additional month of actual unemployment duration is associated with a 1.7 percentage point increase in the likelihood of being pushed into entrepreneurship (see Table 4: five percent in relative terms, given an original basis of about $35 \%$ necessity-driven entrepreneurs). Moreover, one month of actual benefit duration is significantly correlated with a decrease in sales and FTE employment (Table 4). These results are reconfirmed when focusing on startups in nonmanufacturing sectors (75\% of our sample, see Table 5). Non-manufacturing sectors offer less restricted market entry due to lower initial investment requirements; thus, they are the most relevant for the entry of founders transitioning from unemployment to self-employment.

\footnotetext{
${ }^{8}$ Since the item "better earning potential" could be alternatively interpreted as pointing to a necessity motive, we double-checked all results by excluding founders who self-reported this motivation category. All results remain robust. Note that the surveyed persons could only select one answer category as their main motive for starting up.
} 
We conclude from our descriptive analyses that there is a statistically significant relationship between actual unemployment duration and subsequent self-employment outcomes in our data. In particular, starting a business out of unemployment is associated with poorer outcomes in terms of sales and employment when compared to businesses started by founders who have not been previously unemployed. Moreover, given a previous unemployment history, a longer duration of unemployment correlates with a necessity-driven motivation for starting up (or pushed entrepreneurship) and subsequently leads to poorer firm outcomes.

\section{Institutions and Empirical Strategy}

The goal of this paper is to find out whether PBD causally affects the actual unemployment duration for founders who start up out of unemployment and whether, in consequence, actual unemployment duration causally affects the motivation for starting a business out of unemployment as well as subsequent firm outcomes. The main identification challenges lie in the fact that an individual's potential and actual unemployment duration are likely to be non-random, which leads to endogeneity concerns. For instance, strategic behavior may be involved in becoming unemployed under the better PBD scheme conditions. Moreover, PBD (or actual unemployment duration) may be correlated with characteristics of unemployed people (e.g. previous working experience) that in fact explain the observed outcome. To solve these identification issues, we exploit policy reform- and an age cutoff-based exogenous variation in the PBD schedule within the German UI system.

We use an instrumental variables (IV) approach as our main estimation strategy and check the robustness of our results by further conducting a RDD and a DiD approach. These strategies allow us to derive the net causal effect of PBD on the actual UI duration elasticity of founders, the motivation to become self-employed, and objective measures of startup success. Therefore, we identify the overall effect of a change in the policy variable, $\mathrm{PBD}$, on entrepreneurial outcomes. Since PBD might affect entrepreneurial outcomes through either composition effects in the pool of unemployed individuals or individual-level duration effects, we try to disentangle both channels in post-hoc analyses. As a start, we explain the main institutional features the identification strategies rely upon. 


\subsection{Institutional Background: German UI System and Reforms}

In general, individuals in Germany who lose a job through no fault of their own are entitled to UI benefits ("Arbeitlosengeld I") if they satisfy certain eligibility constraints. These eligibility constraints require UI benefit claimants to have made social insurance contributions for at least 12 months within the two years (three years before February 2006) prior to becoming unemployed. The replacement rate is 60 percent of previous after-tax (net) earnings (67 percent if a person has dependent children) and has not changed since 1995. After exhausting UI benefits, an individual can obtain social security benefits tied to the existential minimum ("Arbeitslosengeld II"), which is subject to annual means testing. ${ }^{9}$

The PBD depends, first, on an individual's age at the start of the unemployment spell, and, second, on the number of months worked in jobs subject to social insurance contributions (contribution months) within a defined time period before claiming UI benefits (the coverage constraint was seven years prior to February 2006 and five years afterwards). For all workers satisfying the eligibility constraints, the PBD consists of a minimum of six months collected through at least the 12 contribution months in the time period just before the UI spell starts (Table 6). For each four additional contribution months before starting an UI spell, the PBD increases by two months. However, workers younger than 45 years are restricted to a maximum PBD of 12 months, which corresponds to 24 months of contributions, i.e. they cannot get more than 12 months of PBD if they have collected more than 24 contribution months. This maximum PBD cutoff increases with the age. For instance, before February 2006, for workers 45 and older at the start of their UI spell, 30 months of contribution led to 15 months of PBD (Table 6). Workers 57 and older could reach the maximum PBD of 32 months with 64 months of contributions. Hence, they could acquire 20 more months of PBD compared to a worker younger than 45 years who had also contributed 64 months before entering UI in the same month.

While the PBD schedule has remained stable for workers that enter UI at ages younger than 45, the maximum PBD cutoffs changed for individuals over 45 years in age in February 2006 and a second time in January 2008. Each reform affected those individuals entering UI after its implementation, whereas already unemployed individuals were still treated according to the rules in place in the month in which they entered UI.

\footnotetext{
${ }^{9}$ In line with our data analysis focusing on the years 2005-2015, we describe the German UI system as it has existed since 2005 in the main text. Appendix C.1 provides more details on the most important labor market reforms that took place in Germany during the early 2000s.
} 
Table 7 summarizes the eligibility criteria and changes resulting from the different reforms. ${ }^{10}$ The reform of 2006 led to a considerable reduction in the maximum PBD for those 45 years and older. The reform of 2008 led to a comparatively small (readjustment) increase in the maximum PBD for some age cohorts over 50 years. In total, the net reform effect when comparing the time period before February 2006 to that after January 2008 can be characterized by a reduction of at least six months in the maximum PBD for all age cohorts entering the UI system at 45 years and older (Table 7).

\subsection{Main Empirical Strategy: Instrumental Variable (IV) Strategy}

The identifying variation that we exploit in our three empirical estimation models stems from the age-dependent discontinuities in PBD (Table 6) and from the two reforms regarding the maximum PBD schedule which took place in 2006 and 2008 (Table 7). ${ }^{11}$ Our main empirical models follow the instrumental variable (IV) approach used in Le Barbanchon et al. (2019). The idea is to exploit the fact that the PBD in the German UI system depends on age-cut offs and that there have been reforms that changed the PBD but no other parameters, such as the UI benefit levels. Therefore, instrumenting PBD (or actual unemployment benefit duration) by an interaction between the reform and the age cutoff constitutes a valid instrument. It should introduce variation in benefit duration and satisfy the exclusion restriction because the differences in outcomes among individuals are unlikely to be explained by just small differentials in age (under or over the age cutoff) and the time at which individuals became unemployed (before or after the reform). We estimate IV models of the form:

$$
\begin{gathered}
y_{i t}=\alpha+\beta * \text { Treated }_{i t}+\gamma * P B D_{i t}+\delta * X_{i t}+\text { year }_{t}+\varepsilon_{i t} \\
y_{i t}=\alpha+\beta * \text { Treated }_{i t}+\gamma * A U D_{i t}+\delta * X_{i t}+\text { year }_{t}+\varepsilon_{i t}
\end{gathered}
$$

where, for each founder $i$ in month $t, y$ is the outcome variable which can be the motivation for starting a firm, logarithmized yearly sales in Euro in the first and in the second year after foundation, or the logarithmized FTE number of employees one year and two years after founda-

\footnotetext{
${ }^{10}$ For an overview of the reforms of the German UI benefit system before the time period studied in this paper, see Schmieder et al. (2012). For the time period studied in this paper, see Price (2019) and Appendix C.1.

${ }^{11}$ To the best of our knowledge, no startup subsidies in Germany depend on a founder's age. While there was a change in the scheme for startup subsidies in 2006, first, we also use the 2008 reform for identification when relying on reform-based variations in PBD, and second, the age-dependent discontinuities that we exploit for identification are independent of subsidy reforms. Thus, we are confident that our source of variation is not correlated to any changes occurring in startup subsidies for the unemployed (compare Appendix C.2). Moreover, we control for participation in subsidy schemes that are either governed by the German Federal Employment Agency or the KfW bank in all regressions and therefore account for all major startup subsidies in Germany.
} 
tion. Moreover, $\alpha$ is a constant, and $X$ is a vector of firm- and founder-specific control variables (education, managerial experience, self-employment experience, industry experience, gender, being subsidized, industry-fixed effects). Finally, we control for macroeconomic conditions and trends in the unemployment or self-employment rate by taking into account year-fixed effects. ${ }^{12}$

Depending on the model, the potential benefit duration $\left(P B D_{i t}\right)$ and the actual unemployment duration $\left(A U D_{i t}\right)$ are instrumented by the instrumental variables:

- IV06=After(02/2006)*Treated(age $\geq 45)$ which reflects the effect of a decrease in PBD by at least 6 months and/or

- IV08=After $(01 / 2008) *$ Treated $(50 \leq$ age $\leq 54)$ which reflects the effect of an increase in PBD by at least 3 months.

This set-up leads to the first-stage of the instrumental variable (IV) models:

$$
\begin{aligned}
& P B D_{i t}=\alpha+\beta * \text { Treated }_{i t}+\gamma * I V 06(+\gamma * I V 08)+\delta * X_{i t}+\text { year }_{t}+\varepsilon_{i t} \\
& A U D_{i t}=\alpha+\beta * \text { Treated }_{i t}+\gamma * I V 06(+\gamma * I V 08)+\delta * X_{i t}+\text { year }_{t}+\varepsilon_{i t}
\end{aligned}
$$

The first-stage models can be regarded as tests of the strength of our instrumental variables (see Table 10 to Table A.4). F-statistics from our first-stage models for PBD generally suggest that our instruments are very strong predictors of $P B D_{i t}$, with Equation (3) yielding high Fstatistics for the instruments, i.e. most F-statistic values are above 100 and never less than 10 in any specification. Moreover, one would expect the corresponding first-stage F-statistics to be smaller when instrumenting the actual employment duration $\left(A U D_{i t}\right.$ in Equation (4)). The IV should have a first-order correlation with the policy variable that changed due to the reforms (PBD) and only a second-order correlation with the actual unemployment duration. Consequently, when we use our IVs to instrument the actual unemployment duration — which we do in order to understand how changes in PBD affect subsequent outcomes of unemployed individuals in self-employment through changes in actual unemployment duration - the F-statistics are clearly smaller. However, they always remain above 10, which is the commonly used rule of thumb for F-statistics used to identify weak instruments.

Our IV estimator is best interpreted as the local average treatment effect of PBD or actual unemployment duration on our outcomes. This interpretation is similar to the interpretation of the IV approach used in Schmieder et al. (2016) for estimating the wage effect for unemployed individuals becoming re-employed as dependent employees. Our IV approach exploits both

\footnotetext{
${ }^{12}$ We tested taking out observations from January 2006 so that the year effects fully capture the after-reform dummy. Following this approach does not alter our results.
} 
reform- and age-cutoff-based exogenous variation in order to estimate the causal effect of PBD on actual unemployment duration, the motivation for starting a business, and on startup success. Nonetheless, we also present results from plain RDD and DiD estimation approaches as robustness checks. By estimating an RDD, we isolate the effects of exploiting only the age cutoffs in the PBD schedule to derive their local average treatment effect (see Section 4.2.1). By running a DiD strategy, we only rely on the reforms in the PBD schedule to estimate their average treatment effect (see Section 4.2.3). Since it unites the exogenous variation in the explanatory variable used in the RDD and DiD approaches, we argue that estimates from our IV strategy have higher external validity compared to estimates from plain RDD or DiD approaches.

\section{Results}

We begin by presenting OLS baseline estimates of the effect of our main explanatory variable, potential benefit duration (PBD), on the actual unemployment duration, on the motivation for starting a business, and on subsequent firm outcomes (see Table 8). In all regressions, we control for education, previous labor market experience, individual characteristics (gender, nationality), industry, and year-fixed effects. We also include dummy variables indicating whether founders received subsidies from the Federal Employment Agency and/or the KfW bank to control for any unobserved heterogeneity related to startup subsidies (see also Appendix C.2). The OLS results indicate that a one month increase in PBD comes with an increase in actual unemployment duration of 0.47 months. Hence, we estimate a duration elasticity of about 0.5 . Moreover, one month of additional PBD is associated with an increase in the probability of starting a business out of necessity by about two percentage points. Concerning firm outcomes, more PBD leads to fewer sales and FTE employment in the first two years after starting up. Turning to the coefficients of the control variables, more highly educated individuals tend to be less likely to start a business out of self-reported necessity. Previous managerial experience contributes to better performance in terms of sales and employment growth. Being female or a foreigner does not have any differential effect concerning actual unemployment duration or the motivation for starting a business. If at all, these two characteristics may be associated with lower sales growth.

We generally present results for all sectors, as well as results for just non-manufacturing sectors in this section (e.g. OLS baseline estimates for non-manufacturing firms are shown in Table 9). We do so since non-manufacturing sectors are of particular relevance for market entry by unemployed individuals because entry into these sectors usually requires comparably lower 
initial investment. Therefore, focusing on non-manufacturing sectors allows us to abstract from investment-driven unobserved heterogeneity. Importantly, our results for the full and restricted samples are fully consistent. Results obtained with the restricted non-manufacturing sample (about $75 \%$ of firms) are generally more precisely estimated.

\subsection{Main Results: Instrumental Variable (IV) Approach}

We present the results from our main IV models, as outlined in the methods Section 3, in Tables 10 and 11 as well as Tables 12 and 13. For these main results, we use "being treated by the policy reform of 2006" as an instrument for longer PBD and longer actual unemployment duration. Tables A.1 and A.2 as well as Tables A.3 and A.4 show results when using the two instrumental variables "being treated by the reform of 2006" and "being treated by the reform of 2008”.

The IV estimates suggest that longer PBD causally increases actual unemployment duration before individuals transfer from unemployment to self-employment. Prior research has confirmed this result only with respect to re-employment as a dependent worker. Via longer actual unemployment duration, longer PBD increases the probability that individuals start a company out of necessity (and not because they see a business opportunity). Subsequently, longer PBD leads to a decrease in firm performance in terms of employment and sales over the initial years in business. Turning to the effect sizes, according to our IV estimates, a one month increase in the PBD leads to a 0.6 month increase in the actual unemployment duration before starting up (column two of Table 10). Moreover, one additional month of PBD leads to a 1.5 percentage points higher probability of starting a firm out of necessity. Given that the average probability of starting a firm out of necessity is around 35 percent, this increase corresponds to a relative increase of four percent per month, which is economically significant (column three of Table 10). Concerning the effects on more objective outcomes, we find that only the effect on sales after two years remains statistically significant in the full sample in the IV setting. A one-month increase in the PBD leads to 7.2 percent lower sales in the second year. The effect of longer PBD on employment after two years is negative, as it was in the OLS models, but it is less precisely measured here. When focusing on the non-manufacturing sectors in Table 11, most effects become larger and more precisely estimated. They also reveal statistically significant negative effects of about one percentage point per additional month of PBD on FTE employment after the second year. The first-stage F-statistics are well above 150 in all versions of the IV models and indicate the very good predictive power of the instrument (Section 3.2). 
Our results are reconfirmed when using both IVs, that is, IV 06 for the 2006 reform, which decreased the PBD by at least six months, and IV 08 for the 2008 reform, which increased the PBD by three months. The results of changes in PBD on our outcomes of interest (Tables A.1 and A.2) remain very similar to those based on just the single instrument $I V 06$. The same is true when we focus on the non-manufacturing sectors (compare Table A.2 with Table 11). However, the quality of the first-stage model in terms of the F-statistic decreases through the inclusion of the additional instrument. Therefore, we present estimates with only one instrument (IV06) as main results. In summary, our IV results generally confirm the initial OLS results but are less precisely measured.

Finally, we repeat the IV estimation instrumenting actual unemployment duration (AUD) to establish a clear causal channel from PBD via actual unemployment duration to firm outcomes. The findings are shown in Tables 12 and A.3 when using only IVO6 as well when using IV06 and IV08 combined. Corresponding results for non-manufacturing sectors are provided in Tables 13 and A.4. While, as expected, the predictive quality of the first-stage models is lower than when instrumenting PBD, the results are fully in line with the previously described results for PBD and suggest that longer PBD affects startup motivation and outcomes via incentivizing longer actual unemployment duration.

\subsection{Robustness Checks: Two Further Estimation Strategies}

\subsubsection{Regression Discontinuity Design (RDD)}

The RDD exploits age-dependent discontinuities in the PBD through the equation:

$$
y_{i}=\alpha \mathbf{1}\left(\operatorname{age}_{i} \geq c\right)+f\left(\operatorname{age}_{i}, \boldsymbol{\beta}\right)+f\left(\operatorname{age}_{i}, \gamma\right) \times \mathbf{1}\left(\operatorname{age}_{i} \geq c\right)+X_{i}^{\prime} \delta+\varepsilon_{i},
$$

where $y_{i}$ is the outcome variable of interest, i.e. actual unemployment duration and subsequent performance as an entrepreneur. In addition, $X_{i}$ is the same set of individual-specific covariates as before (see Section 3.2), and $\varepsilon_{i}$ is an error term. The dummy variable, $\mathbf{1}\left(\right.$ age $\left.e_{i} \geq c\right)$, reveals whether individuals benefit from extended PBD because they become unemployed at an age above the age cutoff associated with the higher maximum PBD. Individual age is the forcing variable, for which we control with the $\beta$ coefficient reflecting its direct effect on $y_{i}$. Moreover, the $\gamma$ term reflects its indirect effect on $y_{i}$ via the interaction with the sharp age cutoffs. Consequently, $\alpha$ measures the pure discontinuity effect, i.e. the RDD estimate of interest, namely how PBD affects the outcomes of those who start a firm out of unemployment. 
In the RDD, we focus on the period from 2008 onward, an age range from 45 to 54 years old, and an age cutoff at 50. Below the age of 50, the maximum PBD is 12 months. Above 50, the maximum PBD is 15 months. Hence, a cutoff at 50 allows us to exploit an exogenous increase in the PBD of three months. Therefore, the identification assumption requires that there is no precise manipulation of the running variable around the cutoff, e.g. that workers do not plan to become strategically unemployed just after an age threshold is reached to exploit higher PBD (Lee and Lemieux, 2010). A comparable RDD approach has already been exploited to study re-employment outcomes (of dependent workers) for earlier reforms of the maximum PBD in Germany, see Schmieder et al. $(2012$, 2016). These authors show that the RDD approach delivers credible results for their time period studied (1987-2004). We apply a similar RDD for a more recent period (2003-2011) and with respect to a sample of individuals who transfer from unemployment to self-employment (i.e. not regular employment and who are therefore excluded in existing studies.). ${ }^{13}$

By restricting the regression sample to individuals who became unemployed after January 2008, we ensure that they all faced the same maximum PBD schedule, as shown in columns (6) and (7) in Table 6 or 7. As no other major labor market reforms occurred and startup subsidy schemes remained unchanged in the time period under study (cf. Appendix C.2), the only relevant variation in PBD is driven by the age cutoffs. We test this assumption by conducting a McCrary density test, which investigates whether there is bunching in the entry into self-employment from unemployment by workers becoming unemployed around the age cutoff (Imbens and Lemieux, 2008; McCrary, 2008). Results of the McCrary density test do not indicate significant discontinuity in the distribution of individuals entering unemployment around the cutoff age (Figure A.2). Hence, the McCrary test results suggest that the identification assumptions in our RDD model are satisfied.

\subsubsection{Regression Discontinuity Design (RDD) Results}

Results of the RDD are summarized in Figure A.3, Figure A.4, and Table A.5. Based on the age-dependent rules on the maximum PBD, as explained in Table 6 and Table 7, in the years since 2008, one would expect there to be an increase of around three months of PBD at the age of 50 for individuals who have contributed at least 30 months to social security. Indeed,

\footnotetext{
${ }^{13}$ Furthermore, Le Barbanchon (2016) shows that a similar RDD approach performs well in the context of analyzing a French reform that increased PBD for certain unemployed individuals. Nekoei and Weber (2017) conduct a similar RDD when estimating the effect of UI generosity on unemployment duration and re-employment wages in Austria.
} 
analyses of our sample show that the PBD increases, even though only by around 2.1 instead of 3 months (first panel in Figure A.3). Furthermore, as the second panel of Figure A.3 shows, according to our RDD strategy, the increase of 2.1 months in PBD translates into a significant increase in actual unemployment duration of about 1.2 months, suggesting a duration elasticity for unemployed individuals who eventually start a business of around 0.6, which is the same estimate that we obtained via the IV strategy. Unfortunately, the number of observations that can be used for the RDD is limited. Since information on sales is missing for a significant number of observations and sales are often highly volatile in the first years after a firm's foundation, we are only able to derive meaningful RDD results for employment outcomes after one year and after two years (Figure A.4). The RDD results suggest that an increase of about 2.1 months decreases FTE employment by about 12 percent in the first year and about 25 percent in the second year. Hence, an increase of one month in PBD leads to a reduction in FTE employment of about six percent in the first year and 12.5 percent in the second year after starting up.

In summary, the RDD results are consistent with those of the IV approach. Longer PBD leads to an increase in actual unemployment duration, which then leads to a decrease in subsequent startup success, as measured in terms of FTE employment.

\subsubsection{Difference-in-Differences (DiD) Approach}

The DiD approach exploits reform-induced changes in the PBD (similar to Cottier et al., 2019) with the equation:

$$
y_{i t}=\alpha+\beta * \text { Treated }_{i t}+\gamma * \text { After }_{t}+\delta *\left(\text { Treated }^{*} \text { After }\right)_{i t}+X_{i t}+\varepsilon_{i t},
$$

where $\alpha$ is a constant, $X_{i t}$ is a vector that includes the same set of person-specific controls as before (see Section 3.2), and $\varepsilon_{i t}$ is an error term for each individual $i$ in month $t$. Moreover, $\delta$ indicates the (causal) reform effect of PBD on our outcomes of interest $y$. Depending on the model version, $y$ is either the actual benefit duration, the motivation for starting up, or consists of subsequent outcomes for the self-employed. In the DiD setting, we exploit the 2006 reform. Thus, After $_{t}=1$ is a dummy indicating whether an individual becomes unemployed after February 2006. The treatment group consists of workers entering an UI spell at age 45 or above, whereas the control group consists of workers younger than 45 who claim UI benefits. The reform effect measures the treatment of reducing PBD by at least three months. 


\subsubsection{Difference-in-Differences (DiD) Results}

Our results for the DiD strategy are summarized in Table A.6. The first column in Table A.6 shows that the reduction of (depending on the contribution period prior to claiming benefits and on age) 3-14 months of PBD significantly reduces actual unemployment durations by, on average, around 3.6 months. This finding reconfirms the existence of a positive causal relationship between potential benefit and actual unemployment duration in our sample of founders starting up out of unemployment. The results for the remaining outcomes are not statistically significant in the DiD setting when we consider all sectors (columns 5/6 in Table A.6). Focusing on the non-manufacturing sectors, Table A.7 generally reconfirms our previous findings. As before, the effects now appear to be measured more precisely, and results indicate a significant increase in firm performance with respect to sales in the second year after starting up (due to the reduction in PBD). In summary, the DiD results appear to be consistent with our main findings that reducing PBD leads to a reduction in actual unemployment duration and to higher growth in terms of sales after two years of business activity. Note that the precision of the DiD estimates is comparably low, supposedly because we ignore information concerning how individuals are affected by the reform, which depends on their exact ages when becoming unemployed. Thus, the lower power is to be expected compared to that for our IV setting.

\subsection{Discussion of Results and Mechanisms}

Our empirical results based on three different estimation methods, i.e. IV, RDD, DiD, suggest a number of conclusions. First, longer PBD increases actual UI duration for those unemployed individuals who end unemployment by starting a firm. Hence, our results document that what prior literature has established for individuals transitioning from unemployment to dependent employment (e.g. Schmieder and von Wachter, 2016) also holds for individuals transitioning from unemployment to self-employment. In terms of size, our estimated duration elasticity is around $0.6^{14}$ and thus a bit higher than what recent estimates focusing on transitions from unemployment to paid employment suggest. Focusing on transitions from unemployment to paid employment, Le Barbanchon et al. (2019) report a duration elasticity of 0.3 for France, Nekoei and Weber (2017) report a duration elasticity of 0.016 for Austria, and Schmieder et al. (2016) find a duration elasticity of 0.15 for Germany (in the period prior to 2004). Although these

\footnotetext{
${ }^{14}$ For the OLS regression, we find a duration elasticity of about 0.5 ; for the IV and the RDD strategies, we obtain a duration elasticity of around 0.6; for the DiD strategy, we achieve a duration elasticity of around 0.7 . We consider these estimates to be very similar to each other given that differences in results across the different estimation strategies are to be expected. The RDD measures a local average treatment effect, whereas the DiD derives the average treatment effect. Our IV strategy can be intuitively understood as a compromise that unites RDD and DiD elements. Thus, we expect our IV results to be in between RDD and DiD.
} 
studies analyze increases in PBD, in a setting like ours, where UI generosity decreases, Doris et al. (2018) find larger effects. Furthermore, Doris et al. (2018) provide an overview of over 18 studies that estimate the UI duration elasticity with respect to transitions to paid employment and report a median duration elasticity of 0.53 (cf. Appendix, Table 2 in Doris et al., 2018). Hence, our estimate of a duration elasticity of 0.6 for those transitioning from unemployment to self-employment seems to be in reasonable range and somewhat higher than what has been found for those transitioning to paid employment. ${ }^{15}$

Second, longer PBD (via longer actual unemployment duration) increases the fraction of pushed entrepreneurs. More unemployed individuals seem to literally escape unemployment by becoming self-employed out of self-reported necessity rather than opportunity-driven motivation. Finally, we find overall consistent, but not always precisely measured, evidence that longer PBD and longer actual unemployment duration reduce the subsequent success of firms that are started out of unemployment (in terms of sales and employment growth).

The estimated effects of longer PBD on startup motivation and success can be driven by different mechanisms. On the one hand, longer PBD can be expected to change the behavior of unemployed individuals, thereby leading to a different composition of founders who decide to start a firm out of unemployment (composition effect). On the other hand, by incentivizing longer actual unemployment duration, longer PBD could alter the success potential at the individual level (individual-level duration effect). Individual-level duration effects can arise, for instance, because of stigmatization, a loss of professional networks, or depreciation of skills and knowledge during an unemployment spell. In addition to these direct negative effects on startup performance, individual-level duration effects can also financially constrain the growth potential of firms started out of unemployment by rationing access to credit (in line with the recent findings of, e.g. Caliendo et al., 2019).

We attempt to assess the potential influence of both mechanisms by analyzing changes in the composition of our sample of previously unemployed founders over time and compare them to changes in the composition of a reference group of previously not unemployed founders. We focus on comparing the two groups across two points in time, namely, before and after the UI reform of 2006 (our main source of exogenous variation in PBD). In Table 14, we provide t-tests for the before/after reform comparisons of our main explanatory variables and an additional

\footnotetext{
${ }^{15}$ Our findings might additionally suggest that the translation from potential into actual unemployment duration may be stronger with respect to reductions than increases in the PBD.
} 
broader indicator of founder quality: the average daily employment wage within five years before starting up (capped at the social security contribution ceiling). We add this measure to assess the potential influence of unobserved factors that we do not control for in our models.

Looking at all unemployed founders in our regression sample who are in the age-based treatment group (two left panels), we observe almost no significant changes in composition before or after the reform. Consistent with the reform and our estimation results, the average actual unemployment duration of treated founders increases significantly. Moreover, significantly more founders receive subsidies from the Federal Employment Agency in the period after the reform (we control for these subsidies in our regressions). Most notably, the (statistically) insignificant but sizable increase in the average pre-unemployment wage for founders after the reform is in line with a composition mechanism of "better" founders due to lower PBD. In addition, the fact that we also find smaller effect sizes for the reference group of founders who were not previously unemployed (right panels in Table 14) points towards the possibility that composition effects are induced by the reform. Overall, given the modest observable differences in composition, composition effects seem to partially explain our results but are unlikely to be their main driver.

This assessment is supported by two further checks. First, we re-estimate our main OLS and IV models without any control variables (see Tables A.8 and A.9 as well as Tables A.10 and A.11), which allows us to assess whether including covariates, which should substantially reduce the impact of the composition effects, affect our point estimates for changes in PBD. When estimated without control variables, all point estimates for changes in PBD or actual unemployment duration remain very similar. Hence, the test does not suggest strong reform-induced composition changes in the group of unemployed founders are driving our results. This interpretation is also in line with the reduction in, but not loss of, statistical significance when moving from OLS to IV estimation. Second, our assessment is supported by the sample/reference group summary statistics in Table 1. Differences in human capital between unemployed founders and the reference group of previously employed founders seem more sizeable than the small differences between all unemployed founders and unemployed founders with unemployment durations above the median. Hence, it is unlikely that composition changes over the unemployment duration explain our regression results. ${ }^{16}$

\footnotetext{
${ }^{16}$ This conclusion also corresponds to earlier findings of Farber et al. (2015), who show that UI extensions in the US in response to the Great Recession did not have sizeable effects on recipients' job-finding rates and labor force participation, hence suggesting that the extensive margin of the UI extensions, which might lead to composition changes, is rather negligible.
} 
In summary, our data indicate the existence of both composition and individual-level duration effects that are induced by the UI policy reforms. Of the two, our results suggest that reforminduced individual-level duration effects could be the main mechanism behind the estimated effects of longer PBD on startup success. However, future research should investigate the mechanisms in more detail and quantify the relative importance of composition versus individuallevel duration effects.

\section{Stylized Theoretical Model}

In the following section, we present a stylized model to rationalize the empirical findings that we observed in the previous Section 4. We conclude this section by discussing the policy options in the model (Section 5.2), implications in terms of fiscal externalities (Section 5.3), and general policy implications of our findings (Section 5.4).

\subsection{The Framework}

We consider workers who become unemployed in period $t=0$, provided they remain unemployed and receive UI benefits for duration $d .{ }^{17}$ In each time period (month), they receive unemployment benefits $b_{t}$ until the maximal potential unemployment benefit duration $P B D$ is reached (cf. Section 3.1). Focusing on the case of a two-layer UI system, benefits can be defined as $b_{t}=\bar{b}$ for $t \leq P B D$, where $\bar{b}$ is the constant UI benefit level which the unemployed individual receives for the entire UI spell (until exhausting benefits at the PBD). The UI benefits received depend on the previous wage, i.e. they constitute the replacement rate fraction of the average monthly wage income over the six months before becoming unemployed. Next, $b_{t}=\tilde{b}<\bar{b}$ for $t>P B D$, where $\tilde{b}$ can be interpreted as Germany's existential minimum assistance "Arbeitslosengeld II", which is independent of previous contribution months and lower than the wage-dependent UI benefits $(\bar{b})$. Without loss of generality, this amount is the same for all eligible claimants. ${ }^{18} \mathrm{We}$ assume that each individual has a latent ability (including entrepreneurial ability) $\theta \sim G(\theta)$, where $G($ ) is a normal density function. Then in each time period, an unemployed individual has to decide

\footnotetext{
${ }^{17}$ The model is in continuous time, and the horizon for each worker lasts until retirement time $T$. Moreover, we consider them to be risk-neutral.

${ }^{18}$ Note that the replacement rate for UI benefits $(\bar{b})$ is $60 \%$ for single individuals and $67 \%$ for individuals with dependent children. When receiving the existential minimum $(\tilde{b})$, the additional amount received per child on top of the basic minimum corresponds approximately to the general child allowances every parent receives from the German federal state ("Kindergeld"). Thus, the relative drop in income when exhausting UI benefits does not vary much per person independent of the family structure, and we abstract from this issue for the purpose of this chapter.
} 
whether to search for employment or to start a firm, i.e. to become self-employed. Let $V_{u}^{e}$ be the value function of an unemployed individual searching for employment and $V_{u}^{s e}$ be the value function of an unemployed individual starting a business. Then the decision of an unemployed individual is characterized by the value function:

$$
V_{t}^{u}=\max \left\{V_{u, t}^{e}, V_{u, t}^{s e}\right\}
$$

Value of Searching for Employment out of Unemployment Ignoring savings (workers live hand-to-mouth), the value of searching for employment when an individual is unemployed can be characterized by:

$$
\begin{aligned}
& V_{u, t}^{e}=b_{t}-\psi_{t}\left(s_{t}\right)+ \\
& \quad \beta\left\{p_{t}\left[1-F\left(\phi_{t}\right)\right] \int_{\phi_{t}}^{\infty} V_{t+1}^{e}\left(w_{t+1}\right) d F\left(w_{t+1}\right)+\left[p_{t} F\left(\phi_{t}\right)+\left(1-p_{t}\right)\right] V_{t+1}^{u}\right\}
\end{aligned}
$$

An unemployed individual receives consumption flow utility from benefits $c_{u, t}=b_{t}{ }^{19}$ but faces search costs $\psi_{t}$, which, in line with the literature (e.g. Schmieder and von Wachter, 2016), are assumed to be a differentiable, increasing, and convex function of search effort $s_{t}$. With probability $p_{t}=p\left(s_{t}, \theta\right)$, which depends on search efforts and ability, the unemployed worker receives a job offer for period $t+1$. Note that in this setting, the individual's optimal behavior is characterized by a reservation wage $\phi_{t}$, above which any wage offer $w_{t} \geq \phi_{t}$ is accepted. ${ }^{20}$

Thus, with probability $1-F\left(\phi_{t}\right)$, the offer is accepted and the individual becomes reemployed, receiving the corresponding expected value of being employed, i.e. $V_{t+1}^{e}$ (see Equation (9)). However, with probability $F\left(\phi_{t}\right)$, the offer is too low and is rejected. In this case and if the worker receives no other offer (with probability $1-p_{t}$ ), s/he remains unemployed in the next month and receives the next period value of being in unemployment, i.e. $V_{t+1}^{u}$ (Equation (7)). As usual, $\beta$ is the discount factor for future period returns. ${ }^{21}$ The two-layer UI system implies through the parameter $b_{t}$ that if an individual stays unemployed, surpassing the PBD, the outside option will decline to the existential minimum (from $b_{t}=\bar{b}$ to $b_{t}=\tilde{b}<\bar{b}$ ). Thus, a drop in the value function $\left(V_{u, t}^{e}\right)$ is to be expected in the month when the maximum $P B D$ is reached.

\footnotetext{
${ }^{19}$ Note that $c_{u, t}=b_{t}+y_{u}$, where $y_{u}$ could be income from other sources that, if assumed to remain constant over the UI spell and exogenously given, would not alter our qualitative conclusions (e.g. support from family members).

${ }^{20}$ Note that the cumulative distribution function $F()$ may depend on the duration of unemployment, for instance, due to depreciation in human capital, (statistical) discrimination, or stigma effects, as explained in Jarosch and Pilossoph (2019) and suggested by the experimental evidence in Oberholzer-Gee (2008).

${ }^{21}$ One could introduce myopic behavior on the part of agents by changing the discount factor. We abstract from this complication, as we have no empirical evidence that irrational behavior is driving our results.
} 
The Value of Being in Employment is then characterized by:

$$
V_{t}^{e}=\left(w_{t}-\tau\right)+\beta\left\{\lambda_{t} V_{t+1}^{u}+\left(1-\lambda_{t}\right) V_{t+1}^{e}\right\}
$$

An employed worker receives consumption flow utility $c_{e, t}=w_{t}-\tau$, i.e. consumption based on the net wage. ${ }^{22}$ Variable $\lambda_{t}$ is an exogenous separation rate that may vary depending on macroeconomic conditions over time. Thus, with probability $\lambda_{t}$, the worker may lose his/her job and become unemployed again, but, with probability $1-\lambda_{t}$, the worker remains employed. As a simplifying restriction, we ignore the option of moving from employment to self-employment but focus on flows from unemployment to self-employment, as this resembles our available empirical setting and is the relevant labor market flow we study.

Value of Entering Self-Employment out of Unemployment The value for an unemployed individual becoming self-employed out of unemployment is characterized by:

$$
\begin{aligned}
& V_{u, t}^{s e}=b_{t}-\psi_{t}^{s e}\left(s_{t}, \theta\right)+ \\
& \quad \beta\left\{p_{t}\left[1-F\left(\phi_{t}\right)\right] \int_{\phi_{t}}^{\infty} V_{t+1}^{s e}\left(\pi_{t+1}\right) d F\left(\pi_{t+1}\right)+\left[p_{t} F\left(\phi_{t}\right)+\left(1-p_{t}\right)\right] V_{t+1}^{u}\right\}
\end{aligned}
$$

An unemployed individual evaluating whether to become self-employed faces a value function similar to that of an individual searching for employment Equation (8). Again, the individual has a consumption flow utility in the form of unemployment benefits $b_{t}$ and faces search costs $\psi_{t}^{s e}\left(s_{t} \theta\right)$. We expect these search costs to be different from, and more dependent on individual ability than, those costs incurred when searching for employment since an individual has to develop an idea, do market research, and find capital instead of writing applications during the more standardized process of looking for paid employment. In other words, becoming self-employed depends more on an individual's skills $\theta$. The higher the ability, the smaller are market-entry search costs. The unemployed individual still faces a reservation wage $\phi_{t}$, above which potential profits from self-employment would be accepted. However, if the potential profit is too low, the individual may remain unemployed and continue to look for employment. Otherwise, if self-employment profits are higher than the reservation wage $\pi_{t} \geq \phi_{t}$, the individual will prefer to form a startup.

\footnotetext{
${ }^{22}$ Taxes could be also designed to be proportional taxes $(1-t)$ without changing the qualitative results.
} 
Value of Being in Self-Employment The value of being in self-employment can be characterized by the following value function:

$$
V_{u t}^{s e}=\pi_{t}(\theta)+s u b_{t}+\beta\left\{\gamma(\theta) V_{t+1}^{u}+(1-\gamma(\theta)) V_{t+1}^{s e}\right\}
$$

A self-employed person earns profits $\pi_{t}(\theta)$ (net of the startup costs and taxes in the case of positive profits) and may receive a subsidy $s u b_{t}$. Therefore, the returns $\pi_{t}(\theta)$ are assumed to increase with entrepreneurial skills $\left(\frac{\partial \pi_{t}()}{\partial \theta}>0\right)$, reflecting, e.g. that the quality of successful business ideas may increase with $\theta$. Similarly, the probability that the startup fails, $\gamma(\theta)$, is assumed to decrease as ability increases, $\frac{\partial \gamma()}{\partial \theta}<0$, reflecting, e.g. that better business ideas are less likely to result in failure. Thus, with probability $(1-\gamma(\theta))$, the startup will survive. With probability $\gamma(\theta)$, the founder has to return to unemployment, $V_{t+1}^{u}$ Equation (7).

The Effect of Unemployment Duration on Value Functions The unemployed worker's decision problem Equation (7) involves maximizing the expected utility between the value of moving from unemployment to employment and the value of becoming self-employed out of unemployment. See Appendix D.1 for the derivation of the results.

First, the value function for moving from unemployment to employment can be characterized by Equation (8), where $V_{t+1}^{e}$ is characterized by Equation (9). It is important to note that given a fixed level of (entrepreneurial) ability $\theta$, the value function $V_{u, t}^{e}$ features negative duration dependence $\frac{\partial V_{u t}^{e}}{\partial d} \mid \theta<0$. There are two main sources of UI duration dependence: the search effort may vary over the unemployment duration, and, over time, benefit levels decrease (reaching PBD at least once with the drop to the existential minimum). ${ }^{23}$ The accepted job offer's value depends on both the search effort, which determines the job offer arrival rate $p\left(s_{t}, \boldsymbol{\theta}\right)$, and the re-employment wage.

We derive the optimal search intensity and reservation wage paths in order to observe how these variables react to an increase in $d=P B D$. We find that the reservation wage is positively correlated with the potential unemployment benefit duration, i.e. $\frac{\partial \phi_{t}}{\partial d}>0$. The search intensity reacts negatively to an increase in $\mathrm{PBD}$, i.e. $\frac{\partial s_{t}}{\partial d}<0$. Hence, an individual will prefer to stay unemployed longer when the PBD is increased. This effect of PBD on actual unemployment

\footnotetext{
${ }^{23}$ Nekoei and Weber (2017) show that a directed search model incorporates these two sources of duration dependence and includes the random search McCall-style model that we present as a special case. Moreover, they reveal that selectivity may be positively, and duration dependence negatively, affecting re-employment wages. Burdett et al. (2020) build a structural model that reproduces negative wage effects following a job loss and suggest that foregone human capital accumulation is the main source of their persistent drain on post-unemployment earnings.
} 
duration, which can be rationalized by negative duration dependence $\left(\frac{\partial V_{u t}^{e}}{\partial d} \mid \theta<0\right)$, has been shown to be an empirically robust finding, even if there is not yet a consensus concerning the welfare implications for post-unemployment wages (e.g. Schmieder et al., 2016; Schmieder and von Wachter, 2016; Nekoei and Weber, 2017). ${ }^{24}$

Second, the value function of moving from unemployment to self-employment can be characterized by Equation (10), where $V_{t+1}^{s e}$ is characterized by Equation (11). Holding (entrepreneurial) ability fixed, this value function is also dependent on unemployment duration $d$, i.e. $\frac{\partial V_{u t}^{s e}}{\partial d} \mid \theta<0$. However, in absolute terms, it is smaller than $\frac{\partial V_{u t}^{e}}{\partial d}$, i.e. $\frac{\partial V_{u t}^{e}}{\partial d}\left|\theta<\frac{\partial V_{u t}^{s e}}{\partial d}\right| \theta<0$. We derive this fact by exploiting the definitions of $V_{u, t}^{e}$ and $V_{u, t}^{s e}$. By assuming that the value of leaving unemployment in the next period depends, on average, on the present value of the reservation wage, we can write $V_{u, t+1}^{e}=\frac{1}{\rho} \phi_{t}$. In the case of self-employment, the latter definition has to be extended to $V_{t+1}^{s e}=\frac{1-\gamma(\theta)}{\rho} \phi_{t}$ because self-employment can only be realized with probability $[1-\gamma(\theta)]$

Having derived the optimal reservation wage and search intensity paths, we document that the optimal search intensity for business opportunities is less dependent on unemployment duration $d$ than in the case of searching for regular employment. Thus, the negative unemployment duration dependence for becoming self-employed is smaller than that for searching for employment, reflecting the idea that self-employment can be interpreted as an alternative professional activity that is more dependent on an individual's skills than on the labor market conditions and thus less dependent on unemployment duration (compare Appendix D.1). Moreover, the search process for self-employment is different from the search for regular employment. Now, it is possible to rationalize our empirical results by analyzing qualitatively how the value functions for becoming employed $V_{u t}^{e}$ (Equation (8)) and self-employed $V_{u t}^{s e}$ (Equation (10)) evolve with unemployment duration $d$ and how these evolutions influence an unemployed individual's decision, given his/her (entrepreneurial) ability. Figure 6 illustrates that the unemployed individual will prefer to find a job when the value function for searching for employment $V_{u t}^{e}$ is above the value function for becoming self-employed $V_{u t}^{s e}$. Whereas, the individual will prefer to start a business when $V_{u t}^{s e}>V_{u t}^{e} \mid \theta$. The red line depicts $\frac{\partial V_{u t}^{e}}{\partial d} \mid \theta<0$. The blue line shows $\frac{\partial V_{u t}^{e}}{\partial d}\left|\theta<\frac{\partial V_{u t}^{s e}}{\partial d}\right| \theta<0$. Moreover,

\footnotetext{
${ }^{24}$ Note that there have been different theories proposed to explain this finding. These theories include human capital or job-specific skills decaying over unemployment spells and statistical discrimination, which assumes that individuals who are less capable remain unemployed for longer periods. Additionally, stock-flow matching could also explain duration dependence, as it implies that those entering unemployment and not finding a job match quickly become increasingly dependent on the inflow of newly posted vacancies (note that flow variables are quantitatively smaller than stock variables).
} 
the vertical black line marks the PBD; at this point in the unemployment duration, the red line drops by $x=\bar{b}-\tilde{b}$ because UI benefits $\bar{b}$ drop to the existential minimum $\tilde{b}$ (cf. Appendix C). Thus, the stylized model suggests that PBD can determine the composition of the group of self-employed individuals who transition from unemployment, which becomes apparent when analyzing how unemployed individuals behave in this model.

First of all, by holding all else fixed as (entrepreneurial) ability changes, we can observe the following. As Figure 7 illustrates, some high-ability individuals may always decide to become self-employed once unemployed, i.e. once they must search for a new post-unemployment labor market status. Correspondingly, Figure 8 shows that certain low-skilled unemployed individuals would never decide to become self-employed but rather would continue to search for employment. Note that these individuals have been employees and, after becoming unemployed, start to consider self-employment as an alternative to re-employment. Thus, they may only start to think about their entrepreneurial abilities once they become unemployed.

As Figure 9 illustrates, our model explains how the government can influence the composition of the group of unemployed individuals who decide to become self-employed out of unemployment via setting the PBD. Note that a minimum PBD is needed for even highly entrepreneurial types to have enough time to prepare the transition from unemployment to self-employment. Beyond that, however, the longer an individual is unemployed before moving to self-employment, the lower his/her $V_{u t}^{s e}$ and thus the lower his/her subsequent firm's performance appears to be (i.e. the composition changes). Moreover, if we considered negative individual-level duration effects to be the main response to a longer actual unemployment duration (that was induced through longer PBD), we would reach similar qualitative conclusions. In other words, composition and individual-level duration effects or a mixture of both, would be in line with the empirical evidence that PBD positively affects actual benefit duration and, through the latter, negatively affects the motivation to become self-employed as well as subsequent startup success.

Finally, as Figure 10 shows, our model can also rationalize our results for the case in which unemployment duration would not also harm potential self-employment outcomes, i.e. in the case of zero UI duration dependence for self-employment outcomes. Then, the empirical result of the subsequent startup success declining as the unemployment duration of a founder increases can also be rationalized with a horizontal value function $V_{u}^{s e}$ that is independent of $d$. To summarize, Figure 11 demonstrates that the government can change startup success by setting the PBD. 


\subsection{Further Policy Options in the Model}

Early Re-training for Employment Figure 12 shows that, given the same maximal PBD, early re-training can reduce the rate at which $V_{u}^{e}$ declines with actual unemployment duration. Thus, for a fixed PBD, retraining may improve welfare, thus maintaining consumption smoothing and general matching considerations for unemployment to employment transitions. This could reduce the number of necessity founders via slowing the negative UI duration dependence in $V_{u}^{e}$ that is itself causally influenced by PBD.

Subsidies for Self-Employment As Figure 13 illustrates, subsidies targeted at unemployed workers who may have revealed some entrepreneurial skills, e.g. via a business plan, would increase $V_{u}^{s}$ and thus the post-unemployment startup success probability. Hence, subsidies could make it easier for unemployed individuals with promising ideas to stop searching for employment and focus on preparing their startup, consequently reducing their time period in unemployment (and hence, the fiscal externality; see next paragraph). ${ }^{25}$

\subsection{Implications for Fiscal Externality}

When thinking about optimal UI benefit duration, the social costs of changing the PBD must be taken into account, which is the so-called fiscal externality it creates (Lawson, 2017). That is, in the spirit of the Baily-Chetty framework (e.g. Chetty, 2009; Kroft and Notowidigdo, 2016), the optimal UI benefit duration should balance the welfare benefits created by additional insurance, which help to smooth overall consumption, with the social costs of extending PBD. The latter is captured by the fiscal externality (i.e. the effect on the government's budget).

To illustrate the role of taking self-employment out of unemployment into account, let us consider an example. In a worker's last pre-unemployment job, s/he earned wage $w$ and paid taxes $\tau .^{26}$ The worker enters unemployment in time period $T_{0}$. In line with our results, extending the PBD would induce longer actual unemployment of $\left(T-T_{0}\right)$ periods. In time period $T$, the unemployed individual becomes self-employed. Especially, if the individual becomes a necessity entrepreneur who actually does not want to become self-employed but only starts a firm to escape unemployment, their profits $\pi_{s}$ might be lower than their pre-unemployment wage $w$ (as

\footnotetext{
${ }^{25}$ Early training for self-employment (relaxing the assumption of entrepreneurial types such that some skills can be developed through external support) could increase $V_{u}^{s}$. Thus, the post-unemployment startup success probability could be increased, e.g. by coaching founders in setting up better business plans.

${ }^{26}$ Without loss of generality, we just consider proportional taxes and follow Lawson (2017) in assuming that the fiscal externality of social security programs works through labor income taxes.
} 
a proxy for the hypothetical re-employment wage) during their self-employment spell (lasting from period $T+1$ until time period $S$ ). If, in addition, the (necessity) entrepreneur fails at time $S$ and drops back into unemployment from time $S+1$ onward, there would be forgone tax revenues $\left(\tau \pi_{s}\right)$ and the benefits paid during unemployment $(b)$ to consider. Formalizing the example, we arrive at a formula for fiscal externality:

$$
\text { FiscalExternality }=(\tau w+b)\left(T-T_{0}\right)+\sum_{\boldsymbol{s}=\boldsymbol{T}+\mathbf{1}}^{\boldsymbol{S}} \tau\left(\boldsymbol{w}-\boldsymbol{\pi}_{\boldsymbol{s}}\right)+\sum_{\boldsymbol{s}=\boldsymbol{S}+\mathbf{1}}\left(\tau \boldsymbol{\pi}_{\boldsymbol{s}}+\boldsymbol{b}\right) \boldsymbol{D}_{\boldsymbol{s}}
$$

The first term is the standard duration effect, which imposes a negative fiscal externality in the case of limited UI duration. In fact, longer unemployment duration implies that the government forgoes potential tax revenue $(\tau w)$ and also has to pay for the unemployment insurance expenditures $b$ over the course of the worker's unemployment spell. By increasing PBD, the negative fiscal externality would increase, not only for those who then become employed (Schmieder et al., 2016) but also for those who start a business out of unemployment, as shown earlier, because, in both cases, the PBD is positively linked to actual unemployment duration.

The second term takes into account the effect of unemployment insurance on self-employment performance in terms of the government's budget. In the given example, when the profits from self-employed are below pre-unemployment wages $\left(\pi_{s}<w\right)$ [as a proxy for the hypothetical re-employment wage], the negative fiscal externality would increase. ${ }^{27}$ However, in theory, this term could also decrease the overall negative fiscal externality if $\pi_{s}>w$, which might most likely be the case for opportunity entrepreneurs who have good business plans and might be better off than they were with pre-unemployment wages or would be under other re-employment options. ${ }^{28}$

The last term expresses the extra cost incurred if the self-employed fails and the individual subsequently (for a period $D_{s}$ ) returns to unemployment. In that case, a second-order duration effect consisting of forgone tax revenue and potential benefit payments could further increase the fiscal externality.

In summary, taking the effect of longer PBD on self-employment performance into account may change the overall fiscal externality of UI, which, in turn, could alter optimal UI considerations. For instance, if PBD pushed many unemployed individuals into necessity entrepreneurship and doing so caused the negative fiscal externality to grow, as in the given example, a decrease in

\footnotetext{
${ }^{27}$ Note that this case is plausible even at low income levels. Regular wages are usually bound by minimum wages, whereas the corresponding earnings from self-employment have no lower bound.

${ }^{28}$ In fact, if these positive effects were to dominate, this situation would correspond to the positive UI wage effect, as suggested by Nekoei and Weber (2017), for those who start a business instead of finding re-employment.
} 
optimal PBD may be implied. Given that the literature on optimal UI usually considers just the transition from unemployment into paid employment, ignoring transitions into self-employment, if such transitions are considered at all, implies that only the first standard duration term in Equation (12) is taken into account. Thus, it is important to consider the impact of PBD on self-employment and the associated fiscal externality when it comes to the optimal UI design.

\subsection{Policy Implications}

First, our results have implications for the design of an optimal UI policy. The previous Section 5.3 shows that longer PBD may increase the fiscal externality through its effect on self-employment performance. By omitting the possibility that unemployed individuals can also choose to enter self-employment instead of dependent employment, the literature and politics have neglected this effect. Too much selection into self-employment due to necessity after a long unemployment duration may, however, imply high social costs. Thus, the UI system should design optimal PBD in such a way that considers both transitions to dependent employment and to self-employment, as well as their outcomes. Moreover, our findings can improve insights into the so-called value of non-employment, which is important for the results of many wage-bargaining models (Jäger et al., 2019).

Second, since economic trends induced by digitization and the popularity of policy tools that promote startup activity to pave the way out of economic crises may lead to more startups in the future, thinking about the design of social safety nets, particularly with respect to unemployment insurance for self-employed individuals, may become increasingly relevant. Moreover, the results for Germany, with a low overall unemployment rate, might be rather lower bound estimates. Thus, this paper shifts its attention to an important discussion of how one should best design social safety nets for self-employed individuals.

Finally, the findings in our paper may also be relevant in the evaluation of active labor market policies because such policies can be interpreted as measures that usually involve extending PBD and providing subsidies that correspond to UI benefits. Often, these active labor market policies target the long-term unemployed. In the light of our results, questions should be raised as to what extent current policies for long-term unemployed individuals are desirable. Our results indicate that interventions should not be measures of last resort but rather target unemployed individuals early during their unemployment spells. In general, investments in early retraining and well-targeted startup subsidies for unemployed individuals who have sustainable business 
ideas could increase the share of founders with a high potential for success (much like better financial development can improve the match between motivation and occupation, as suggested by Bianchi (2012)). Thus, fiscal externalities could be reduced, and social welfare improved.

\section{Conclusion}

This paper addresses the question of how potential unemployment insurance (UI) benefit duration (PBD) affects the actual unemployment duration before unemployed individuals become self-employed as well as their motivations for becoming self-employed and their outcomes as entrepreneurs. While existing literature has addressed how UI policies affect the unemployment duration and re-employment wages of those individuals transitioning to dependent employment, we are the first to address this issue in the context of transitions to self-employment by creating a new comprehensive dataset on founders in Germany. Since active labor market policies, which incentivize mainly long-term unemployed individuals to become self-employed, are commonly used as policy measures to fight unemployment, understanding the effects of the design of UI policies on startup success seems to be highly relevant.

Using the instrumental variables methods (RDD and DiD for robustness), we identify the causal effects of the policy variable, PBD, on entrepreneurial outcomes by exploiting reformand age-based exogenous variation in PBD within the German UI system. We find that in a sample of previously unemployed founders, longer PBD leads to longer actual unemployment duration and, through the latter, to increases in the propensity of unemployed individuals to feel pushed into self-employment (out of necessity) as opposed to starting a firm due to a business opportunity. Moreover, a longer unemployment duration is associated with a poorer entrepreneurial performance in terms of both employment growth and sales.

This negative overall causal relationship can be rationalized by a mix of both an effect on the composition of startups out of unemployment and an individual-level duration effect on the founders over the UI spell. In a stylized formal model, we demonstrate how both mechanisms explain why a government's policy change in PBD can generate our observed findings. Exploring the contributions of both mechanisms empirically, extensions of our analyses show little changes in the composition of the group of unemployed founders over different UI policy regimes. Our analyses therefore suggest that our results are driven by UI duration policy's effect on the individual-level entrepreneurial potential. 
A consistent explanation for this finding is that individuals' financial, social, and human capital depreciates in unemployment. An exact empirical derivation of the quantitative importance of the different mechanisms behind our findings, however, is beyond the scope of this paper. As in the literature focusing on the effect of UI on transitions to dependent employment (e.g. Schmieder and von Wachter, 2016), additional data and methods are needed to better assess the contributions of different mechanisms to the overall policy effect.

Given the current lack of evidence regarding the role of PBD on startup success and on self-employment in general, our results are of strong relevance from a public policy perspective. They show that it is important to consider self-employment as a post-unemployment outcome in typical optimal UI models, which are usually based on the sufficient statistics approach following the Baily-Chetty model (Chetty, 2009; Landais et al., 2018). Ignoring entrepreneurship out of unemployment likely leads to underestimating fiscal externalities. For instance, a UI policy could trigger firm creation by low-performing necessity entrepreneurs whose tax revenues will be comparably low or who may produce extra costs for society by returning to unemployment. Rather than pushing the long-term unemployed into self-employment, UI policies might therefore be better targeted at early re-training for those who might otherwise become self-employed out of necessity later. Our results are particularly relevant for all countries with generous UI benefit durations and countries granting extended UI benefits to founders starting a business out of unemployment. Due to its relatively low unemployment and self-employment rate levels, our results for Germany may be considered lower bound estimates for other countries. ${ }^{29}$

\footnotetext{
${ }^{29}$ E.g. Camarero Garcia and Hansch (2020) investigate the role of UI benefit levels on self-employment in Spain. They complement the present study by showing that the effects of PBD and UI benefits together constitute the total effect of UI on the transition channel from unemployment to self-employment.
} 


\section{References}

Aghion, P., Blundell, R., Griffith, R., Howitt, P. and Prantl, S. (2009), 'The Effects of Entry on Incumbent Innovation and Productivity', The Review of Economics and Statistics 91(1), 20-32.

Andersson, P. and Wadensjö, E. (2007), 'Do the Unemployed become Successful Entrepreneurs?', International Journal of Manpower 28(7), 604-626.

Berglann, H., Moen, E. R., Røed, K. and Skogstrøm, J. F. (2011), 'Entrepreneurship: Origins and Returns', Labour Economics 18(2), 180-193.

Bersch, J., Gottschalk, S., Mueller, B. and Niefert, M. (2014), 'The Mannheim Enterprise Panel (MUP) and Firm Statistics for Germany', ZEW Discussion Paper No. 14-104 .

Bianchi, M. (2012), 'Financial Development, Entrepreneurship, and Job Satisfaction', The Review of Economics and Statistics 94(1), 273-286.

Blanchflower, D. G. and Meyer, B. D. (1994), 'A Longitudinal Analysis of the Young SelfEmployed in Australia and the United States’, Small Business Economics 6(1), 1-19.

Burdett, K., Carrillo-Tudela, C. and Coles, M. (2020), 'The Cost of Job Loss', The Review of Economic Studies .

Cagetti, M. and De Nardi, M. (2006), 'Entrepreneurship, Frictions, and Wealth', Journal of Political Economy 114(5), 835-870.

Caliendo, M. and Kritikos, A. S. (2010), 'Start-ups by the Unemployed: Characteristics, Survival and Direct Employment Effects', Small Business Economics 35(1), 71-92.

Caliendo, M. and Künn, S. (2011), 'Start-up Subsidies for the Unemployed: Long-term Evidence and Effect Heterogeneity', Journal of Public Economics 95(3-4), 311-331.

Caliendo, M., Künn, S. and Weissenberger, M. (2019), 'Catching up or Lagging Behind ? The Long-Term Business and Innovation Potential of Subsidized Start-Ups out of Unemployment', IZA Discussion Paper (No. 12690) pp. 1-37.

Camarero Garcia, S. and Hansch, M. (2020), 'Unemployment Benefits and the Transition into Self-Employment', University of Mannheim Working Paper .

Card, D., Chetty, R. and Weber, A. (2007), 'The Spike at Benefit Exhaustion: Leaving the Unemployment System or Starting a New Job?', American Economic Review 97(2), 113-118.

Chetty, R. (2009), 'Sufficient Statistics for Welfare Analysis: A Bridge Between Structural and Reduced-Form Methods', Annual Review of Economics 1(1), 451-488.

Coad, A., Nielsen, K. and Timmermans, B. (2017), 'My first employee: an empirical investigation', Small Business Economics 48(1), 25-45.

Cottier, L., Degen, K. and Lalive, R. (2019), 'Can Unemployment Benefit Cuts Improve Employment and Earnings?’, Empirical Economics pp. 1-41.

Czarnitzki, D., Doherr, T., Hussinger, K., Schliessler, P. and Toole, A. A. (2015), 'Individual Versus Institutional Ownership of University-Discovered Inventions', ZEW Discussion Paper (No. 15-007) pp. 1-60. 
DellaVigna, S., Heining, J., Schmieder, J. F. and Trenkle, S. (2020), 'Evidence on Job Search Models from a Survey of Unemployed Workers in Germany', UC Berkeley Working Paper .

Dent, R. C., Karahan, F., Pugsley, B. and Şahin, A. (2016), 'The Role of Startups in Structural Transformation', American Economic Review 106(5), 219-223.

Doris, A., O'Neill, D. and Sweetman, O. (2018), 'Does Reducing Unemployment Benefits During a Recession Reduce Youth Unemployment? Evidence from a 50 Percent Cut in Unemployment Assistance', Journal of Human Resources pp. 1-65.

Dustmann, C., Ludsteck, J. and Schönberg, U. (2009), 'Revisiting the German Wage Structure', Quarterly Journal of Economics 124(2), 843-881.

Evans, D. S. and Leighton, L. S. (1990a), 'Small Business Formation by Unemployed and Employed Workers', Small Business Economics 2(4), 319-330.

Evans, D. S. and Leighton, L. S. (1990b), 'Some Empirical Aspects of Entrepreneurship', American Economic Review 79(3), 79-99.

Farber, H. S., Rothstein, J. and Valletta, R. G. (2015), 'The Effect of Extended Unemployment Insurance Benefits: Evidence from the 2012-2013 Phase-Out', American Economic Review 105(5), 171-176.

Fryges, H., Gottschalk, S. and Kohn, K. (2010), 'The KfW / ZEW Start-up Panel: Design and Research Potential', Schmollers Jahrbuch 130(1), 117-131.

Haltiwanger, J., Jarmin, R. S. and Miranda, J. (2013), 'Who Creates Jobs? Small versus Large versus Young', The Review of Economics and Statistics 95(2), 347-361.

Hartung, B., Jung, P. and Kuhn, M. (2018), 'What Hides Behind the German Labor Market Miracle? Unemployment Insurance Reforms and Labor Market Dynamics', IZA Discussion Papers (No. 12001) pp. 1-66.

Hombert, J., Schoar, A., Sraer, D. and Thesmar, D. (2020), 'Can Unemployment Insurance Spur Entrepreneurial Activity? Evidence from France', The Journal of Finance .

Hopenhayn, H. A. and Nicolini, J. P. (1997), 'Optimal Unemployment Insurance', Journal of Political Economy 105(2), 412-438.

Imbens, G. W. and Lemieux, T. (2008), 'Regression discontinuity designs: A guide to practice', Journal of Econometrics 142(2), 615-635.

Jäger, S., Schoefer, B., Young, S. and Zweimüller, J. (2019), 'Wages and the Value of Nonemployment', MIT Working Paper pp. 1-115.

Jarosch, G. and Pilossoph, L. (2019), 'Statistical Discrimination and Duration Dependence in the Job Finding Rate', The Review of Economic Studies 86(4), 1631-1665.

Katz, L. F. and Meyer, B. D. (1990a), 'The Impact of the Potential Duration of Unemployment Benefits on the Duration of Unemployment', Journal of Public Economics 41(1), 45-72.

Katz, L. F. and Meyer, B. D. (1990b), 'Unemployment Insurance, Recall Expectations, and Unemployment Outcomes’, Quarterly Journal of Economics 105(4), 973-1002. 
Kolsrud, J., Landais, C., Nilsson, P. and Spinnewijn, J. (2018), 'The Optimal Timing of Unemployment Benefits: Theory and Evidence from Sweden', American Economic Review 108(4-5), 985-1033.

Kroft, K. and Notowidigdo, M. J. (2016), 'Should Unemployment Insurance Vary with the Unemployment Rate? Theory and Evidence', The Review of Economic Studies 83(3), 10921124.

Kuhn, P. J. and Schuetze, H. J. (2001), 'Self-employment Dynamics and Self-employment Trends: A Study of Canadian Men and Women, 1982-1998', Canadian Journal of Economics 34(3), 760-784.

Lalive, R. (2008), 'How do Extended Benefits Affect Unemployment Duration? A Regression Discontinuity Approach', Journal of Econometrics 142(2), 785-806.

Lalive, R., Van Ours, J. and Zweimüller, J. (2006), 'How Changes in Financial Incentives Affect the Duration of Unemployment', The Review of Economic Studies 73(4), 1009-1038.

Landais, C., Michaillat, P. and Saez, E. (2018), 'A Macroeconomic Approach to Optimal Unemployment Insurance: Theory’, American Economic Journal: Economic Policy 10(2), 152181.

Lawson, N. (2017), 'Fiscal Externalities and Optimal Unemployment Insurance', American Economic Journal: Economic Policy 9(4), 281-312.

Le Barbanchon, T. (2016), 'The Effect of the Potential Duration of Unemployment Benefits on Unemployment Exits to Work and Match Quality in France', Labour Economics 42, 16-29.

Le Barbanchon, T., Rathelot, R. and Roulet, A. (2019), 'Unemployment Insurance and Reservation Wages: Evidence from Administrative Data', Journal of Public Economics 171, 1-17.

Lee, D. S. and Lemieux, T. (2010), 'Regression Discontinuity Designs in Economics', Journal of Economic Literature 48(2), 281-355.

Levine, R. and Rubinstein, Y. (2017), 'Smart and Illicit: Who Becomes an Entrepreneur and Do They Earn More?', Quarterly Journal of Economics 132(2), 963-1018.

Lichter, A. (2016), 'Benefit Duration and Job Search Effort: Evidence from a Natural Experiment', IZA Discussion Paper (No. 10264) pp. 1-38.

McCrary, J. (2008), 'Manipulation of the running variable in the regression discontinuity design: A density test', Journal of Econometrics 142(2), 698-714.

Meager, N. (1992), 'Does Unemployment Lead to Self-Employment?', Small Business Economics 4(2), 87-103.

Nekoei, A. and Weber, A. (2017), 'Does Extending Unemployment Benefits Improve Job Quality?', American Economic Review 107(2), 527-561.

Oberholzer-Gee, F. (2008), 'Nonemployment Stigma as Rational Herding: A Field Experiment', Journal of Economic Behavior and Organization 65(1), 30-40. 
Petrunyk, I. and Pfeifer, C. (2018), 'Shortening the Potential Duration of Unemployment Benefits and Labor Market Outcomes: Evidence from a Natural Experiment in Germany', IZA Discussion Paper (No. 11300) pp. 1-48.

Price, B. (2019), 'The Duration and Wage Effects of Long-Term Unemployment Benefits: Evidence from Germany's Hartz IV Reform', UC Davis Working Paper Series, pp. 1-67.

Røed, K. and Skogstrøm, J. F. (2014a), 'Job Loss and Entrepreneurship', Oxford Bulletin of Economics and Statistics 76(5), 727-744.

Røed, K. and Skogstrøm, J. F. (2014b), 'Unemployment Insurance and Entrepreneurship', Labour 28(4), 430-448.

Schmieder, J. F. and von Wachter, T. (2016), 'The Effects of Unemployment Insurance Benefits: New Evidence and Interpretation', Annual Review of Economics 8(1), 547-581.

Schmieder, J. F., von Wachter, T. and Bender, S. (2012), 'The Effects of Extended Unemployment Insurance Over the Business Cycle: Evidence from Regression Discontinuity Estimates Over 20 Years', Quarterly Journal of Economics 127(2), 701-752.

Schmieder, J. F., von Wachter, T. and Bender, S. (2016), 'The Effect of Unemployment Benefits and Nonemployment Durations on Wages', American Economic Review 106(3), 739-777.

Sedláček, P. and Sterk, V. (2017), 'The Growth Potential of Startups over the Business Cycle', American Economic Review 107(10), 3182-3210.

von Greiff, J. (2009), ‘Displacement and Self-employment Entry', Labour Economics 16(5), 556565.

von Wachter, T. and Bender, S. (2006), 'In the Right Place at the Wrong Time: The Role of Firms and Luck in Young Workers' Careers', American Economic Review 96(5), 1679-1705.

\section{List of Abbreviations}

AUD actual unemployment duration.

DiD Difference-in-Differences.

FTE full-time equivalent.

IAB Institute for Employment Research of the German Federal Employment Agency.

IV Instrumental Variable.

PBD potential benefit duration.

RDD Regression Discontinuity Design.

SE self-employed.

UI unemployment insurance.

ZEW Leibniz Centre for European Economic Research. 


\section{Figures \& Tables}

Figure 1: Firm Outcomes in Years after Foundation for All Founders

(a) Sales in EUR

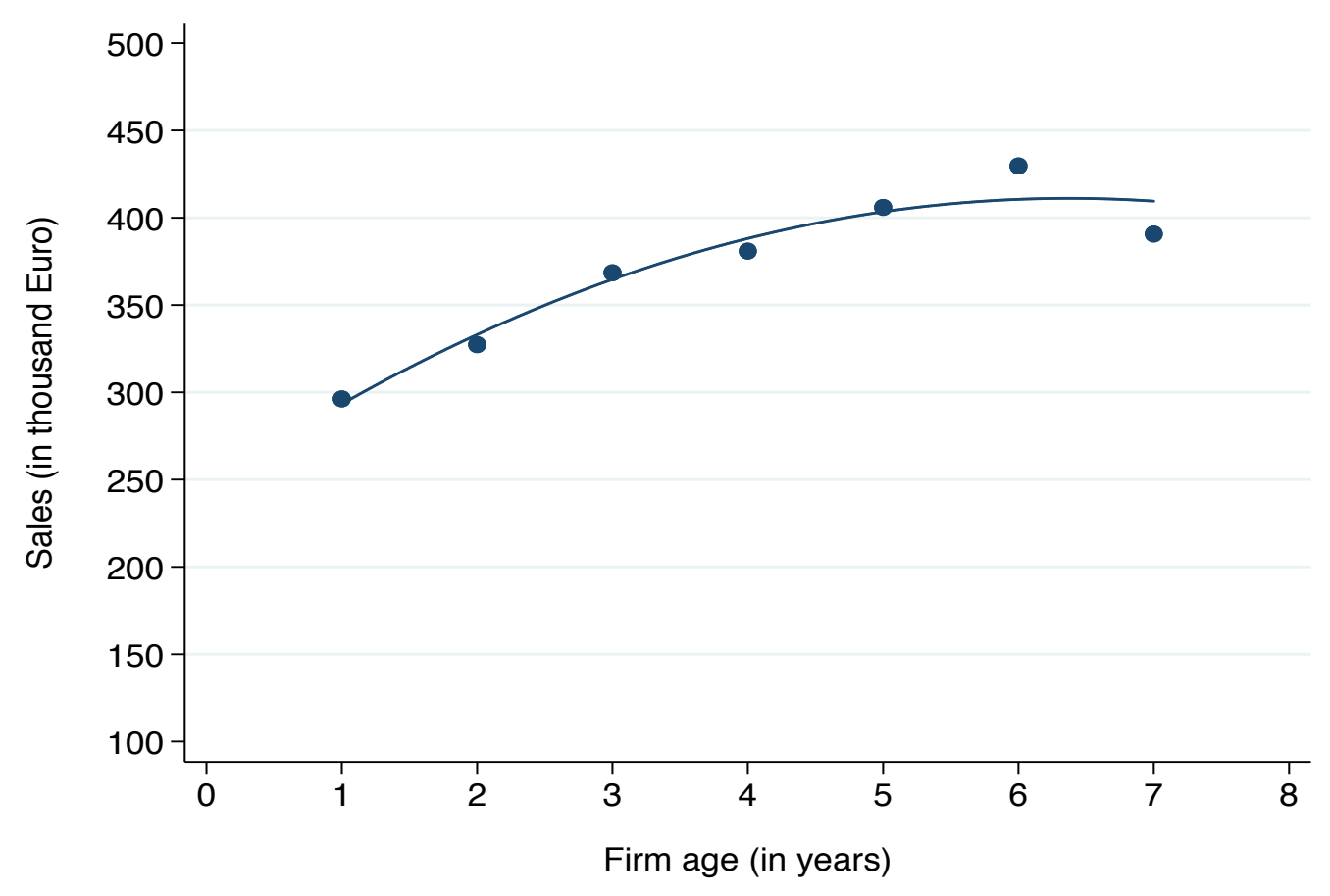

(b) Full-Time Equivalent Employment

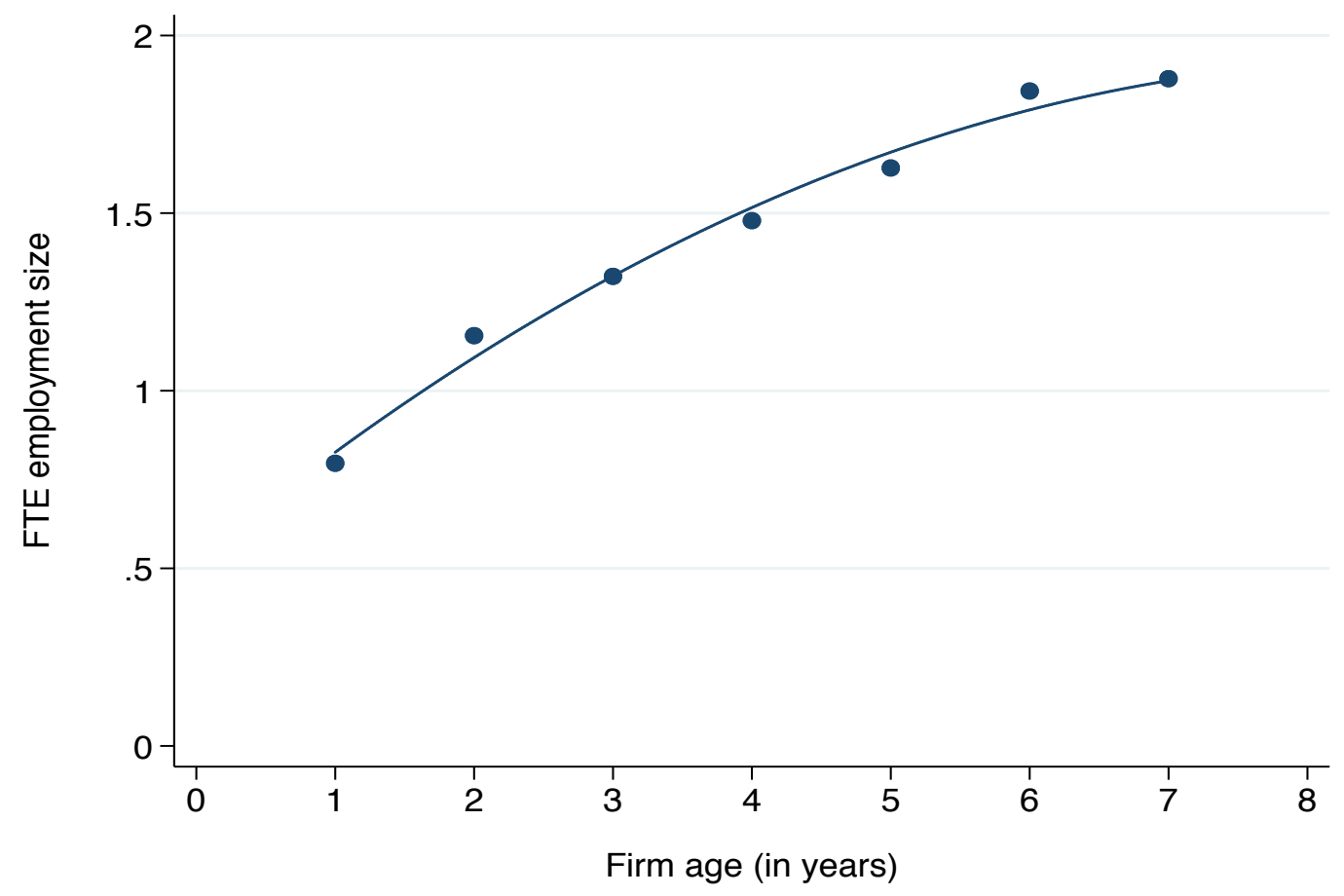

Notes: The Figure shows firm outcomes of non-team founders aged 35-65 (analogous to the definition of our main estimation sample) in years after foundation. We see the outcomes of startups in terms of sales per year and full-time equivalent employment based on 5,250 (sales) and 5,850 (employment) startups established between 2005 and 2011 from our linked dataset (see Section 2). Firms usually stay in the panel for seven years but can drop out if they fail or refuse to take part in more than two consecutive years. Thus, less firms are observed in year seven compared to year one after starting up. 
Figure 2: Firm Outcomes in Years after Foundation by Previous Employment Status

(a) Sales in EUR

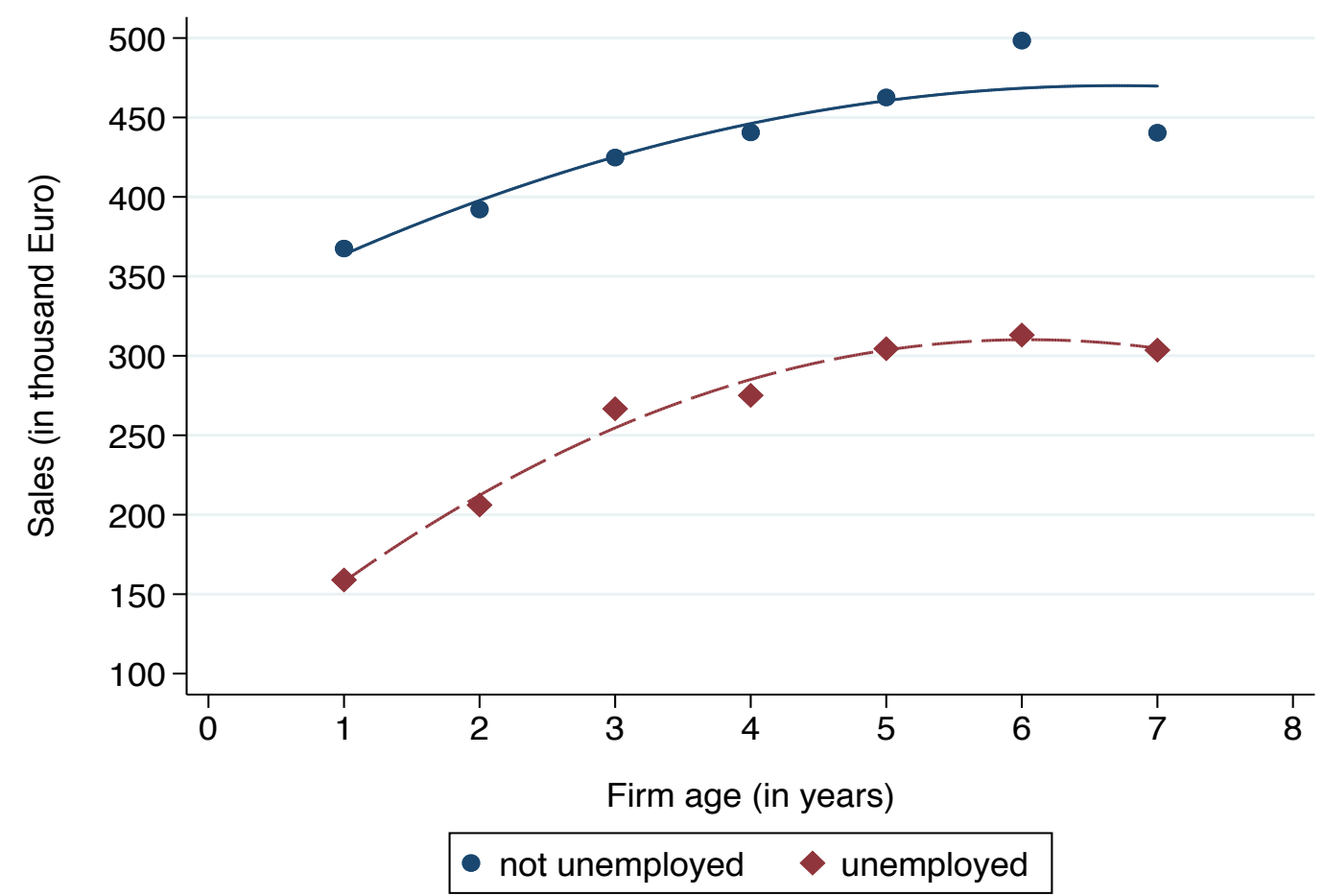

(b) Full-Time Equivalent Employment

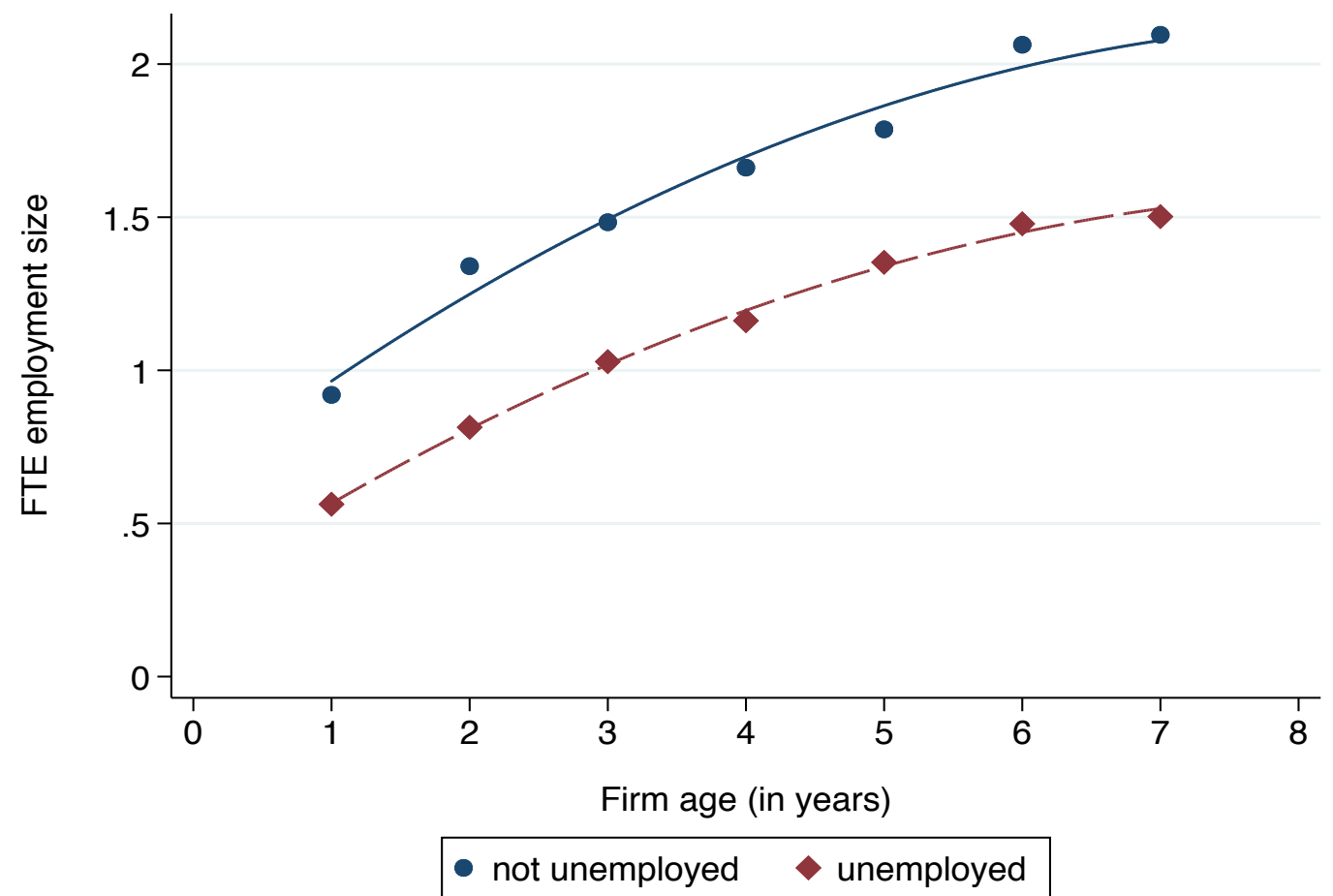

Notes: The Figure shows firm outcomes of non-team founders aged 35-65 (see the definition of our main estimation sample in Table 1) in years after foundation split by the previous labor market status of the founder (not unemployed or unemployed). We cover startups established between 2005 and 2011 from our linked dataset as described in Section 2. 
Figure 3: Firm Outcomes in Years after Foundation split by Median Unemployment Duration

(a) Sales in EUR

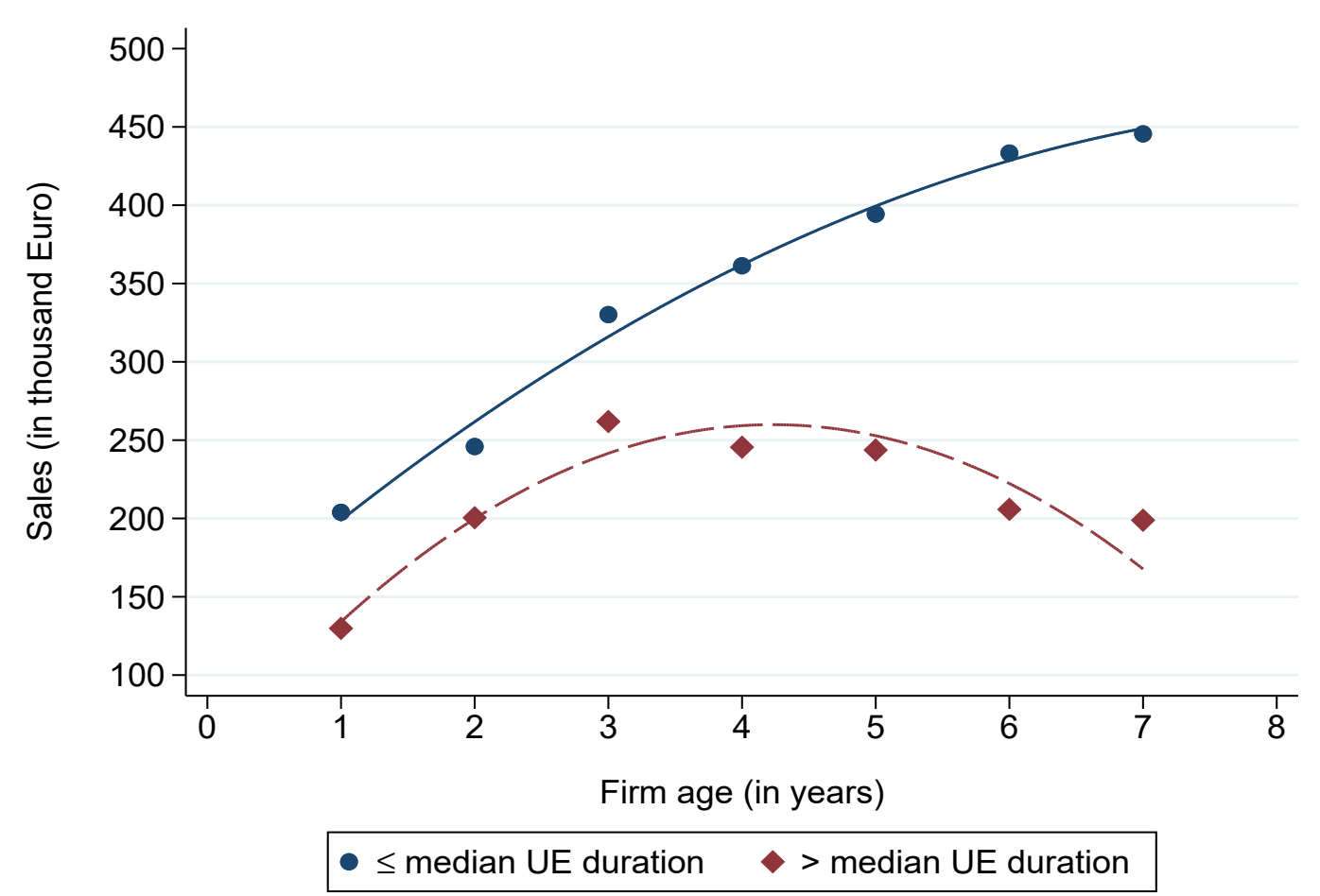

(b) Full-Time Equivalent Employment

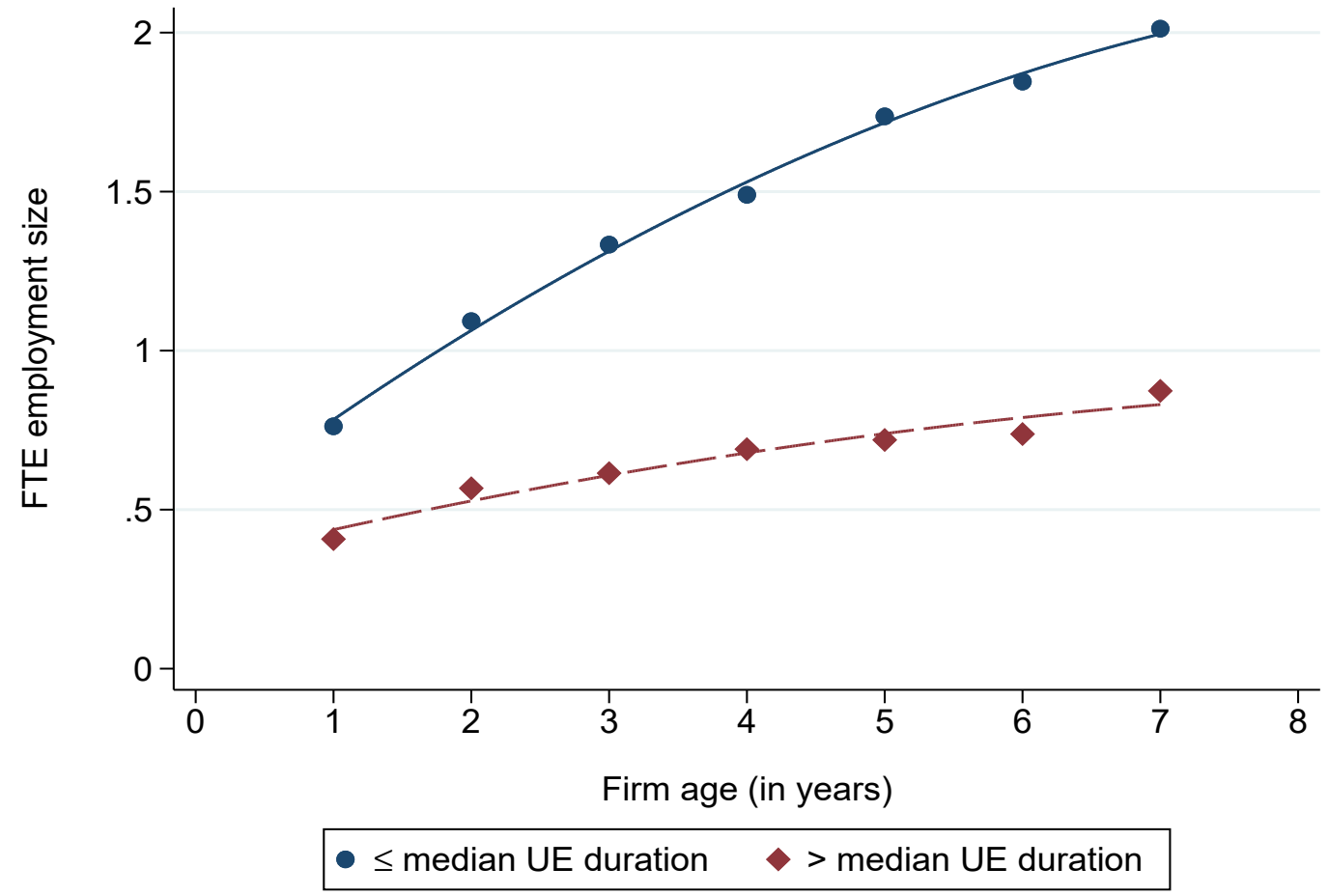

Notes: The Figure shows firm outcomes of non-team founders aged 35-65 (see the definition of our main estimation sample in Table 1) with previous unemployment spell in years after foundation split at the medium (actual) unemployment duration. We cover startups established between 2005 and 2011 from our linked dataset as described in Section 2. 
Figure 4: Firm Outcomes in Years after Foundation split by Motivation for Starting Up

(a) Sales in EUR

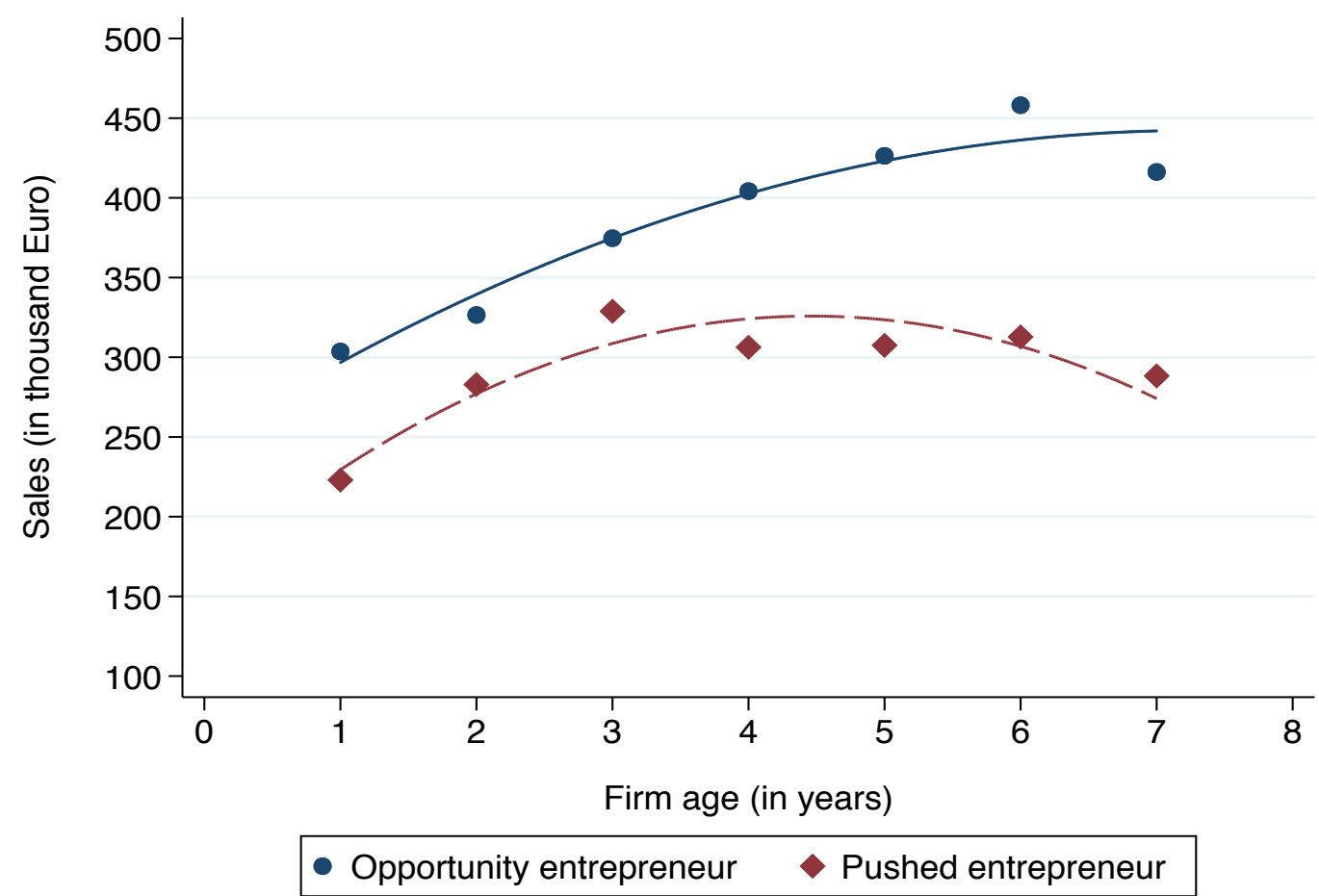

(b) Full-Time Equivalent Employment

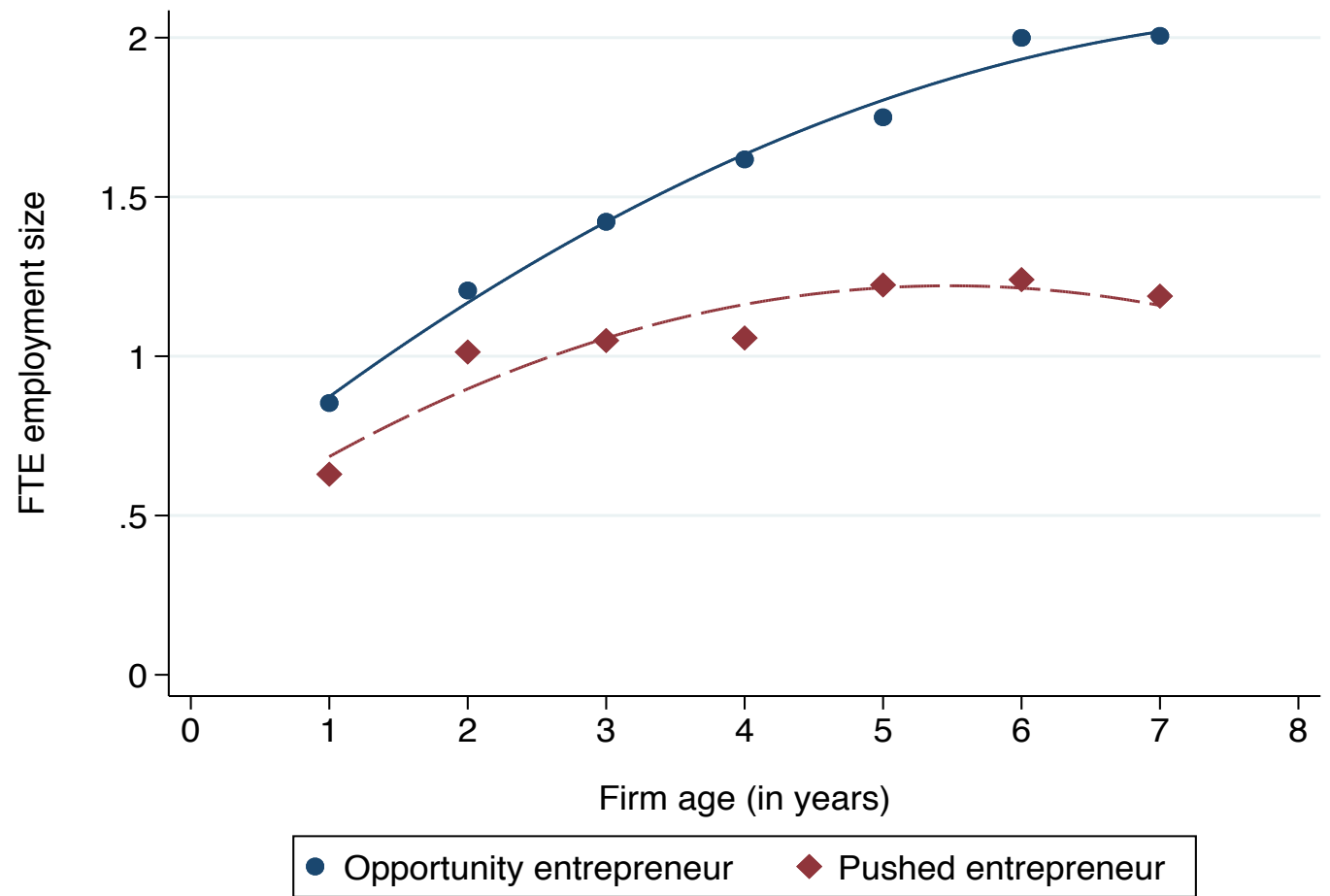

Notes: The Figure shows firm outcomes of non-team founders aged 35-65 (analogous to the definition of our main estimation sample) in years after foundation split by self-reported motivation, i.e. opportunity vs. pushed/necessity driven entrepreneurship. We cover approximately 5,050 (sales) and 5,600 (employment) startups established between 2005 and 2011 from our linked dataset as described in Section 2. The notion of using, instead of necessity-driven founder, the term pushed entrepreneur is best understood by checking the spikes of the exit rate from unemployment into self-employment split by the motivation to start up which is shown in Figure A.1. 
Figure 5: Firm Outcomes in Years after Foundation by Motivation for Starting Up out of Unemployment (a) Sales in EUR

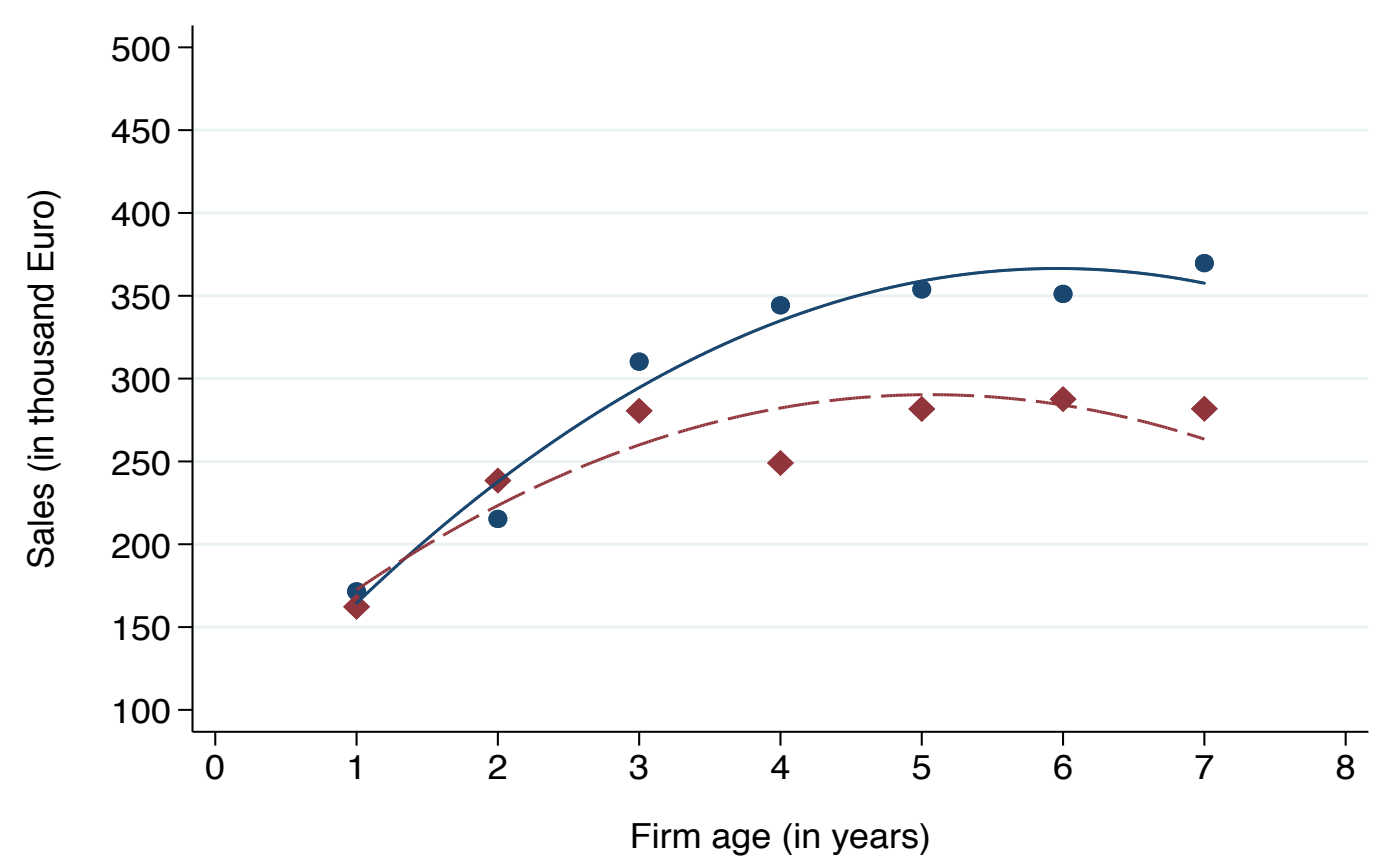

- UE opportunity entrepreneur

UE pushed entrepreneur

(b) Full-Time Equivalent Employment

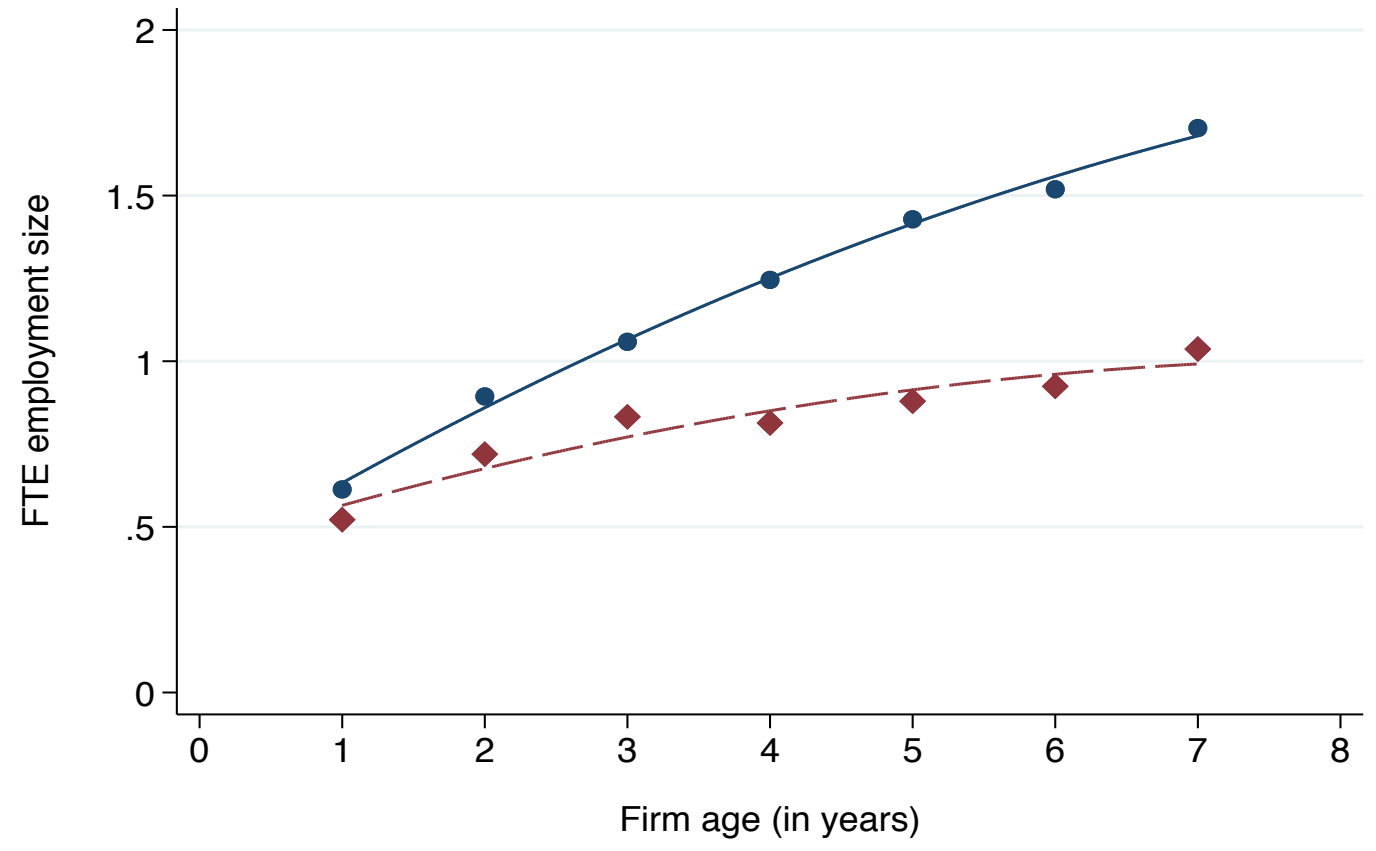

UE opportunity entrepreneur $\diamond$ UE pushed entrepreneur

Notes: The Figure shows firm outcomes of non-team founders aged 35-65 (see the definition of our main estimation sample in Table 1) with previous unemployment spell in years after foundation split by self-reported motivation, i.e. opportunity vs. pushed/necessity driven entrepreneurship. We cover startups established between 2005 and 2011 from our linked dataset as described in Section 2. 
Figure 6: Selection into Self-Employment

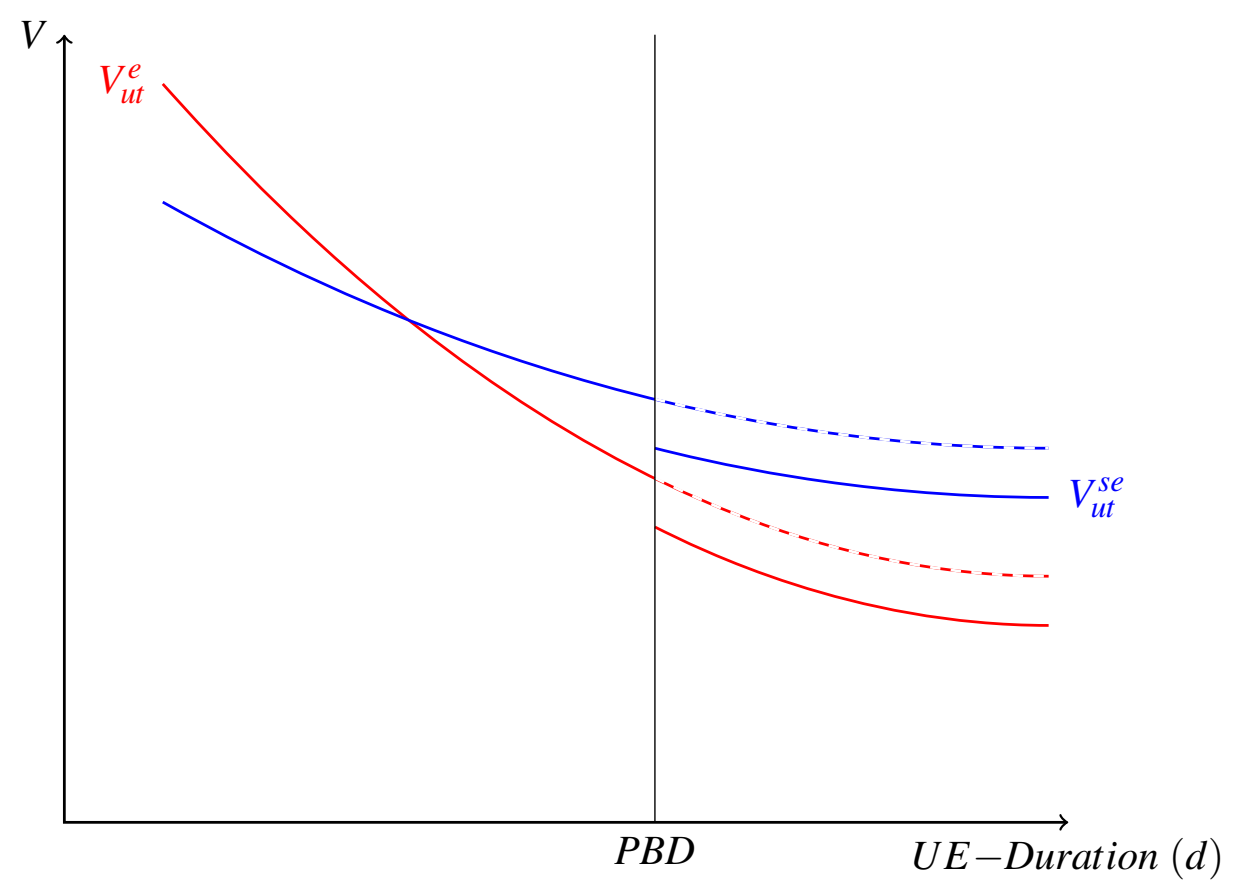

Notes: The figure illustrates how the value functions for becoming employed $V_{u t}^{e}$ and self-employed $V_{u t}^{s e}$ evolve with actual unemployment duration (AUD) $d$ according to the stylized model as explained in Section 5. The red line depicts $\frac{\partial V_{u t}^{e}}{\partial d} \mid \theta<0$. The blue line depicts $\frac{\partial V_{u t}^{s e}}{\partial d} \mid \theta$ for which it holds that: $0>\frac{\partial V_{u t}^{s e}}{\partial d}\left|\theta>\frac{\partial V_{u t}^{e}}{\partial d}\right| \theta$. The vertical black line marks the potential benefit duration (PBD). At this point of unemployment duration the red/blue line drop by $x=\bar{b}-\tilde{b}$ because UI benefits $\bar{b}$ drop to the existential minimum $\tilde{b}$ (compare Equation (8) and Equation (10)). In this example, the unemployed individual would first prefer to search for employment. But once the red line crosses the blue one: from this unemployment duration (d) onward, the unemployed individual would prefer starting a business. Note that these results hold as long as depreciation in entrepreneurial skills is smaller in absolute terms than depreciation in employment skills and thus as long as the blue line has a less negative slope than the red line. If the value of becoming self-employed out of unemployment was independent of unemployment duration $d$, the blue line would be a horizontal line, and the associated pure selection channel (composition effect) could also explain our main results, i.e. that longer PBD leads to longer actual unemployment duration and more pushed startups. 
Figure 7: Selection into Self-Employment: High Entrepreneurial Ability

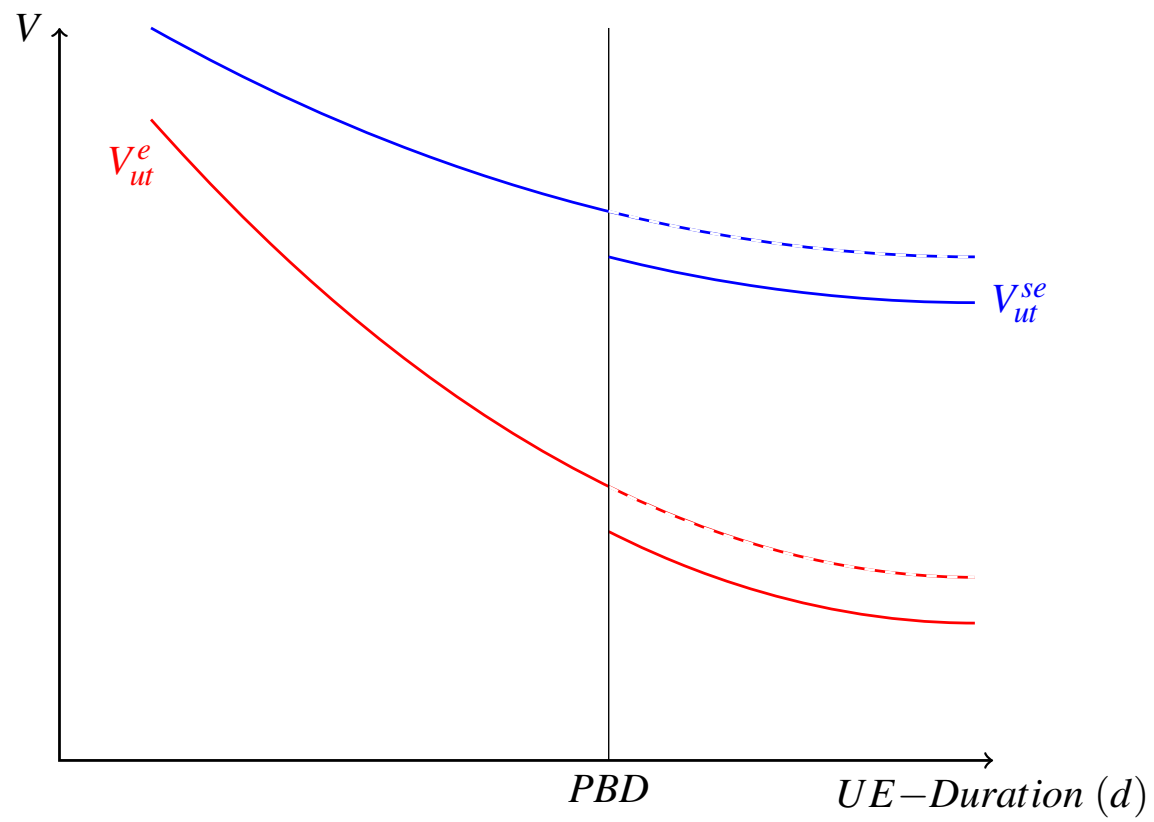

Notes: The figure illustrates how the value functions for becoming employed $V_{u t}^{e}$ and self-employed $V_{u t}^{s e}$ evolve with unemployment duration (AUD) $d$ according to the stylized model as explained in Section 5. The red line depicts $\frac{\partial V_{u t}^{e}}{\partial d} \mid \theta<0$. The blue line depicts $\frac{\partial V_{u t}^{s e}}{\partial d} \mid \theta$ for which it holds that: $0>\frac{\partial V_{u t}^{s e}}{\partial d}\left|\theta>\frac{\partial V_{u t}^{e}}{\partial d}\right| \theta$. The vertical black line marks the potential benefit duration: at this point of unemployment duration the red/blue line drops by $x=\bar{b}-\tilde{b}$, as UI benefits $\bar{b}$ drop to the existential minimum $\tilde{b}$ (Equation (8) and Equation (10)). The unemployed individual learns to have such high (entrepreneurial) ability that she starts a business.

Figure 8: Selection into Employment: Low Entrepreneurial Ability

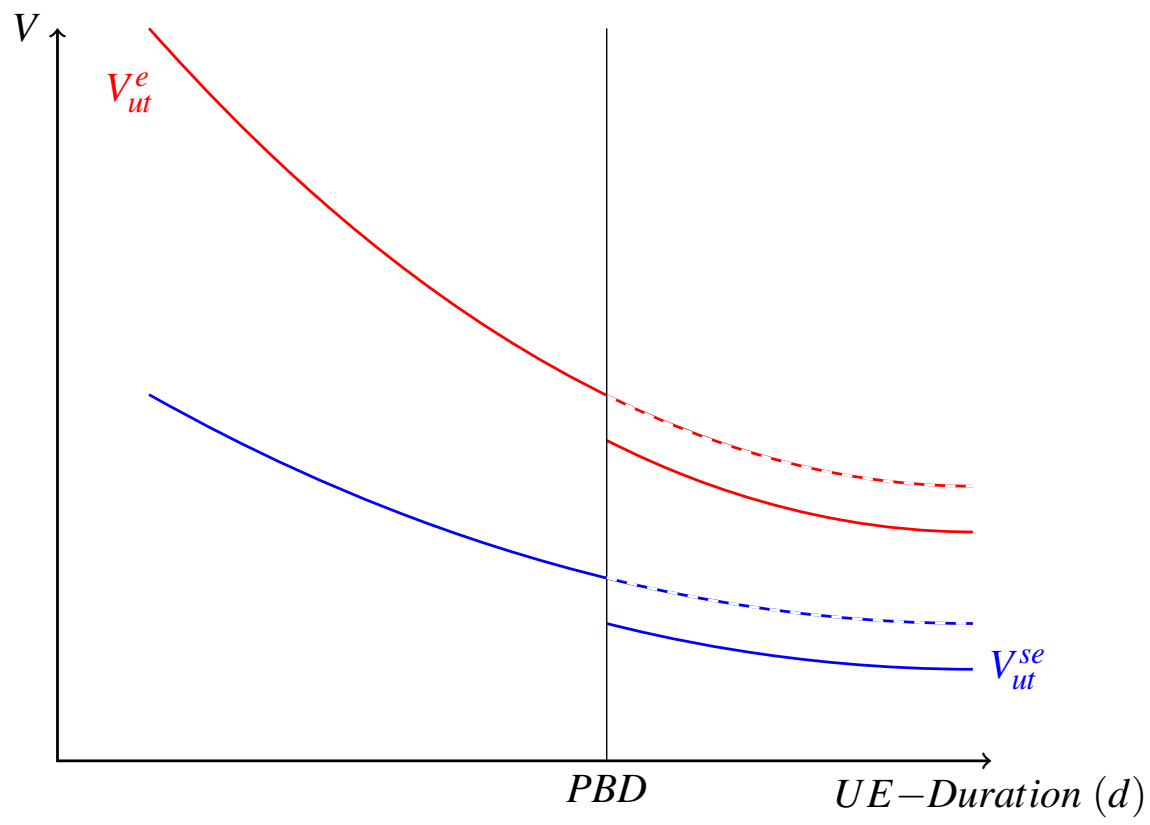

Notes: The figure illustrates how the value functions for becoming employed $V_{u t}^{e}$ and self-employed $V_{u t}^{s e}$ evolve with unemployment duration (AUD) $d$ according to the stylized model as explained in Section 5. The red line depicts $\frac{\partial V_{u t}^{e}}{\partial d} \mid \theta<0$. The blue line depicts $\frac{\partial V_{u t}^{s e}}{\partial d} \mid \theta$ for which it holds that: $0>\frac{\partial V_{u t}^{s e}}{\partial d}\left|\theta>\frac{\partial V_{u t}^{e}}{\partial d}\right| \theta$. The vertical black line marks the potential benefit duration: at this point of unemployment duration the red/blue line drops by $x=\bar{b}-\tilde{b}$, as UI benefits $\bar{b}$ drop to the existential minimum $\tilde{b}$ (Equation (8) and Equation (10)). The unemployed individual learns to have such low (entrepreneurial) ability that she prefers employment. 
Figure 9: PBD Rules can influence the Composition of Startups out of Unemployment

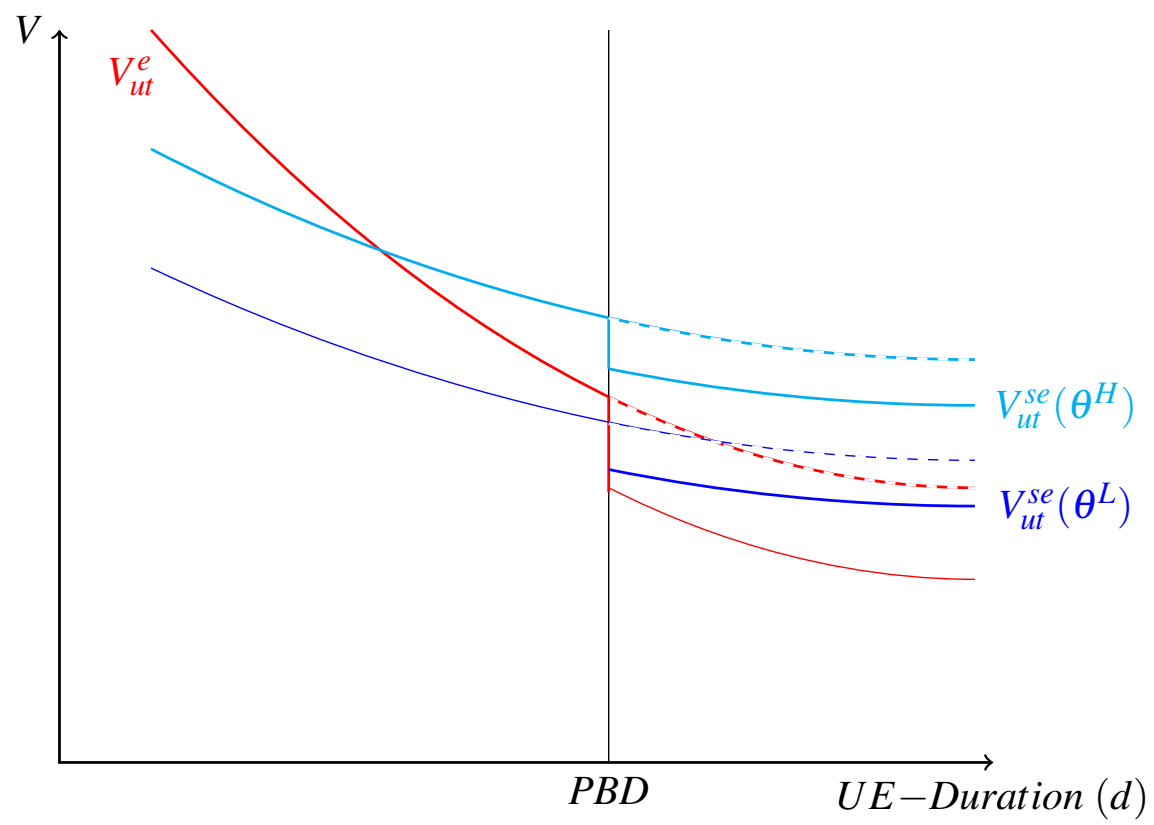

Notes: The figure illustrates how the value functions for becoming employed $V_{u t}^{e}$ and self-employed $V_{u t}^{s e}$ evolve with unemployment duration (AUD) $d$ according to the stylized model in Section 5. The red line depicts $\frac{\partial V_{u t}^{e}}{\partial d} \mid \theta<0$. The cyan/blue line depicts $\frac{\partial V_{u t}^{s e}}{\partial d} \mid \theta$ for which it holds that: $0>\frac{\partial V_{u t}^{s e}}{\partial d}\left|\theta>\frac{\partial V_{u t}^{e}}{\partial d}\right| \theta$. The vertical black line marks the potential benefit duration (PBD): at this point of unemployment duration the red/blue line drops by $x=\bar{b}-\tilde{b}$, as UI benefits $\bar{b}$ drop to the existential minimum $\tilde{b}$ (Equation (8) and Equation (10)). In this example, the unemployed individual with high ability $\theta_{H}$ would decide to become self-employed after a short UI duration (cyan line), whereas the other unemployed individual $\theta_{L}$ would intensify search for employment before reaching PBD (red line to the left of PBD), when $V_{u t}^{e}$ suddenly drops below $V_{u t}^{s e}$ (blue line to the right of PBD). Here, the government could induce type $H$ to become self-employed and $L$ to search for employment.

Figure 10: If there was No Negative UI Duration Dependence concerning potential SE Outcomes

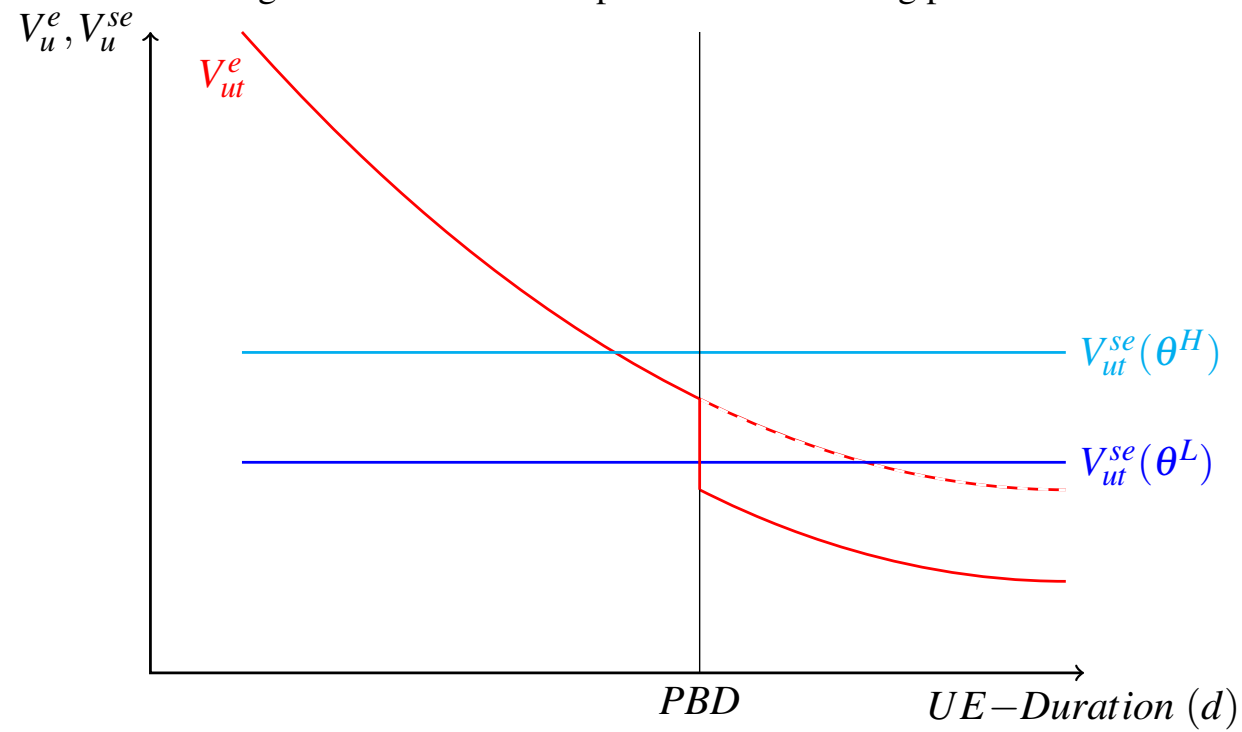

Notes: The figure illustrates how the value functions for becoming employed $V_{u t}^{e}$ and self-employed $V_{u t}^{s e}$ evolve with unemployment duration $d$ according to the stylized model as explained in Section 5. The red line depicts $\frac{\partial V_{u t}^{e}}{\partial d} \mid \theta<0$. The blue line depicts $\frac{\partial V_{u t}^{s e}}{\partial d} \mid \theta=0$. The vertical black line marks PBD: at this point of unemployment duration the red/blue line drops by $x=\bar{b}-\tilde{b}$, as UI benefits $\bar{b}$ drop to the existential minimum $\tilde{b}$ ( Equation (8) and Equation (10)). 
Figure 11: PBD Rules can influence the Composition of Startups out of Unemployment (Increase in PBD)

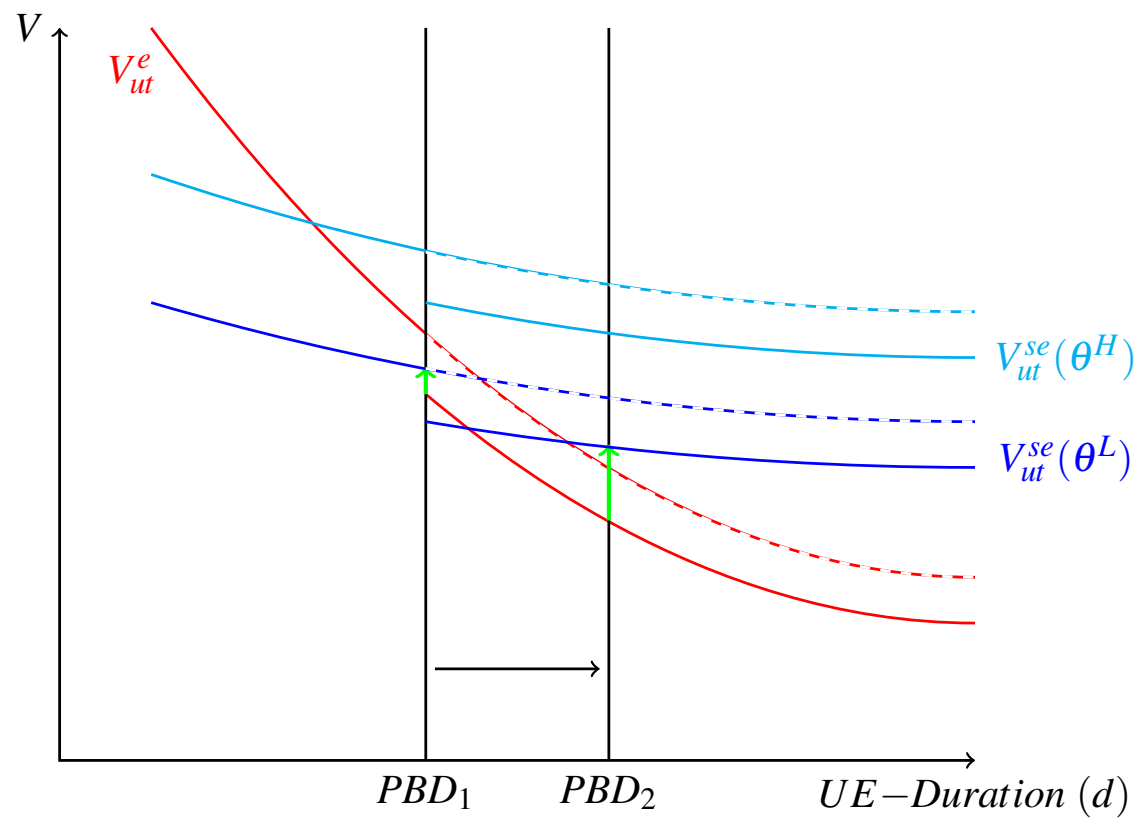

Notes: The figure illustrates how the value functions for becoming employed $V_{u t}^{e}$ and self-employed $V_{u t}^{s e}$ evolve with unemployment duration (AUD) $d$ according to the stylized model in Section 5. The red line depicts $\frac{\partial V_{u t}^{e}}{\partial d} \mid \theta<0$. The cyan/blue line depicts $\frac{\partial V_{u t}^{s e}}{\partial d} \mid \theta$ for which it holds that: $0>\frac{\partial V_{u t}^{s e}}{\partial d}\left|\theta>\frac{\partial V_{u t}^{e}}{\partial d}\right| \theta$. The vertical black line marks the potential benefit duration (PBD): at this point of unemployment duration the red/blue line drops by $x=\bar{b}-\tilde{b}$, as UI benefits $\bar{b}$ drop to the existential minimum $\tilde{b}$ (Equation (8) and Equation (10)). In this example, the government increases PBD ( $P B D$ moves to the right). $P B D_{1}$ represents the initial potential benefit duration. $P B D_{2}$ the extended one. At the initial $P B D_{1}$, the unemployed individual with high ability $\left(\theta_{H}\right)$ would decide to become self-employed after a short UI duration (cyan line), whereas the other unemployed individual $\left(\theta_{L}\right)$ would rather accept the next job when reaching $P B D_{1}$ (red curve is above dark blue curve at $P B D_{1}$ ). This illustrates, that in theory, increasing the potential benefit duration to $P B D_{2}$ can change the composition among the unemployed individuals start up. Now, the value for becoming self-employed would be higher for both high individuals with $\theta_{H}$ (opportunity entrepreneurs) and for individuals with $\theta_{L}$ (necessity entrepreneurs) compared to the value for transitioning from unemployment to wage employment (at $P B D_{2}$ the dark blue curve is now above the red curve). This illustrates how PBD can change the composition of startups created out of unemployment. 
Figure 12: Early Re-training for Wage-Employment

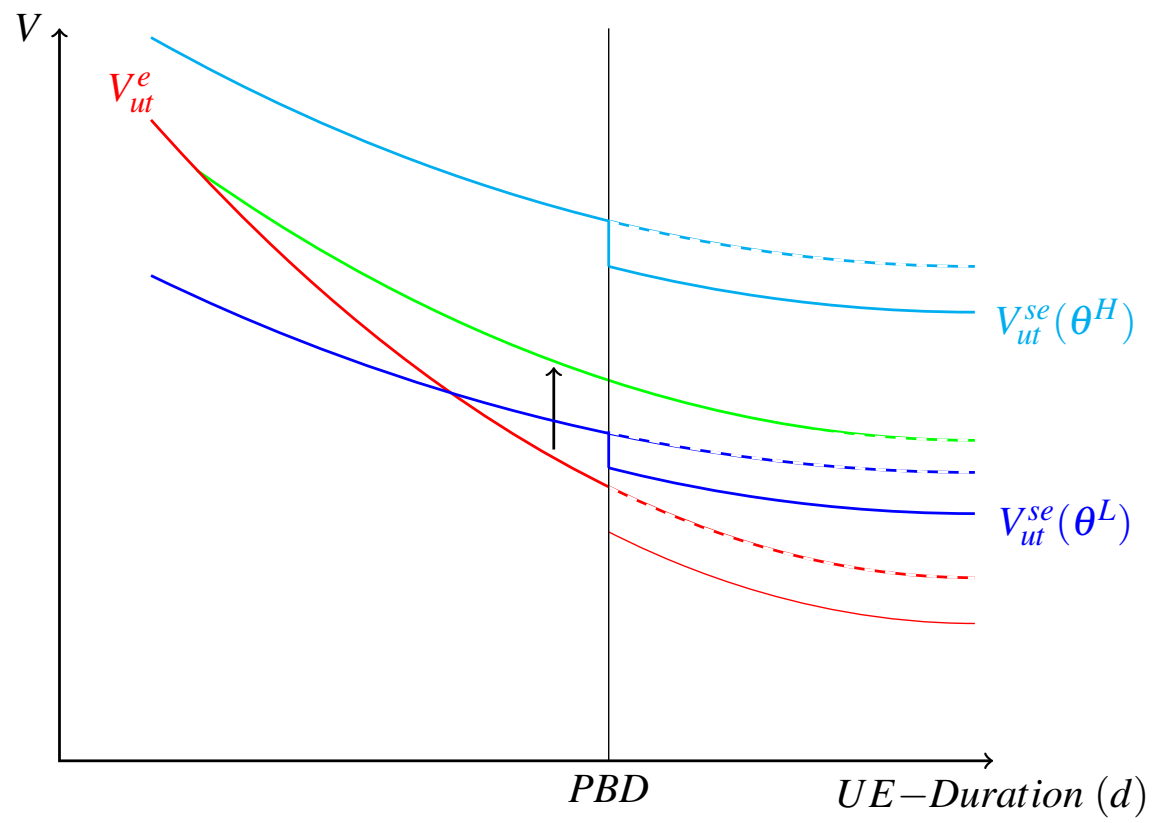

Notes: The figure illustrates how the value functions for becoming employed $V_{u t}^{e}$ and self-employed $V_{u t}^{s e}$ evolve with unemployment duration $d$ according to the stylized model in Section 5. The red line depicts $\frac{\partial V_{u t}^{e}}{\partial d} \mid \theta<0$. The cyan/blue line depicts $\frac{\partial V_{u t}^{s e}}{\partial d} \mid \theta$ for which it holds that: $0>\frac{\partial V_{u t}^{s e}}{\partial d}\left|\theta>\frac{\partial V_{u t}^{e}}{\partial d}\right| \theta$. The vertical black line marks the potential benefit duration (PBD): at this point of $d$ the red/blue line drops by $x=\bar{b}-\tilde{b}$, as UI benefits $\bar{b}$ drop to the existential minimum $\tilde{b}$ (Equation (8), Equation (10)). By early retraining, the value function of searching for employment $V_{u t}^{e}$ could be increased, as the green line indicates.

Figure 13: Targeted Subsidies for Self-Employment

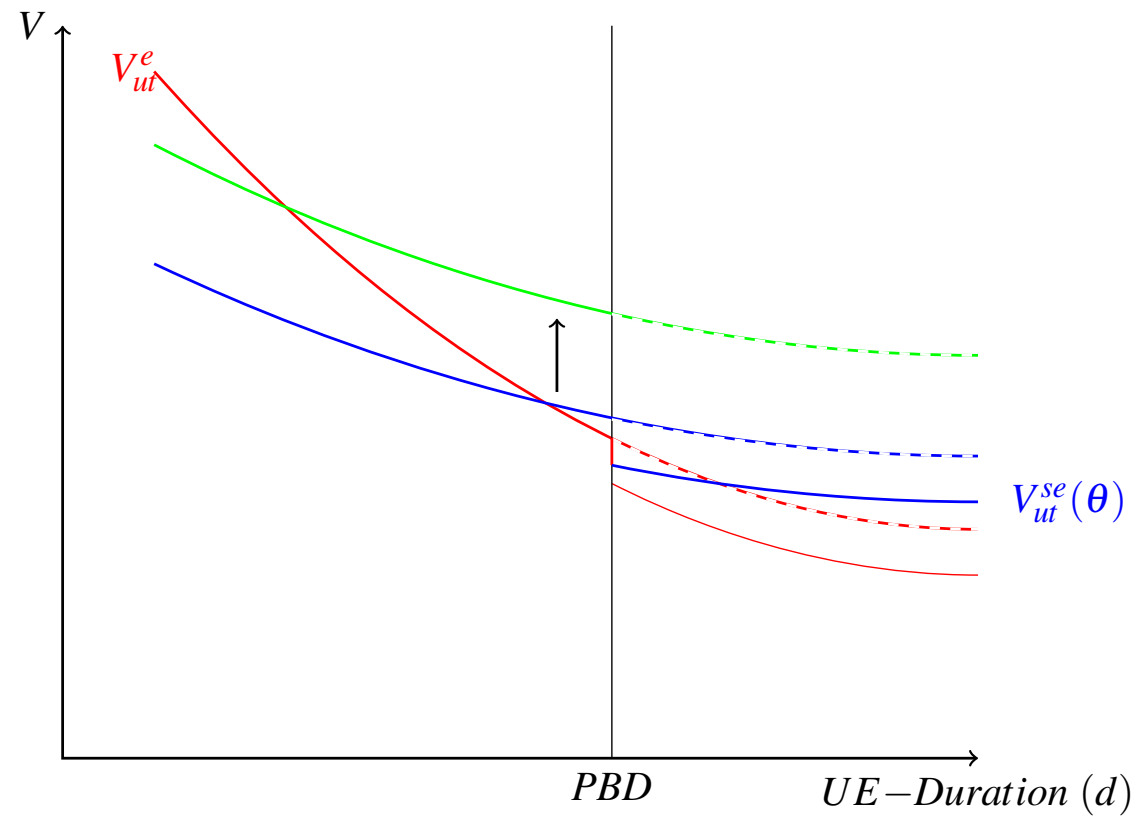

Notes: The figure shows how the value functions for becoming employed $V_{u t}^{e}$ and self-employed $V_{u t}^{s e}$ evolve with unemployment duration $d$ according to the stylized model in Section 5. The red line depicts $\frac{\partial V_{u t}^{e}}{\partial d} \mid \theta<0$. The blue line depicts $\frac{\partial V_{u t}^{s e}}{\partial d} \mid \theta$ for which it holds that: $0>\frac{\partial V_{u t}^{s e}}{\partial d}\left|\theta>\frac{\partial V_{u t}^{e}}{\partial d}\right| \theta$. The vertical black line marks the potential benefit duration (PBD): at this point of unemployment duration the red/blue line drops by $x=\bar{b}-\tilde{b}$, as UI benefits $\bar{b}$ drop to the existential minimum $\tilde{b}$ (Equation (8) and Equation (10)). By providing startup subsidies or special training for future self-employed, the government could increase $V_{u t}^{s e}$, as shown by the green line. 


\subsection{Tables}

Table 1: Summary Statistics: Regression Sample - for previously Unemployed (above median unemployment duration) or Employed Founders

\begin{tabular}{|c|c|c|c|c|c|c|c|c|c|c|c|c|c|c|c|}
\hline \multirow[b]{2}{*}{ Variable } & \multicolumn{5}{|c|}{ Regression sample of unemployed founders } & \multicolumn{5}{|c|}{ Founders with $>$ median AUD } & \multicolumn{5}{|c|}{ Previously not unemployed founders } \\
\hline & $\mathrm{N}$ & Mean & SD & Min & Max & $\mathrm{N}$ & Mean & SD & Min & Max & $\mathrm{N}$ & Mean & SD & Min & Max \\
\hline $\begin{array}{l}\text { Actual unemployment duration (AUD) (in months) } \\
\text { Potential benefit duration (PBD) (in months) }\end{array}$ & $\begin{array}{l}1291 \\
1291\end{array}$ & $\begin{array}{r}4.79 \\
12.32\end{array}$ & $\begin{array}{l}4.56 \\
4.25\end{array}$ & $\begin{array}{l}0.03 \\
0.59\end{array}$ & $\begin{array}{l}36.17 \\
37.42\end{array}$ & $\begin{array}{l}641 \\
641\end{array}$ & $\begin{array}{r}8.02 \\
13.31\end{array}$ & $\begin{array}{l}4.52 \\
4.62\end{array}$ & $\begin{array}{l}3.12 \\
3.52\end{array}$ & $\begin{array}{l}36.17 \\
37.42\end{array}$ & $\begin{array}{l}0 \\
0\end{array}$ & & & & \\
\hline $\begin{array}{l}\text { Tertiary degree }(=1) \\
\text { Founder was self-employed (SE) before }(=1) \\
\text { Managerial experience as employee }(=1) \\
\text { Female founder }(=1) \\
\text { Founder of non-German origin }(=1) \\
\text { SE Subsidy by Employment Agency }(=1) \\
\text { Industry Experience (in years) } \\
\text { Age of Founder (in years) }\end{array}$ & $\begin{array}{l}1291 \\
1291 \\
1291 \\
1291 \\
1291 \\
1291 \\
1291 \\
1291\end{array}$ & $\begin{array}{r}0.28 \\
0.15 \\
0.13 \\
0.15 \\
0.06 \\
0.75 \\
17.22 \\
44.44 \\
\end{array}$ & $\begin{array}{l}0.45 \\
0.36 \\
0.33 \\
0.35 \\
0.23 \\
0.43 \\
9.52 \\
5.93\end{array}$ & $\begin{array}{r}0 \\
0 \\
0 \\
0 \\
0 \\
0 \\
1.00 \\
35.09\end{array}$ & $\begin{array}{r}1 \\
1 \\
1 \\
1 \\
1 \\
1 \\
50.00 \\
65.11\end{array}$ & $\begin{array}{l}641 \\
641 \\
641 \\
641 \\
641 \\
641 \\
641 \\
641\end{array}$ & $\begin{array}{r}0.30 \\
0.16 \\
0.14 \\
0.15 \\
0.07 \\
0.73 \\
17.00 \\
45.28\end{array}$ & $\begin{array}{r}0.46 \\
0.37 \\
0.34 \\
0.35 \\
0.25 \\
0.44 \\
10.33 \\
6.20\end{array}$ & $\begin{array}{r}0 \\
0 \\
0 \\
0 \\
0 \\
0 \\
1.00 \\
35.34\end{array}$ & $\begin{array}{r}1 \\
1 \\
1 \\
1 \\
1 \\
1 \\
50.00 \\
65.11\end{array}$ & $\begin{array}{l}1610 \\
1610 \\
1610 \\
1610 \\
1610 \\
1610 \\
1610 \\
1610\end{array}$ & $\begin{array}{r}0.35 \\
0.23 \\
0.15 \\
0.13 \\
0.05 \\
0.38 \\
16.56 \\
43.93\end{array}$ & $\begin{array}{l}0.48 \\
0.42 \\
0.36 \\
0.34 \\
0.21 \\
0.49 \\
9.15 \\
6.01\end{array}$ & $\begin{array}{r}0 \\
0 \\
0 \\
0 \\
0 \\
0 \\
1 \\
35 \\
\end{array}$ & $\begin{array}{r}1 \\
1 \\
1 \\
1 \\
1 \\
1 \\
54.00 \\
63.85\end{array}$ \\
\hline $\begin{array}{l}\text { Sales in Year } 1 \\
\text { Sales in Year } 2 \\
\text { FTE Employment after Year } 1 \\
\text { FTE Employment after Year } 2 \\
\text { Pushed/Necessity motive }(=1)\end{array}$ & $\begin{array}{r}1039 \\
851 \\
1291 \\
1272 \\
1256\end{array}$ & $\begin{array}{r}173,661 \\
231,293 \\
0.61 \\
0.85 \\
0.35\end{array}$ & $\begin{array}{r}461,647 \\
665,161 \\
1.60 \\
2.08 \\
0.48\end{array}$ & $\begin{array}{l}0 \\
0 \\
0 \\
0 \\
0\end{array}$ & $\begin{array}{r}8,123,565 \\
13,640,000 \\
16.50 \\
28.25 \\
1\end{array}$ & $\begin{array}{l}507 \\
409 \\
641 \\
628 \\
631\end{array}$ & $\begin{array}{r}134,149 \\
212,599 \\
0.39 \\
0.54 \\
0.39\end{array}$ & $\begin{array}{r}451,385 \\
830,844 \\
1.26 \\
1.44 \\
0.49\end{array}$ & $\begin{array}{l}0 \\
0 \\
0 \\
0 \\
0\end{array}$ & $\begin{array}{r}8,123,565 \\
13,640,000 \\
13.00 \\
12.50 \\
1\end{array}$ & $\begin{array}{l}1309 \\
1067 \\
1610 \\
1597 \\
1531\end{array}$ & $\begin{array}{r}399,872 \\
400,055 \\
1.02 \\
1.45 \\
0.21\end{array}$ & $\begin{array}{r}2,467,627 \\
1,121,272 \\
3.28 \\
4.26 \\
0.41\end{array}$ & $\begin{array}{l}0 \\
0 \\
0 \\
0 \\
0\end{array}$ & $\begin{array}{r}84,370,000 \\
24,180,000 \\
74.50 \\
95.75 \\
1\end{array}$ \\
\hline $\begin{array}{l}\text { Technology-intensive services } \\
\text { High-technology manufacturing } \\
\text { Skill-intensive services } \\
\text { Software supply and consultancy }\end{array}$ & $\begin{array}{l}1291 \\
1291 \\
1291 \\
1291\end{array}$ & $\begin{array}{l}0.19 \\
0.09 \\
0.05 \\
0.03\end{array}$ & $\begin{array}{l}0.39 \\
0.28 \\
0.21 \\
0.18\end{array}$ & $\begin{array}{l}0 \\
0 \\
0 \\
0\end{array}$ & $\begin{array}{l}1 \\
1 \\
1 \\
1\end{array}$ & $\begin{array}{l}641 \\
641 \\
641 \\
641\end{array}$ & $\begin{array}{l}0.20 \\
0.08 \\
0.05 \\
0.03\end{array}$ & $\begin{array}{l}0.40 \\
0.28 \\
0.22 \\
0.18\end{array}$ & $\begin{array}{l}0 \\
0 \\
0 \\
0\end{array}$ & $\begin{array}{l}1 \\
1 \\
1 \\
1\end{array}$ & $\begin{array}{l}1610 \\
1610 \\
1610 \\
1610\end{array}$ & $\begin{array}{l}0.23 \\
0.12 \\
0.08 \\
0.06\end{array}$ & $\begin{array}{l}0.42 \\
0.33 \\
0.27 \\
0.23\end{array}$ & $\begin{array}{l}0 \\
0 \\
0 \\
0\end{array}$ & $\begin{array}{l}1 \\
1 \\
1 \\
1\end{array}$ \\
\hline $\begin{array}{l}\text { Non-high-tech manufacturing } \\
\text { Other business-oriented services } \\
\text { Cons.-or. services in creative sect. }\end{array}$ & $\begin{array}{l}1291 \\
1291 \\
1291\end{array}$ & $\begin{array}{l}0.12 \\
0.07 \\
0.02\end{array}$ & $\begin{array}{l}0.33 \\
0.25 \\
0.15\end{array}$ & $\begin{array}{l}0 \\
0 \\
0\end{array}$ & $\begin{array}{l}1 \\
1 \\
1\end{array}$ & $\begin{array}{l}641 \\
641 \\
641\end{array}$ & $\begin{array}{l}0.11 \\
0.07 \\
0.02\end{array}$ & $\begin{array}{l}0.31 \\
0.25 \\
0.15\end{array}$ & $\begin{array}{l}0 \\
0 \\
0\end{array}$ & $\begin{array}{l}1 \\
1 \\
1\end{array}$ & $\begin{array}{l}1610 \\
1610 \\
1610\end{array}$ & $\begin{array}{l}0.12 \\
0.05 \\
0.03\end{array}$ & $\begin{array}{l}0.33 \\
0.22 \\
0.16\end{array}$ & $\begin{array}{l}0 \\
0 \\
0\end{array}$ & $\begin{array}{l}1 \\
1 \\
1\end{array}$ \\
\hline $\begin{array}{l}\text { Consumer-oriented services } \\
\text { Construction } \\
\text { Retail \& wholesale }\end{array}$ & $\begin{array}{l}1291 \\
1291 \\
1291\end{array}$ & $\begin{array}{l}0.10 \\
0.16 \\
0.18\end{array}$ & $\begin{array}{l}0.30 \\
0.36 \\
0.38\end{array}$ & $\begin{array}{l}0 \\
0 \\
0\end{array}$ & $\begin{array}{l}1 \\
1 \\
1\end{array}$ & $\begin{array}{l}641 \\
641 \\
641\end{array}$ & $\begin{array}{l}0.10 \\
0.15 \\
0.19\end{array}$ & $\begin{array}{l}0.30 \\
0.35 \\
0.39\end{array}$ & $\begin{array}{l}0 \\
0 \\
0\end{array}$ & $\begin{array}{l}1 \\
1 \\
1\end{array}$ & $\begin{array}{l}1610 \\
1610 \\
1610\end{array}$ & $\begin{array}{l}0.07 \\
0.11 \\
0.14\end{array}$ & $\begin{array}{l}0.25 \\
0.31 \\
0.35\end{array}$ & $\begin{array}{l}0 \\
0 \\
0\end{array}$ & $\begin{array}{l}1 \\
1 \\
1\end{array}$ \\
\hline
\end{tabular}

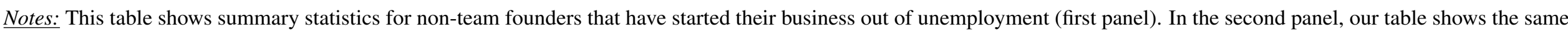

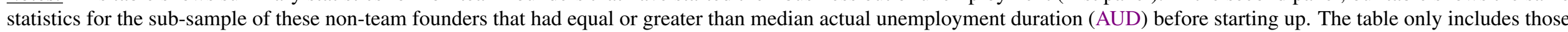

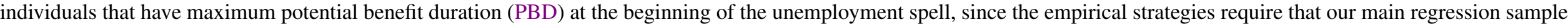

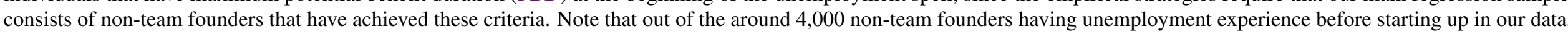

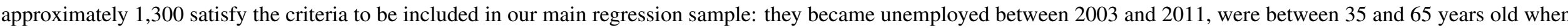

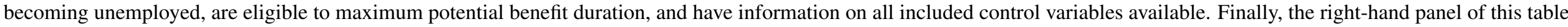
shows the same summary statistics for a reference group of founders who have started their business out of employment, i.e. they have not been previously unemployed. 
Table 2: Definition of Necessity/Pushed vs. Opportunity Founders for Regression Sample

\begin{tabular}{lrr} 
Motive to become entrepreneur & Opportunity entrepreneur & Pushed entrepreneur \\
\hline Self-determined working & 527 & 0 \\
Realisation of business idea & 255 & 0 \\
Better earning potential & 32 & 0 \\
Tax incentives & 3 & 0 \\
\hline No suitable employment options & 0 & 169 \\
Escape from unemployment & 0 & 260 \\
Forced by former employer & 0 & 10 \\
\hline Total & 817 & 439 \\
\hline
\end{tabular}

Notes: This table is based on information from the IAB/ZEW Start-Up Panel and shows only our main regression sample. 1,300 non-team founders with maximal UI potential benefit duration that have been previously unemployed are considered in this table (see the definition of our main estimation sample in Table 1). Founders are asked about their motivation for starting a firm during the survey interview that is conducted when they enter the panel for the first time. Note that the intuition behind using the term pushed entrepreneur can be well understood by checking the spikes of the exit rate from unemployment into self-employment split by the motivation to start up, which is shown in Figure A.1. This is corroborated when looking at Table 1: Previously employed founders are much less likely to feel pushed into entrepreneurship ( $21 \%$ vs. $35 \%$ for previously unemployed founders).

Table 3: Examples of Startups included in the Industry Classification

\begin{tabular}{|c|c|}
\hline Industry Classification & Examples \\
\hline Technology-intensive services & $\begin{array}{l}\text { Computer facility management, web hosting; } \\
\text { architecture and engineering consulting; technical testing/analysis }\end{array}$ \\
\hline High-technology manufacturing & $\begin{array}{l}\text { Manufacturing of glass, optical instruments, photographic equipment, } \\
\text { manufacturing of electric lighting/electrical equipment, } \\
\text { manufacturing of other pumps/compressors/metal forming machinery }\end{array}$ \\
\hline Skill-intensive services & Tax consulting, bookkeeping; consulting; market/opinion polling \\
\hline Software supply and consultancy & Programmers \\
\hline Non-high-tech manufacturing & $\begin{array}{l}\text { Breweries, textile companies, manufacturing of shoe-ware; } \\
\text { copy-shops, printing; furniture, jewellery; installation of machinery }\end{array}$ \\
\hline Other business-oriented services & $\begin{array}{l}\text { Warehouses; postal/courier activities; renting vehicles; } \\
\text { translators, human resources; landscape services }\end{array}$ \\
\hline Cons.-or. services in creative sect. & Publishers, photographers, driving schools \\
\hline Consumer-oriented services & $\begin{array}{l}\text { Taxis; restaurants/mobile food service; repair services (computer); } \\
\text { hairdressers; gambling and betting activities, insurance vendors }\end{array}$ \\
\hline Construction & Electrical installations, floor and wall covering, painting and glazing \\
\hline Retail \& wholesale & Sales of cars, wholesale (flowers, fruit, bicycle), retail sales \\
\hline
\end{tabular}

Notes: This table provides examples for the type of firms that are included in the ten industry classification codes for which we control in all our main regressions (compare Table 1). It illustrates that we cover a very broad set of startups and that we indeed have a comprehensive dataset of foundations in Germany. 
Table 4: OLS Results: Actual Unemployment Duration (AUD) on Motivation of Founder and Firm Outcomes

\begin{tabular}{|c|c|c|c|c|c|}
\hline & $\begin{array}{c}(1) \\
\text { Necessity Motive } \\
(=1)\end{array}$ & $\begin{array}{c}(2) \\
\text { Sales Year } 1 \\
(\log )\end{array}$ & $\begin{array}{c}(3) \\
\text { Sales Year } 2 \\
(\log )\end{array}$ & $\begin{array}{c}(4) \\
\text { FTE Employment } \\
\text { Year } 1(\log )\end{array}$ & $\begin{array}{c}(5) \\
\text { FTE Employmen } \\
\text { Year } 2(\log )\end{array}$ \\
\hline Actual unemployment duration (AUD) (in months) & $\begin{array}{c}\mathbf{0 . 0 1 7}^{* * *} \\
(0.003)\end{array}$ & $\begin{array}{c}\mathbf{- 0 . 1 3 9}^{* * *} \\
(0.027)\end{array}$ & $\begin{array}{c}\mathbf{- 0 . 0 9 6}^{* * *} \\
(0.018)\end{array}$ & $\begin{array}{c}\mathbf{- 0 . 0 1 6}^{* * *} \\
(0.003)\end{array}$ & $\begin{array}{c}\mathbf{- 0 . 0 2 3}^{* * *} \\
(0.003)\end{array}$ \\
\hline Tertiary degree $(=1)$ & $\begin{array}{l}-0.050 \\
(0.032)\end{array}$ & $\begin{array}{c}-0.663^{* *} \\
(0.283)\end{array}$ & $\begin{array}{l}-0.029 \\
(0.168)\end{array}$ & $\begin{array}{l}0.076^{* *} \\
(0.034)\end{array}$ & $\begin{array}{l}0.074^{*} \\
(0.039)\end{array}$ \\
\hline Founder was self-employed before $(=1)$ & $\begin{array}{l}-0.009 \\
(0.037)\end{array}$ & $\begin{array}{c}0.031 \\
(0.336)\end{array}$ & $\begin{array}{l}-0.125 \\
(0.211)\end{array}$ & $\begin{array}{l}-0.006 \\
(0.040)\end{array}$ & $\begin{array}{l}-0.018 \\
(0.045)\end{array}$ \\
\hline Managerial experience as employee $(=1)$ & $\begin{array}{l}-0.059 \\
(0.038)\end{array}$ & $\begin{array}{c}0.169 \\
(0.350)\end{array}$ & $\begin{array}{c}0.618^{* * *} \\
(0.164)\end{array}$ & $\begin{array}{c}0.135^{* * *} \\
(0.049)\end{array}$ & $\begin{array}{c}0.173^{* * *} \\
(0.056)\end{array}$ \\
\hline Industry experience (in years) & $\begin{array}{l}0.003^{*} \\
(0.001)\end{array}$ & $\begin{array}{l}0.034^{* *} \\
(0.014)\end{array}$ & $\begin{array}{c}0.003 \\
(0.009)\end{array}$ & $\begin{array}{c}0.001 \\
(0.001)\end{array}$ & $\begin{array}{c}0.001 \\
(0.002)\end{array}$ \\
\hline Female founder $(=1)$ & $\begin{array}{c}0.013 \\
(0.039)\end{array}$ & $\begin{array}{c}-0.993^{* *} \\
(0.404)\end{array}$ & $\begin{array}{l}-0.361^{*} \\
(0.210)\end{array}$ & $\begin{array}{c}0.069 \\
(0.046)\end{array}$ & $\begin{array}{l}0.104^{* *} \\
(0.052)\end{array}$ \\
\hline Founder of non-German origin $(=1)$ & $\begin{array}{c}0.033 \\
(0.060)\end{array}$ & $\begin{array}{c}-1.758^{* * *} \\
(0.673)\end{array}$ & $\begin{array}{l}-0.509 \\
(0.418)\end{array}$ & $\begin{array}{l}-0.015 \\
(0.055)\end{array}$ & $\begin{array}{l}-0.048 \\
(0.054)\end{array}$ \\
\hline SE Subsidy by Federal Employment Agency $(=1)$ & $\begin{array}{l}0.073^{* *} \\
(0.032)\end{array}$ & $\begin{array}{l}-0.413 \\
(0.280)\end{array}$ & $\begin{array}{l}-0.289^{*} \\
(0.168)\end{array}$ & $\begin{array}{l}-0.056^{*} \\
(0.033)\end{array}$ & $\begin{array}{c}-0.086^{* *} \\
(0.037)\end{array}$ \\
\hline Industry/Year Fixed Effects & Yes & Yes & Yes & Yes & Yes \\
\hline $\begin{array}{l}\mathrm{N} \\
\mathrm{R} \text {-sq. }\end{array}$ & $\begin{array}{r}1256 \\
0.063\end{array}$ & $\begin{array}{l}1039 \\
0.122\end{array}$ & $\begin{array}{c}851 \\
0.126\end{array}$ & $\begin{array}{c}1291 \\
0.150\end{array}$ & $\begin{array}{c}1272 \\
0.158\end{array}$ \\
\hline $\begin{array}{l}\text { Mean of dependent variable } \\
\text { (abs. value for log-terms) }\end{array}$ & 0.35 & $\begin{array}{c}10.074 \\
173,661\end{array}$ & $\begin{array}{c}11.271 \\
231,293\end{array}$ & $\begin{array}{l}0.271 \\
0.605\end{array}$ & $\begin{array}{l}0.361 \\
0.847\end{array}$ \\
\hline
\end{tabular}

Notes: Robust standard errors are shown in parentheses and significance levels are indicated by: *** 1\%,**5\%,*10\%. This table shows the OLS regression of our main outcome variables (motivation for starting up; sales and employment growth after year 1,2) on the founders' actual unemployment duration (AUD) before starting up. We control for the founders' education, their previous work experience, and individual characteristics. Moreover, we include year and industry (of the startup, see Table 3) fixed effects. We also include dummies to control for the receipt of self-employment (SE) related subsidies from the Federal Employment Agency and for funding by the KfW bank (Appendix C.2). Our regression sample consists of non-team founders who became unemployed between 2003 and 2011 , who were 35 to 65 years old when becoming unemployed, and for whom information on all included control variables is available. 
Table 5: OLS Results: Actual Unemployment Duration (AUD) on Motivation of Founder and Firm Outcomes focusing on Non-Manufacturing Sector

\begin{tabular}{|c|c|c|c|c|c|}
\hline & $\begin{array}{c}(1) \\
\text { Necessity Motive } \\
(=1)\end{array}$ & $\begin{array}{l}(2) \\
\text { Sales Year } 1 \\
(\log )\end{array}$ & $\begin{array}{c}\text { (3) } \\
\text { Sales Year } 2 \\
\text { (log) }\end{array}$ & $\begin{array}{c}(4) \\
\text { FTE Employment } \\
\text { Year } 1(\log )\end{array}$ & $\begin{array}{c}(5) \\
\text { FTE Employment } \\
\text { Year } 2(\log )\end{array}$ \\
\hline Actual unemployment duration (AUD) (in months) & $\begin{array}{c}\mathbf{0 . 0 1 8}^{* * *} \\
(0.003)\end{array}$ & $\begin{array}{c}-\mathbf{- 0 . 1 2 8}^{* * *} \\
(0.029)\end{array}$ & $\begin{array}{c}-\mathbf{- 0 . 1 0 2}^{* * *} \\
(0.021)\end{array}$ & $\begin{array}{c}-\mathbf{- 0 . 0 1 6}^{* * *} \\
(0.003)\end{array}$ & $\begin{array}{c}\mathbf{- 0 . 0 2 4}^{* * *} \\
(0.003)\end{array}$ \\
\hline Tertiary degree $(=1)$ & $\begin{array}{l}-0.069^{*} \\
(0.036)\end{array}$ & $\begin{array}{c}-0.392 \\
(0.290)\end{array}$ & $\begin{array}{c}0.143 \\
(0.168)\end{array}$ & $\begin{array}{l}0.059^{*} \\
(0.035)\end{array}$ & $\begin{array}{c}0.057 \\
(0.041)\end{array}$ \\
\hline Founder was self-employed before $(=1)$ & $\begin{array}{c}0.009 \\
(0.042)\end{array}$ & $\begin{array}{c}0.119 \\
(0.343)\end{array}$ & $\begin{array}{l}-0.262 \\
(0.230)\end{array}$ & $\begin{array}{c}0.015 \\
(0.045)\end{array}$ & $\begin{array}{c}0.031 \\
(0.051)\end{array}$ \\
\hline Managerial experience as employee $(=1)$ & $\begin{array}{c}-0.096^{* *} \\
(0.042)\end{array}$ & $\begin{array}{c}0.022 \\
(0.381)\end{array}$ & $\begin{array}{l}0.457^{* *} \\
(0.184)\end{array}$ & $\begin{array}{l}0.130^{* *} \\
(0.053)\end{array}$ & $\begin{array}{c}0.178^{* * *} \\
(0.060)\end{array}$ \\
\hline Industry experience (in years) & $\begin{array}{c}0.002 \\
(0.002)\end{array}$ & $\begin{array}{c}0.021 \\
(0.015)\end{array}$ & $\begin{array}{c}0.001 \\
(0.011)\end{array}$ & $\begin{array}{c}0.002 \\
(0.002)\end{array}$ & $\begin{array}{c}0.002 \\
(0.002)\end{array}$ \\
\hline Female founder $(=1)$ & $\begin{array}{c}0.006 \\
(0.043)\end{array}$ & $\begin{array}{l}-0.693^{*} \\
(0.413)\end{array}$ & $\begin{array}{c}-0.512^{* *} \\
(0.232)\end{array}$ & $\begin{array}{c}0.077 \\
(0.051)\end{array}$ & $\begin{array}{l}0.096^{*} \\
(0.056)\end{array}$ \\
\hline Founder of non-German origin $(=1)$ & $\begin{array}{l}-0.047 \\
(0.064)\end{array}$ & $\begin{array}{c}-1.820^{* *} \\
(0.724)\end{array}$ & $\begin{array}{l}-0.843^{*} \\
(0.496)\end{array}$ & $\begin{array}{l}-0.076 \\
(0.047)\end{array}$ & $\begin{array}{l}-0.080^{*} \\
(0.047)\end{array}$ \\
\hline SE Subsidy by Federal Employment Agency $(=1)$ & $\begin{array}{l}0.070^{*} \\
(0.036) \\
\end{array}$ & $\begin{array}{c}-0.629^{* *} \\
(0.309) \\
\end{array}$ & $\begin{array}{l}-0.277 \\
(0.202)\end{array}$ & $\begin{array}{l}-0.054 \\
(0.035) \\
\end{array}$ & $\begin{array}{l}-0.069^{*} \\
(0.040)\end{array}$ \\
\hline Industry/Year Fixed Effects & Yes & Yes & Yes & Yes & Yes \\
\hline $\begin{array}{l}\mathrm{N} \\
\mathrm{R} \text {-sq. }\end{array}$ & $\begin{array}{c}999 \\
0.076\end{array}$ & $\begin{array}{c}815 \\
0.103 \\
\end{array}$ & $\begin{array}{c}661 \\
0.145 \\
\end{array}$ & $\begin{array}{l}1022 \\
0.167\end{array}$ & $\begin{array}{l}1009 \\
0.168\end{array}$ \\
\hline $\begin{array}{l}\text { Mean of dependent variable } \\
\text { (abs. value for log-terms) }\end{array}$ & 0.352 & $\begin{array}{c}10.21 \\
179,344\end{array}$ & $\begin{array}{c}11.251 \\
237,112\end{array}$ & $\begin{array}{c}0.25 \\
0.549\end{array}$ & $\begin{array}{c}0.329 \\
0.76\end{array}$ \\
\hline
\end{tabular}

Notes: Robust standard errors are shown in parentheses and significance levels are indicated by: *** 1\%,** 5\%,* $10 \%$. This table shows the OLS regression of our main outcome variables (motivation for starting up; sales and employment growth after year 1,2) on the founders' actual unemployment duration (AUD) before starting up in the non-manufacturing sector (75\% of our sample). We control for the founders' education, their previous work experience, and individual characteristics. Moreover, we include year and industry (of the startup, see Table 3) fixed effects. We also include dummies to control for the receipt of self-employment (SE) related subsidies from the Federal Employment Agency and for funding by the KfW bank (Appendix C.2). Our regression sample consists of non-team founders who became unemployed between 2003 and 2011, who were 35 to 65 years old when becoming unemployed, and for whom information on all included control variables is available. 
Table 6: Potential UI Benefit Duration (in months) based on Contributions/Age

\begin{tabular}{|c|c|c|c|c|c|c|}
\hline (1) & (2) & (3) & (4) & (5) & (6) & (7) \\
\hline Contribution & before & Age & from $02 / 2006$ & Age & since & Age \\
\hline Months & $02 / 2006$ & Rules & until $12 / 2007$ & Rules & $01 / 2008$ & Rules \\
\hline 12 & 6 & & 6 & & 6 & \\
\hline 18 & 9 & & 9 & & 9 & \\
\hline 24 & 12 & & 12 & & 12 & \\
\hline 30 & 15 & $\geq 45$ & 15 & $\geq 55$ & 15 & $\geq 50$ \\
\hline 36 & 18 & & 18 & $\geq 55$ & 18 & $\geq 55$ \\
\hline 44 & 22 & $\geq 47$ & 18 & $\geq 55$ & 22 & $\geq 58$ \\
\hline 48 & 24 & & 18 & $\geq 55$ & 24 & $\geq 58$ \\
\hline 52 & 26 & $\geq 52$ & 18 & $\geq 55$ & 24 & $\geq 58$ \\
\hline 64 & 32 & $\geq 57$ & 18 & $\geq 55$ & 24 & $\geq 58$ \\
\hline
\end{tabular}

Notes: The table shows how potential unemployment insurance (UI) benefit duration (PBD) varies with the number of contribution months (column 1), i.e. the number of months a worker paid UI contributions that are mandatory for jobs covered by the social security. The rules state that after having satisfied the minimum eligibility requirement (e.g. at least 12 contributions within last 24 months) half of the number of contribution months translate into PBD. However, at some point a maximum PBD is reached and additional contribution months can no longer increase PBD. This table presents the age rules for maximum PBD, i.e. for which age groups the indicated PBD is available, since only with increasing age does the maximum PBD increase. Maximum PBD by age group is also shown in Table 7. Columns (2) and (3) show the PBD regime before February 2006, columns (4) and (5) between February 2006 and December 2007 and columns (6) and (7) since January 2008.

Table 7: Maximum Potential UI Benefit Duration (in months) in Germany

\begin{tabular}{|c|c|c|c|c|c|c|}
\hline $\begin{array}{c}\text { (1) } \\
\text { Age }\end{array}$ & $\begin{array}{c}(2) \\
\text { before } \\
02 / 2006\end{array}$ & $\begin{array}{c}\text { (3) } \\
\text { Reduction } \\
\text { in months }\end{array}$ & $\begin{array}{l}(4) \\
\text { from } 02 / 2006 \\
\text { until } 12 / 2007\end{array}$ & $\begin{array}{c}\text { (5) } \\
\text { Extension } \\
\text { in months }\end{array}$ & $\begin{array}{c}(6) \\
\text { since } \\
01 / 2008\end{array}$ & $\begin{array}{c}(7) \\
\text { Net-Effect } \\
\text { in months }\end{array}$ \\
\hline$<45$ & 12 & 0 & 12 & 0 & 12 & 0 \\
\hline $45-46$ & 18 & -6 & 12 & 0 & 12 & -6 \\
\hline $47-49$ & 22 & -10 & 12 & 0 & 12 & -10 \\
\hline $50-51$ & 22 & -10 & 12 & +3 & 15 & -7 \\
\hline $52-54$ & 26 & -14 & 12 & +3 & 15 & -11 \\
\hline $55-56$ & 26 & -8 & 18 & 0 & 18 & -8 \\
\hline 57 & 32 & -14 & 18 & 0 & 18 & -14 \\
\hline$>58$ & 32 & -14 & 18 & +6 & 24 & -8 \\
\hline
\end{tabular}

Notes: The table shows how potential unemployment insurance (UI) benefit duration (PBD) varies by age group and over time for unemployed individuals who had worked for at least the number of contribution months within the last five years (seven years before 02/2006) necessary to get the maximum PBD of their age group according to Table 6 without intermittent UI spell. This table shows that the reform of February 2006 represents a considerable decline in PBD for workers aged above 45 years. In contrast, the reform of January 2008 partially increased PBD again. However, in total the net effect across both reforms demonstrates that all age groups beyond 45 years suffered a considerable decline in PBD (cf. Section 3). 
Table 8: OLS Results: Potential Benefit Duration (PBD) on Actual Unemployment Duration (AUD), Motivation of Founder, and Firm Outcomes

\begin{tabular}{|c|c|c|c|c|c|c|}
\hline & $\begin{array}{c}(1) \\
\text { AUD } \\
\text { (in months) }\end{array}$ & $\begin{array}{c}(2) \\
\text { Necessity Motive } \\
(=1)\end{array}$ & $\begin{array}{c}(3) \\
\text { Sales Year } 1 \\
(\log )\end{array}$ & $\begin{array}{c}(4) \\
\text { Sales Year } 2 \\
(\log )\end{array}$ & $\begin{array}{c}(5) \\
\text { FTE Employment } \\
\text { Year } 1(\log )\end{array}$ & $\begin{array}{c}(6) \\
\text { FTE Employment } \\
\text { Year } 2(\log )\end{array}$ \\
\hline Potential benefit duration (PBD) (in months) & $\begin{array}{c}\mathbf{0 . 4 7 1}^{* * *} \\
(0.048)\end{array}$ & $\begin{array}{c}\mathbf{0 . 0 2 3}^{* * *} \\
(0.003)\end{array}$ & $\begin{array}{l}\mathbf{- 0 . 0 3 6} \\
(0.024)\end{array}$ & $\begin{array}{l}\mathbf{- 0 . 0 4 9 *}^{* *} \\
(0.022)\end{array}$ & $\begin{array}{l}\mathbf{- 0 . 0 0 4} \\
(0.004)\end{array}$ & $\begin{array}{c}\mathbf{- 0 . 0 0 9}^{* *} \\
(0.004)\end{array}$ \\
\hline Tertiary degree $(=1)$ & $\begin{array}{l}-0.386 \\
(0.291)\end{array}$ & $\begin{array}{c}-0.073^{* *} \\
(0.032)\end{array}$ & $\begin{array}{c}-0.636^{* *} \\
(0.289)\end{array}$ & $\begin{array}{c}0.027 \\
(0.173)\end{array}$ & $\begin{array}{l}0.079^{* *} \\
(0.034)\end{array}$ & $\begin{array}{l}0.081^{* *} \\
(0.040)\end{array}$ \\
\hline Founder was self-employed before $(=1)$ & $\begin{array}{c}0.116 \\
(0.338)\end{array}$ & $\begin{array}{l}-0.014 \\
(0.037)\end{array}$ & $\begin{array}{l}-0.001 \\
(0.341)\end{array}$ & $\begin{array}{l}-0.095 \\
(0.213)\end{array}$ & $\begin{array}{l}-0.009 \\
(0.040)\end{array}$ & $\begin{array}{l}-0.019 \\
(0.045)\end{array}$ \\
\hline Managerial experience as employee $(=1)$ & $\begin{array}{l}-0.004 \\
(0.346)\end{array}$ & $\begin{array}{c}-0.069^{*} \\
(0.038)\end{array}$ & $\begin{array}{c}0.160 \\
(0.356)\end{array}$ & $\begin{array}{c}0.609^{* * *} \\
(0.168)\end{array}$ & $\begin{array}{c}0.134^{* * *} \\
(0.050)\end{array}$ & $\begin{array}{c}0.173^{* * *} \\
(0.057)\end{array}$ \\
\hline Industry experience (in years) & $\begin{array}{l}-0.013 \\
(0.015)\end{array}$ & $\begin{array}{c}0.001 \\
(0.001)\end{array}$ & $\begin{array}{l}0.036^{* *} \\
(0.014)\end{array}$ & $\begin{array}{c}0.007 \\
(0.009)\end{array}$ & $\begin{array}{c}0.001 \\
(0.002)\end{array}$ & $\begin{array}{c}0.002 \\
(0.002)\end{array}$ \\
\hline Female founder $(=1)$ & $\begin{array}{c}0.176 \\
(0.326)\end{array}$ & $\begin{array}{c}0.013 \\
(0.039)\end{array}$ & $\begin{array}{c}-1.075^{* * *} \\
(0.405)\end{array}$ & $\begin{array}{l}-0.369^{*} \\
(0.221)\end{array}$ & $\begin{array}{l}0.065 \\
(0.047)\end{array}$ & $\begin{array}{l}0.100^{*} \\
(0.053)\end{array}$ \\
\hline Founder of non-German origin $(=1)$ & $\begin{array}{c}0.299 \\
(0.500)\end{array}$ & $\begin{array}{c}0.034 \\
(0.059)\end{array}$ & $\begin{array}{c}-1.853^{* * *} \\
(0.674)\end{array}$ & $\begin{array}{l}-0.553 \\
(0.446)\end{array}$ & $\begin{array}{l}-0.021 \\
(0.056)\end{array}$ & $\begin{array}{l}-0.056 \\
(0.057)\end{array}$ \\
\hline SE Subsidy by Federal Employment Agency $(=1)$ & $\begin{array}{l}-0.301 \\
(0.292)\end{array}$ & $\begin{array}{l}0.061^{*} \\
(0.031)\end{array}$ & $\begin{array}{l}-0.401 \\
(0.281)\end{array}$ & $\begin{array}{l}-0.277 \\
(0.171)\end{array}$ & $\begin{array}{l}-0.053 \\
(0.034)\end{array}$ & $\begin{array}{c}-0.080^{* *} \\
(0.038)\end{array}$ \\
\hline Industry/Year Fixed Effects & Yes & Yes & Yes & Yes & Yes & Yes \\
\hline $\begin{array}{l}\mathrm{N} \\
\mathrm{R} \text {-sq. }\end{array}$ & $\begin{array}{l}1291 \\
0.256\end{array}$ & $\begin{array}{l}1256 \\
0.077\end{array}$ & $\begin{array}{l}1039 \\
0.099\end{array}$ & $\begin{array}{c}851 \\
0.096\end{array}$ & $\begin{array}{l}1291 \\
0.133\end{array}$ & $\begin{array}{l}1272 \\
0.134\end{array}$ \\
\hline $\begin{array}{l}\text { Mean of dependent variable } \\
\text { (abs. value for log-terms) }\end{array}$ & 4.785 & 0.35 & $\begin{array}{c}10.074 \\
173,661\end{array}$ & $\begin{array}{c}11.271 \\
231,293\end{array}$ & $\begin{array}{l}0.271 \\
0.605\end{array}$ & $\begin{array}{l}0.361 \\
0.847\end{array}$ \\
\hline
\end{tabular}

Notes: Robust standard errors are shown in parentheses and significance levels are indicated by: *** $1 \%, * * 5 \%, * 10 \%$. This table shows the OLS regression of our main outcome variables (actual unemployment duration (AUD), motivation for starting up; sales and employment growth after year 1,2) on the founders' potential benefit duration (PBD) before starting up. We control for the founders' education, their previous work experience, and individual characteristics. Moreover, we include year and industry (of the startup, see Table 3) fixed effects. We also include dummies to control for the receipt of self-employment (SE) related subsidies from the Federal Employment Agency and for funding by the KfW bank (Appendix C.2). Our regression sample consists of non-team founders who became unemployed between 2003 and 2011, who were 35 to 65 years old when becoming unemployed, and for whom information on all included control variables is available. 
Table 9: OLS Results: Potential Benefit Duration on Actual Unemployment Duration, Motivation of Founder, and Firm Outcomes for Non-Manufacturing Sector

\begin{tabular}{|c|c|c|c|c|c|c|}
\hline & $\begin{array}{c}\text { (1) } \\
\text { AUD } \\
\text { (in months) }\end{array}$ & $\begin{array}{c}(2) \\
\text { Necessity Motive } \\
(=1)\end{array}$ & $\begin{array}{c}(3) \\
\text { Sales Year } 1 \\
(\log )\end{array}$ & $\begin{array}{c}(4) \\
\text { Sales Year } 2 \\
(\log )\end{array}$ & $\begin{array}{c}(5) \\
\text { FTE Employment } \\
\text { Year } 1(\log )\end{array}$ & $\begin{array}{c}(6) \\
\text { FTE Employment } \\
\text { Year } 2(\log )\end{array}$ \\
\hline Potential benefit duration (PBD) (in months) & $\begin{array}{c}\mathbf{0 . 4 8 4}^{* * *} \\
(0.053)\end{array}$ & $\begin{array}{c}\mathbf{0 . 0 2 2}^{* * *} \\
(0.004)\end{array}$ & $\begin{array}{c}-\mathbf{- 0 . 0 6 7} 7^{* * *} \\
(0.026)\end{array}$ & $\begin{array}{c}-\mathbf{- 0 . 0 7 0}^{* * *} \\
(0.026)\end{array}$ & $\begin{array}{c}-\mathbf{- 0 . 0 1 0}{ }^{* * *} \\
(0.003)\end{array}$ & $\begin{array}{c}\mathbf{- 0 . 0 1 5}^{\text {*** }} \\
(0.004)\end{array}$ \\
\hline Tertiary degree $(=1)$ & $\begin{array}{c}-0.462 \\
(0.335)\end{array}$ & $\begin{array}{c}-0.092^{* * *} \\
(0.036)\end{array}$ & $\begin{array}{l}-0.324 \\
(0.295)\end{array}$ & $\begin{array}{c}0.225 \\
(0.168)\end{array}$ & $\begin{array}{l}0.069^{*} \\
(0.036)\end{array}$ & $\begin{array}{l}0.072^{*} \\
(0.041)\end{array}$ \\
\hline Founder was self-employed before $(=1)$ & $\begin{array}{c}0.443 \\
(0.369)\end{array}$ & $\begin{array}{c}0.015 \\
(0.042)\end{array}$ & $\begin{array}{c}0.065 \\
(0.351)\end{array}$ & $\begin{array}{l}-0.250 \\
(0.235)\end{array}$ & $\begin{array}{c}0.008 \\
(0.046)\end{array}$ & $\begin{array}{c}0.023 \\
(0.052)\end{array}$ \\
\hline Managerial experience as employee $(=1)$ & $\begin{array}{c}0.052 \\
(0.387)\end{array}$ & $\begin{array}{c}-0.098^{* *} \\
(0.043)\end{array}$ & $\begin{array}{c}0.005 \\
(0.383)\end{array}$ & $\begin{array}{l}0.430^{* *} \\
(0.188)\end{array}$ & $\begin{array}{l}0.130^{* *} \\
(0.053)\end{array}$ & $\begin{array}{c}0.178^{* * *} \\
(0.061)\end{array}$ \\
\hline Industry experience (in years) & $\begin{array}{c}0.001 \\
(0.016)\end{array}$ & $\begin{array}{c}0.001 \\
(0.002)\end{array}$ & $\begin{array}{c}0.022 \\
(0.015)\end{array}$ & $\begin{array}{c}0.005 \\
(0.011)\end{array}$ & $\begin{array}{c}0.002 \\
(0.002)\end{array}$ & $\begin{array}{c}0.003 \\
(0.002)\end{array}$ \\
\hline Female founder $(=1)$ & $\begin{array}{c}0.329 \\
(0.370)\end{array}$ & $\begin{array}{c}0.007 \\
(0.043)\end{array}$ & $\begin{array}{l}-0.787^{*} \\
(0.415)\end{array}$ & $\begin{array}{c}-0.539^{* *} \\
(0.244)\end{array}$ & $\begin{array}{c}0.072 \\
(0.052)\end{array}$ & $\begin{array}{c}0.090 \\
(0.057)\end{array}$ \\
\hline Founder of non-German origin $(=1)$ & $\begin{array}{c}0.303 \\
(0.546)\end{array}$ & $\begin{array}{l}-0.040 \\
(0.065)\end{array}$ & $\begin{array}{c}-1.882^{* * *} \\
(0.723)\end{array}$ & $\begin{array}{l}-0.876 \\
(0.533)\end{array}$ & $\begin{array}{l}-0.081^{*} \\
(0.047)\end{array}$ & $\begin{array}{l}-0.088^{*} \\
(0.049)\end{array}$ \\
\hline SE Subsidy by Federal Employment Agency $(=1)$ & $\begin{array}{l}-0.287 \\
(0.342) \\
\end{array}$ & $\begin{array}{l}0.062^{*} \\
(0.036) \\
\end{array}$ & $\begin{array}{l}-0.597^{*} \\
(0.310) \\
\end{array}$ & $\begin{array}{c}-0.252 \\
(0.202) \\
\end{array}$ & $\begin{array}{l}-0.049 \\
(0.036) \\
\end{array}$ & $\begin{array}{l}-0.060 \\
(0.041) \\
\end{array}$ \\
\hline Industry/Year Fixed Effects & Yes & Yes & Yes & Yes & Yes & Yes \\
\hline $\begin{array}{l}\mathrm{N} \\
\mathrm{R} \text {-sq. }\end{array}$ & $\begin{array}{l}1022 \\
0.266\end{array}$ & $\begin{array}{c}999 \\
0.082 \\
\end{array}$ & $\begin{array}{c}815 \\
0.085 \\
\end{array}$ & $\begin{array}{c}661 \\
0.116 \\
\end{array}$ & $\begin{array}{l}1022 \\
0.153\end{array}$ & $\begin{array}{l}1009 \\
0.145\end{array}$ \\
\hline $\begin{array}{l}\text { Mean of dependent variable } \\
\text { (abs. value for log-terms) }\end{array}$ & 4.895 & 0.352 & $\begin{array}{c}10.21 \\
179,344\end{array}$ & $\begin{array}{c}11.251 \\
237,112\end{array}$ & $\begin{array}{c}0.25 \\
0.549\end{array}$ & $\begin{array}{c}0.329 \\
0.76\end{array}$ \\
\hline
\end{tabular}

Notes: Robust standard errors are shown in parentheses and significance levels are indicated by: $* * * 1 \%, * * 5 \%, * 10 \%$. This table shows the OLS regression of our main outcome variables (actual unemployment duration (AUD), motivation for starting up; sales and employment growth after year 1,2) on the founders' potential benefit duration (PBD) before starting up in the non-manufacturing sector ( $75 \%$ of our sample). We control for the founders' education, their previous work experience, and individual characteristics. Moreover, we include year and industry (of the startup, see Table 3) fixed effects. We also include dummies to control for the receipt of self-employment (SE) related subsidies from the Federal Employment Agency and for funding by the KfW bank (Appendix C.2). Our regression sample consists of non-team founders who became unemployed between 2003 and 2011, who were 35 to 65 years old when becoming unemployed, and for whom information on all included control variables is available. 
Table 10: IV Results for Reform 2006: Potential Benefit Duration (PBD) on Actual Unemployment Duration (AUD), Motivation of Founder, and Firm Outcomes

\begin{tabular}{|c|c|c|c|c|c|c|c|}
\hline & $\begin{array}{c}\text { (1) } \\
\text { PBD } \\
\text { (in months) }\end{array}$ & $\begin{array}{c}\text { (2) } \\
\text { AUD } \\
\text { (in months) }\end{array}$ & $\begin{array}{c}(3) \\
\text { Necessity Motive } \\
(=1)\end{array}$ & $\begin{array}{l}(4) \\
\text { Sales Year } 1 \\
(\log )\end{array}$ & $\begin{array}{l}(5) \\
\text { Sales Year } 2 \\
\quad(\log )\end{array}$ & $\begin{array}{c}(6) \\
\text { FTE Employment } \\
\text { Year } 1(\log )\end{array}$ & $\begin{array}{c}(7) \\
\text { FTE Employment } \\
\text { Year } 2(\log )\end{array}$ \\
\hline Potential benefit duration (PBD) (in months) & & $\begin{array}{l}\mathbf{0 . 6 6 1}^{* * *} \\
(0.094)\end{array}$ & $\begin{array}{l}\mathbf{0 . 0 1 5}^{* *} \\
(0.007)\end{array}$ & $\begin{array}{c}\mathbf{0 . 0 3 4} \\
(0.052)\end{array}$ & $\begin{array}{l}\mathbf{- 0 . 0 7 2}{ }^{*} \\
(0.039)\end{array}$ & $\begin{array}{c}\mathbf{0 . 0 0 3} \\
(0.007)\end{array}$ & $\begin{array}{l}\mathbf{- 0 . 0 0 6} \\
(0.008)\end{array}$ \\
\hline Tertiary degree $(=1)$ & $\begin{array}{c}0.313 \\
(0.221)\end{array}$ & $\begin{array}{l}-0.513^{*} \\
(0.289)\end{array}$ & $\begin{array}{c}-0.075^{* *} \\
(0.032)\end{array}$ & $\begin{array}{c}-0.689^{* *} \\
(0.289)\end{array}$ & $\begin{array}{c}0.048 \\
(0.169)\end{array}$ & $\begin{array}{l}0.071^{* *} \\
(0.034)\end{array}$ & $\begin{array}{l}0.078^{* *} \\
(0.039)\end{array}$ \\
\hline Founder was self-employed before $(=1)$ & $\begin{array}{l}-0.025 \\
(0.278)\end{array}$ & $\begin{array}{c}0.121 \\
(0.345)\end{array}$ & $\begin{array}{l}-0.022 \\
(0.037)\end{array}$ & $\begin{array}{l}-0.014 \\
(0.339)\end{array}$ & $\begin{array}{l}-0.093 \\
(0.210)\end{array}$ & $\begin{array}{l}-0.012 \\
(0.039)\end{array}$ & $\begin{array}{l}-0.020 \\
(0.045)\end{array}$ \\
\hline Managerial experience as employee $(=1)$ & $\begin{array}{c}0.301 \\
(0.305)\end{array}$ & $\begin{array}{l}-0.023 \\
(0.348)\end{array}$ & $\begin{array}{c}-0.077^{* *} \\
(0.038)\end{array}$ & $\begin{array}{c}0.144 \\
(0.353)\end{array}$ & $\begin{array}{c}0.613^{* * *} \\
(0.165)\end{array}$ & $\begin{array}{c}0.130^{* * *} \\
(0.050)\end{array}$ & $\begin{array}{c}0.171^{* * *} \\
(0.057)\end{array}$ \\
\hline Industry experience (in years) & $\begin{array}{c}0.014 \\
(0.011)\end{array}$ & $\begin{array}{l}-0.017 \\
(0.014)\end{array}$ & $\begin{array}{c}0.001 \\
(0.001)\end{array}$ & $\begin{array}{l}0.033^{* *} \\
(0.015)\end{array}$ & $\begin{array}{c}0.009 \\
(0.010)\end{array}$ & $\begin{array}{c}0.001 \\
(0.002)\end{array}$ & $\begin{array}{c}0.001 \\
(0.002)\end{array}$ \\
\hline Female founder $(=1)$ & $\begin{array}{c}0.002 \\
(0.274)\end{array}$ & $\begin{array}{c}0.198 \\
(0.325)\end{array}$ & $\begin{array}{c}0.004 \\
(0.038)\end{array}$ & $\begin{array}{c}-1.088^{* * *} \\
(0.402)\end{array}$ & $\begin{array}{l}-0.366^{*} \\
(0.216)\end{array}$ & $\begin{array}{c}0.063 \\
(0.046)\end{array}$ & $\begin{array}{l}0.099^{*} \\
(0.052)\end{array}$ \\
\hline Founder of non-German origin $(=1)$ & $\begin{array}{c}0.021 \\
(0.372)\end{array}$ & $\begin{array}{c}0.207 \\
(0.505)\end{array}$ & $\begin{array}{c}0.042 \\
(0.058)\end{array}$ & $\begin{array}{c}-1.897^{* * *} \\
(0.666)\end{array}$ & $\begin{array}{l}-0.530 \\
(0.427)\end{array}$ & $\begin{array}{l}-0.023 \\
(0.055)\end{array}$ & $\begin{array}{l}-0.057 \\
(0.056)\end{array}$ \\
\hline SE Subsidy by Federal Employment Agency (=1) & $\begin{array}{l}0.398^{*} \\
(0.214)\end{array}$ & $\begin{array}{l}-0.406 \\
(0.294)\end{array}$ & $\begin{array}{l}0.067^{* *} \\
(0.031)\end{array}$ & $\begin{array}{l}-0.437 \\
(0.279)\end{array}$ & $\begin{array}{l}-0.269 \\
(0.167)\end{array}$ & $\begin{array}{l}-0.056^{*} \\
(0.033)\end{array}$ & $\begin{array}{c}-0.081^{* *} \\
(0.038)\end{array}$ \\
\hline IV_06 & $\begin{array}{c}\mathbf{- 8 . 7 4 3}^{* * *} \\
(0.505)\end{array}$ & & & & & & \\
\hline Industry/Year Fixed Effects & Yes & Yes & Yes & Yes & Yes & Yes & Yes \\
\hline $\begin{array}{l}\text { First-stage F-statistic } \\
\mathrm{N} \\
\mathrm{R} \text {-sq. }\end{array}$ & $\begin{array}{c}1291 \\
0.470\end{array}$ & $\begin{array}{c}299.421 \\
1291 \\
0.234 \\
\end{array}$ & $\begin{array}{c}286.66 \\
1256 \\
0.083\end{array}$ & $\begin{array}{c}223.603 \\
1039 \\
0.094 \\
\end{array}$ & $\begin{array}{c}220.761 \\
851 \\
0.094 \\
\end{array}$ & $\begin{array}{c}299.421 \\
1291 \\
0.130 \\
\end{array}$ & $\begin{array}{c}296.11 \\
1272 \\
0.134\end{array}$ \\
\hline $\begin{array}{l}\text { Mean of dependent variable } \\
\text { (abs. value for log-terms) }\end{array}$ & 12.324 & 4.785 & 0.35 & $\begin{array}{c}10.074 \\
173,661\end{array}$ & $\begin{array}{c}11.271 \\
231,293\end{array}$ & $\begin{array}{l}0.271 \\
0.605\end{array}$ & $\begin{array}{l}0.361 \\
0.847\end{array}$ \\
\hline
\end{tabular}

Notes: Standard errors are shown in parentheses and significance levels are indicated by: *** 1\%,** 5\%,*10\%. This table shows the IV regression of our outcome variables (AUD, motivation for starting up; sales/employment growth after year 1,2) on the founders' PBD before starting up that is instrumented by IV06 (Section 3.2). Column 1 shows the first-stage regression of the IV model in column 2. We control for the founders' education, previous work experience, and individual characteristics. We include year and industry (of the startup, see Table 3) fixed effects, and dummies to control for the receipt of self-employment (SE) related subsidies from the Federal Employment Agency and for funding by the KfW (Appendix C.2). Our regression sample consists of non-team founders who became unemployed between 2003 and 2011, were 35 to 65 years old when becoming unemployed, and for whom information on all control variables is available. 
Table 11: IV Results for Reform 2006: PBD on Actual Unemployment Duration, Motivation of Founder, Firm Outcomes for Non-Manufacturing Sector

\begin{tabular}{|c|c|c|c|c|c|c|c|}
\hline & $\begin{array}{c}(1) \\
\text { PBD } \\
\text { (in months) }\end{array}$ & $\begin{array}{c}(2) \\
\text { AUD } \\
\text { (in months) }\end{array}$ & $\begin{array}{c}(3) \\
\text { Necessity Motive } \\
(=1)\end{array}$ & $\begin{array}{c}(4) \\
\text { Sales Year } 1 \\
(\log )\end{array}$ & $\begin{array}{c}(5) \\
\text { Sales Year } 2 \\
(\log )\end{array}$ & $\begin{array}{l}\qquad(6) \\
\text { FTE Employment } \\
\text { Year } 1(\log )\end{array}$ & $\begin{array}{l}(7) \\
\text { FTE Employment } \\
\text { Year } 2(\log )\end{array}$ \\
\hline Potential benefit duration (PBD) (in months) & & $\begin{array}{c}\mathbf{0 . 7 2 2}^{* * *} \\
(0.109)\end{array}$ & $\begin{array}{c}\mathbf{0 . 0 1 0} \\
(0.008)\end{array}$ & $\begin{array}{c}\mathbf{0 . 0 0 4} \\
(0.056)\end{array}$ & $\begin{array}{c}\mathbf{- 0 . 1 1 5}^{* *} \\
(0.051)\end{array}$ & $\begin{array}{l}-\mathbf{- 0 . 0 0 8} \\
(0.006)\end{array}$ & $\begin{array}{c}-\mathbf{- 0 . 0 1 8}^{* *} \\
(0.008)\end{array}$ \\
\hline Tertiary degree $(=1)$ & $\begin{array}{c}0.434^{*} \\
(0.248)\end{array}$ & $\begin{array}{l}-0.641^{*} \\
(0.331)\end{array}$ & $\begin{array}{c}-0.089^{* *} \\
(0.036)\end{array}$ & $\begin{array}{c}-0.390 \\
(0.296)\end{array}$ & $\begin{array}{c}0.269 \\
(0.167)\end{array}$ & $\begin{array}{c}0.064^{*} \\
(0.036)\end{array}$ & $\begin{array}{c}0.071^{*} \\
(0.041)\end{array}$ \\
\hline Founder was self-employed before $(=1)$ & $\begin{array}{l}-0.296 \\
(0.312)\end{array}$ & $\begin{array}{c}0.517 \\
(0.385)\end{array}$ & $\begin{array}{c}0.006 \\
(0.042)\end{array}$ & $\begin{array}{c}0.078 \\
(0.350)\end{array}$ & $\begin{array}{l}-0.270 \\
(0.234)\end{array}$ & $\begin{array}{c}0.005 \\
(0.044)\end{array}$ & $\begin{array}{c}0.019 \\
(0.051)\end{array}$ \\
\hline Managerial experience as employee $(=1)$ & $\begin{array}{c}0.137 \\
(0.350)\end{array}$ & $\begin{array}{c}0.068 \\
(0.387)\end{array}$ & $\begin{array}{c}-0.105^{* *} \\
(0.042)\end{array}$ & $\begin{array}{l}-0.000 \\
(0.377)\end{array}$ & $\begin{array}{l}0.423^{* *} \\
(0.186)\end{array}$ & $\begin{array}{l}0.127^{* *} \\
(0.053)\end{array}$ & $\begin{array}{c}0.176^{* * *} \\
(0.060)\end{array}$ \\
\hline Industry experience (in years) & $\begin{array}{c}0.011 \\
(0.013)\end{array}$ & $\begin{array}{c}-0.006 \\
(0.016)\end{array}$ & $\begin{array}{c}0.001 \\
(0.002)\end{array}$ & $\begin{array}{c}0.019 \\
(0.016)\end{array}$ & $\begin{array}{c}0.008 \\
(0.012)\end{array}$ & $\begin{array}{c}0.002 \\
(0.002)\end{array}$ & $\begin{array}{c}0.002 \\
(0.002)\end{array}$ \\
\hline Female founder $(=1)$ & $\begin{array}{c}0.086 \\
(0.313)\end{array}$ & $\begin{array}{c}0.312 \\
(0.368)\end{array}$ & $\begin{array}{c}0.001 \\
(0.042)\end{array}$ & $\begin{array}{c}-0.818^{* *} \\
(0.412)\end{array}$ & $\begin{array}{c}-0.533^{* *} \\
(0.238)\end{array}$ & $\begin{array}{c}0.069 \\
(0.051)\end{array}$ & $\begin{array}{c}0.088 \\
(0.056)\end{array}$ \\
\hline Founder of non-German origin $(=1)$ & $\begin{array}{l}-0.101 \\
(0.395)\end{array}$ & $\begin{array}{c}0.252 \\
(0.554)\end{array}$ & $\begin{array}{c}-0.032 \\
(0.063)\end{array}$ & $\begin{array}{c}-1.922^{* * *} \\
(0.708)\end{array}$ & $\begin{array}{c}-0.828 \\
(0.508)\end{array}$ & $\begin{array}{l}-0.079^{*} \\
(0.046)\end{array}$ & $\begin{array}{l}-0.085^{*} \\
(0.048)\end{array}$ \\
\hline SE Subsidy by Federal Employment Agency (=1) & $\begin{array}{c}0.333 \\
(0.234)\end{array}$ & $\begin{array}{l}-0.389 \\
(0.341)\end{array}$ & $\begin{array}{c}0.071^{* *} \\
(0.036)\end{array}$ & $\begin{array}{c}-0.633^{* *} \\
(0.307)\end{array}$ & $\begin{array}{c}-0.236 \\
(0.198)\end{array}$ & $\begin{array}{l}-0.049 \\
(0.035)\end{array}$ & $\begin{array}{c}-0.058 \\
(0.040)\end{array}$ \\
\hline IV_06 & $\begin{array}{c}\mathbf{- 8 . 4 0 1}^{* * *} \\
(0.569) \\
\end{array}$ & & & & & & \\
\hline Industry/Year Fixed Effects & Yes & Yes & Yes & Yes & Yes & Yes & Yes \\
\hline $\begin{array}{l}\text { First-stage F-statistic } \\
\mathrm{N} \\
\text { R-sq. }\end{array}$ & $\begin{array}{l}1022 \\
0.477\end{array}$ & $\begin{array}{c}217.975 \\
1022 \\
0.232 \\
\end{array}$ & $\begin{array}{c}209.815 \\
999 \\
0.083 \\
\end{array}$ & $\begin{array}{c}155.049 \\
815 \\
0.079\end{array}$ & $\begin{array}{c}153.108 \\
661 \\
0.110 \\
\end{array}$ & $\begin{array}{c}217.975 \\
1022 \\
0.153\end{array}$ & $\begin{array}{c}216.04 \\
1009 \\
0.145\end{array}$ \\
\hline $\begin{array}{l}\text { Mean of dependent variable } \\
\text { (abs. value for log-terms) }\end{array}$ & 12.327 & 4.895 & 0.352 & $\begin{array}{c}10.21 \\
179,344\end{array}$ & $\begin{array}{c}11.251 \\
237,112\end{array}$ & $\begin{array}{c}0.25 \\
0.549\end{array}$ & $\begin{array}{c}0.329 \\
0.76\end{array}$ \\
\hline
\end{tabular}

Notes: Standard errors are shown in parentheses and significance levels are indicated by: $* * * 1 \%, * * 5 \%, * 10 \%$. This table shows the IV regression of our outcome variables (AUD, motivation for starting up; sales/employment growth after year 1,2) on the founders' PBD before starting up in the non-manufacturing sector (75\% of the sample) that is instrumented by IV06 (Section 3.2). Column 1 shows the first-stage regression of the IV model in column 2. We control for the founders' education, previous work experience, and individual characteristics. We include year and industry (of the startup, see Table 3) fixed effects, and dummies to control for the receipt of self-employment (SE) related subsidies from the Federal Employment Agency and for funding by the KfW (Appendix C.2). Our regression sample consists of non-team founders who became unemployed between 2003 and 2011, were 35 to 65 years old when becoming unemployed, and for whom information on all control variables is available. 
Table 12: IV Results for Reform 2006: Actual Unemployment Duration (AUD) on Motivation of Founder and Firm Outcomes

\begin{tabular}{|c|c|c|c|c|c|c|}
\hline & $\begin{array}{c}(1) \\
\text { AUD } \\
\text { (in months) }\end{array}$ & $\begin{array}{c}(2) \\
\text { Necessity Motive } \\
(=1)\end{array}$ & $\begin{array}{c}(3) \\
\text { Sales Year } 1 \\
(\log )\end{array}$ & $\begin{array}{c}(4) \\
\text { Sales Year } 2 \\
(\log )\end{array}$ & $\begin{array}{c}(5) \\
\text { FTE Employment } \\
\text { Year } 1(\log )\end{array}$ & $\begin{array}{c}(6) \\
\text { FTE Employment } \\
\text { Year } 2(\log )\end{array}$ \\
\hline Actual unemployment duration (AUD) (in months) & & $\begin{array}{l}\mathbf{0 . 0 2 2}^{* *} \\
(0.010)\end{array}$ & $\begin{array}{c}\mathbf{0 . 0 6 0} \\
(0.095)\end{array}$ & $\begin{array}{c}-\mathbf{- 0 . 1 1 8}^{*} \\
(0.063)\end{array}$ & $\begin{array}{c}\mathbf{0 . 0 0 5} \\
(0.011)\end{array}$ & $\begin{array}{c}\mathbf{- 0 . 0 1 0} \\
(0.012)\end{array}$ \\
\hline Tertiary degree $(=1)$ & $\begin{array}{l}-0.313 \\
(0.311)\end{array}$ & $\begin{array}{c}-0.063^{* *} \\
(0.031)\end{array}$ & $\begin{array}{c}-0.662^{* *} \\
(0.287)\end{array}$ & $\begin{array}{l}-0.030 \\
(0.164)\end{array}$ & $\begin{array}{l}0.074^{* *} \\
(0.034)\end{array}$ & $\begin{array}{c}0.073^{*} \\
(0.039)\end{array}$ \\
\hline Founder was self-employed before $(=1)$ & $\begin{array}{c}0.067 \\
(0.357)\end{array}$ & $\begin{array}{l}-0.024 \\
(0.037)\end{array}$ & $\begin{array}{l}-0.023 \\
(0.343)\end{array}$ & $\begin{array}{l}-0.129 \\
(0.208)\end{array}$ & $\begin{array}{l}-0.013 \\
(0.040)\end{array}$ & $\begin{array}{l}-0.020 \\
(0.045)\end{array}$ \\
\hline Managerial experience as employee $(=1)$ & $\begin{array}{c}0.144 \\
(0.380)\end{array}$ & $\begin{array}{c}-0.076^{* *} \\
(0.038)\end{array}$ & $\begin{array}{c}0.146 \\
(0.358)\end{array}$ & $\begin{array}{c}0.624^{* * *} \\
(0.162)\end{array}$ & $\begin{array}{c}0.130^{* * *} \\
(0.050)\end{array}$ & $\begin{array}{c}0.171^{* * *} \\
(0.057)\end{array}$ \\
\hline Industry experience (in years) & $\begin{array}{c}-0.008 \\
(0.015)\end{array}$ & $\begin{array}{c}0.001 \\
(0.001)\end{array}$ & $\begin{array}{l}0.035^{* *} \\
(0.015)\end{array}$ & $\begin{array}{c}0.003 \\
(0.010)\end{array}$ & $\begin{array}{c}0.001 \\
(0.002)\end{array}$ & $\begin{array}{c}0.001 \\
(0.002)\end{array}$ \\
\hline Female founder $(=1)$ & $\begin{array}{c}0.240 \\
(0.361)\end{array}$ & $\begin{array}{l}-0.001 \\
(0.038)\end{array}$ & $\begin{array}{c}-1.118^{* * *} \\
(0.408)\end{array}$ & $\begin{array}{l}-0.357^{*} \\
(0.205)\end{array}$ & $\begin{array}{c}0.062 \\
(0.047)\end{array}$ & $\begin{array}{l}0.101^{*} \\
(0.052)\end{array}$ \\
\hline Founder of non-German origin $(=1)$ & $\begin{array}{c}0.226 \\
(0.505)\end{array}$ & $\begin{array}{c}0.037 \\
(0.059)\end{array}$ & $\begin{array}{c}-1.928^{* * *} \\
(0.670)\end{array}$ & $\begin{array}{l}-0.489 \\
(0.400)\end{array}$ & $\begin{array}{l}-0.024 \\
(0.055)\end{array}$ & $\begin{array}{c}-0.054 \\
(0.054)\end{array}$ \\
\hline SE Subsidy by Federal Employment Agency (=1) & $\begin{array}{l}-0.086 \\
(0.311)\end{array}$ & $\begin{array}{l}0.075^{* *} \\
(0.031)\end{array}$ & $\begin{array}{l}-0.423 \\
(0.281)\end{array}$ & $\begin{array}{l}-0.288^{*} \\
(0.166)\end{array}$ & $\begin{array}{l}-0.054 \\
(0.034)\end{array}$ & $\begin{array}{c}-0.085^{* *} \\
(0.037)\end{array}$ \\
\hline IV_06 & $\begin{array}{c}\mathbf{- 5 . 8 1 5} \\
(0.921)\end{array}$ & & & & & \\
\hline Industry/Year Fixed Effects & Yes & Yes & Yes & Yes & Yes & Yes \\
\hline $\begin{array}{l}\text { First-stage F-statistic } \\
\mathrm{N} \\
\text { R-sq. }\end{array}$ & $\begin{array}{l}1256 \\
0.189 \\
\end{array}$ & $\begin{array}{c}39.831 \\
1256 \\
0.075 \\
\end{array}$ & $\begin{array}{c}23.487 \\
1039 \\
0.072 \\
\end{array}$ & $\begin{array}{c}24.016 \\
851 \\
0.124 \\
\end{array}$ & $\begin{array}{c}40.992 \\
1291 \\
0.120 \\
\end{array}$ & $\begin{array}{l}41.07 \\
1272 \\
0.149 \\
\end{array}$ \\
\hline $\begin{array}{l}\text { Mean of dependent variable } \\
\text { (abs. value for log-terms) }\end{array}$ & 4.828 & 0.35 & $\begin{array}{c}10.074 \\
173,661\end{array}$ & $\begin{array}{c}11.271 \\
231,293\end{array}$ & $\begin{array}{l}0.271 \\
0.605\end{array}$ & $\begin{array}{l}0.361 \\
0.847\end{array}$ \\
\hline
\end{tabular}

Notes: Standard errors are shown in parentheses and significance levels are indicated by: *** 1\%,** 5\%,*10\%. This table shows the IV regression of our outcome variables (motivation for starting up; sales/employment growth after year 1,2) on the founders' actual unemployment duration (AUD) before starting up that is instrumented by IVO6 (Section 3.2). Column 1 shows the first-stage regression of the IV model in column 2. We control for the founders' education, previous work experience, and individual characteristics. We include year and industry (of the startup, see Table 3) fixed effects, and dummies to control for the receipt of self-employment (SE) related subsidies from the Federal Employment Agency and for funding by the KfW (Appendix C.2). Our regression sample consists of non-team founders who became unemployed between 2003 and 2011, were 35 to 65 years old when becoming unemployed, and for whom information on all control variables is available. 
Table 13: IV Results for Reform 2006: Actual Unemployment Duration (AUD) on Motivation of Founder and Firm Outcomes for Non-Manufacturing Sector

\begin{tabular}{|c|c|c|c|c|c|c|}
\hline & $\begin{array}{c}\text { (1) } \\
\text { AUD } \\
\text { (in months) }\end{array}$ & $\begin{array}{c}(2) \\
\text { Necessity Motive } \\
(=1)\end{array}$ & $\begin{array}{l}(3) \\
\text { Sales Year } 1 \\
(\log )\end{array}$ & $\begin{array}{l}(4) \\
\text { Sales Year } 2(\log ) \\
(\log )\end{array}$ & $\begin{array}{c}(5) \\
\text { FTE Employment } \\
\text { Year } 1(\log )\end{array}$ & $\begin{array}{c}(6) \\
\text { FTE Employment } \\
\text { Year } 2(\log )\end{array}$ \\
\hline Actual unemployment duration (AUD) (in months) & & $\begin{array}{c}\mathbf{0 . 0 1 4} \\
(0.011)\end{array}$ & $\begin{array}{c}\mathbf{0 . 0 0 7} \\
(0.092)\end{array}$ & $\begin{array}{c}\mathbf{- 0 . 1 7 1} \text { ** } \\
(0.077)\end{array}$ & $\begin{array}{c}-\mathbf{- 0 . 0 1 1} \\
(0.009)\end{array}$ & $\begin{array}{c}\mathbf{- 0 . 0 2 5} \text { ** } \\
(0.011)\end{array}$ \\
\hline Tertiary degree $(=1)$ & $\begin{array}{l}-0.305 \\
(0.357)\end{array}$ & $\begin{array}{c}-0.081^{* *} \\
(0.035)\end{array}$ & $\begin{array}{l}-0.387 \\
(0.289)\end{array}$ & $\begin{array}{c}0.145 \\
(0.163)\end{array}$ & $\begin{array}{c}0.057 \\
(0.035)\end{array}$ & $\begin{array}{c}0.056 \\
(0.040)\end{array}$ \\
\hline Founder was self-employed before $(=1)$ & $\begin{array}{c}0.243 \\
(0.374)\end{array}$ & $\begin{array}{l}-0.001 \\
(0.042)\end{array}$ & $\begin{array}{c}0.074 \\
(0.346)\end{array}$ & $\begin{array}{l}-0.283 \\
(0.228)\end{array}$ & $\begin{array}{c}0.011 \\
(0.044)\end{array}$ & $\begin{array}{c}0.030 \\
(0.050)\end{array}$ \\
\hline Managerial experience as employee $(=1)$ & $\begin{array}{l}0.158 \\
(0.434)\end{array}$ & $\begin{array}{l}-0.105^{* *} \\
(0.042)\end{array}$ & $\begin{array}{l}-0.001 \\
(0.380)\end{array}$ & $\begin{array}{c}0.475^{* * *} \\
(0.183)\end{array}$ & $\begin{array}{l}0.128^{* *} \\
(0.053)\end{array}$ & $\begin{array}{c}0.177^{* * *} \\
(0.060)\end{array}$ \\
\hline Industry experience (in years) & $\begin{array}{c}0.002 \\
(0.017)\end{array}$ & $\begin{array}{c}0.001 \\
(0.002)\end{array}$ & $\begin{array}{c}0.019 \\
(0.016)\end{array}$ & $\begin{array}{c}0.002 \\
(0.012)\end{array}$ & $\begin{array}{c}0.001 \\
(0.002)\end{array}$ & $\begin{array}{c}0.002 \\
(0.002)\end{array}$ \\
\hline Female founder $(=1)$ & $\begin{array}{l}0.356 \\
(0.407)\end{array}$ & $\begin{array}{l}-0.003 \\
(0.042)\end{array}$ & $\begin{array}{c}-0.823^{* *} \\
(0.419)\end{array}$ & $\begin{array}{l}-0.485^{* *} \\
(0.227)\end{array}$ & $\begin{array}{c}0.072 \\
(0.051)\end{array}$ & $\begin{array}{l}0.095^{*} \\
(0.055)\end{array}$ \\
\hline Founder of non-German origin $(=1)$ & $\begin{array}{c}0.198 \\
(0.551)\end{array}$ & $\begin{array}{l}-0.035 \\
(0.063)\end{array}$ & $\begin{array}{c}-1.925^{* * *} \\
(0.709)\end{array}$ & $\begin{array}{l}-0.781^{*} \\
(0.464)\end{array}$ & $\begin{array}{l}-0.076^{*} \\
(0.046)\end{array}$ & $\begin{array}{l}-0.078^{*} \\
(0.047)\end{array}$ \\
\hline SE Subsidy by Federal Employment Agency $(=1)$ & $\begin{array}{l}-0.084 \\
(0.367)\end{array}$ & $\begin{array}{l}0.075^{* *} \\
(0.035)\end{array}$ & $\begin{array}{c}-0.631^{* *} \\
(0.306)\end{array}$ & $\begin{array}{l}-0.280 \\
(0.201)\end{array}$ & $\begin{array}{l}-0.053 \\
(0.035)\end{array}$ & $\begin{array}{l}-0.068^{*} \\
(0.039)\end{array}$ \\
\hline IV_06 & 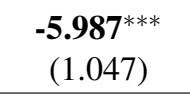 & & & & & \\
\hline Industry/Year Fixed Effects & Yes & Yes & Yes & Yes & Yes & Yes \\
\hline $\begin{array}{l}\text { First-stage F-statistic } \\
\mathrm{N} \\
\text { R-sq. }\end{array}$ & $\begin{array}{c}999 \\
0.209\end{array}$ & $\begin{array}{c}32.673 \\
999 \\
0.089\end{array}$ & $\begin{array}{c}19.62 \\
815 \\
0.077\end{array}$ & $\begin{array}{c}19.994 \\
661 \\
0.124 \\
\end{array}$ & $\begin{array}{c}34.939 \\
1022 \\
0.165 \\
\end{array}$ & $\begin{array}{c}34.852 \\
1009 \\
0.168\end{array}$ \\
\hline $\begin{array}{l}\text { Mean of dependent variable } \\
\text { (abs. value for log-terms) }\end{array}$ & 4.926 & 0.352 & $\begin{array}{c}10.21 \\
179,344\end{array}$ & $\begin{array}{c}11.251 \\
237,112\end{array}$ & $\begin{array}{c}0.25 \\
0.549\end{array}$ & $\begin{array}{c}0.329 \\
0.76\end{array}$ \\
\hline
\end{tabular}

Notes: Standard errors are shown in parentheses and significance levels are indicated by: *** 1\%,** 5\%,*10\%. This table shows the IV regression of our outcome variables (motivation for starting up; sales/employment growth after year 1,2) on the founders' actual unemployment duration (AUD) before starting up in the non-manufacturing sector (75\% of the sample) that is instrumented by IVO6 (Section 3.2). Column 1 shows the first-stage regression of the IV model in column 2. We control for the founders' education, previous work experience, and individual characteristics. We include year and industry (of the startup, see Table 3) fixed effects, and dummies to control for the receipt of self-employment (SE) related subsidies from the Federal Employment Agency and for funding by the KfW (Appendix C.2). Our regression sample consists of non-team founders who became unemployed between 2003 and 2011, were 35 to 65 years old when becoming unemployed, and for whom information on all control variables is available. 
Table 14: Composition or Individual-Level Duration Effects as Mechanism: Analyzing (Observable) Composition Changes

\begin{tabular}{|c|c|c|c|c|c|c|c|c|c|c|c|c|}
\hline & \multicolumn{3}{|c|}{$\begin{array}{l}\text { Treated unemployed } \\
\text { from main sample }\end{array}$} & \multicolumn{3}{|c|}{$\begin{array}{l}\text { All unemployed } \\
\text { from main sample }\end{array}$} & \multicolumn{3}{|c|}{$\begin{array}{l}\text { "Treated" non-unemployed } \\
\text { from comparison group }\end{array}$} & \multicolumn{3}{|c|}{$\begin{array}{l}\text { All non-unemployed } \\
\text { from comparison group }\end{array}$} \\
\hline & $\begin{array}{l}\text { Mean } \\
\text { (before) } \\
\mathrm{N}=106\end{array}$ & $\begin{array}{l}\text { Mean } \\
\text { (after) } \\
\mathrm{N}=397\end{array}$ & $\begin{array}{l}\text { After } \\
\text {-before }\end{array}$ & $\begin{array}{l}\text { Mean } \\
\text { (before) } \\
\mathrm{N}=259\end{array}$ & $\begin{array}{l}\text { Mean } \\
\text { (after) } \\
\mathrm{N}=1032\end{array}$ & $\begin{array}{l}\text { After } \\
\text {-before }\end{array}$ & $\begin{array}{l}\text { Mean } \\
\text { (before) } \\
\mathrm{N}=94\end{array}$ & $\begin{array}{l}\text { Mean } \\
\text { (after) } \\
\mathrm{N}=509\end{array}$ & $\begin{array}{l}\text { After } \\
\text {-before }\end{array}$ & $\begin{array}{l}\text { Mean } \\
\text { (before) } \\
\mathrm{N}=256\end{array}$ & $\begin{array}{l}\text { Mean } \\
\text { (after) } \\
\mathrm{N}=1354\end{array}$ & $\begin{array}{l}\text { After } \\
\text {-before }\end{array}$ \\
\hline Actual unemployment duration (AUD) (in months) & 11.171 & 4.873 & $-6.299 * * *$ & 7.943 & 4.193 & $-3.75 * * *$ & & & & & & \\
\hline Tertiary degree $(=1)$ & 0.33 & 0.28 & -0.05 & 0.20 & 0.23 & 0.03 & 0.32 & 0.30 & -0.03 & 0.35 & 0.25 & $-0.10^{*}$ \\
\hline Founder was self-employed before $(=1)$ & 0.17 & 0.19 & 0.02 & 0.15 & 0.18 & 0.03 & 0.26 & 0.32 & 0.05 & 0.25 & 0.27 & 0.01 \\
\hline Managerial experience as employee $(=1)$ & 0.17 & 0.15 & -0.02 & 0.13 & 0.13 & 0.00 & 0.16 & 0.19 & 0.03 & 0.14 & 0.16 & 0.02 \\
\hline Industry experience (in years) & 20.02 & 18.81 & -1.22 & 16.10 & 16.31 & 0.21 & 22.71 & 17.27 & $-5.44 * * *$ & 17.15 & 15.38 & -1.77 \\
\hline Female founder $(=1)$ & 0.17 & 0.25 & 0.08 & 0.13 & 0.20 & 0.07 & 0.18 & 0.23 & 0.05 & 0.14 & 0.20 & 0.06 \\
\hline Founder of non-German origin $(=1)$ & 0.08 & 0.04 & -0.03 & 0.04 & 0.07 & 0.03 & 0.08 & 0.05 & -0.02 & 0.06 & 0.07 & 0.01 \\
\hline SE Subsidy by Federal Employment Agency $(=1)$ & 0.65 & 0.80 & $0.15^{*}$ & 0.65 & 0.80 & $0.15 * * *$ & 0.27 & 0.34 & 0.07 & 0.30 & 0.36 & 0.06 \\
\hline Technology-intensive services & 0.05 & 0.06 & 0.01 & 0.05 & 0.05 & 0.00 & 0.05 & 0.06 & 0.01 & 0.06 & 0.06 & 0.00 \\
\hline High-technology manufacturing & 0.01 & 0.01 & 0.00 & 0.00 & 0.01 & $0.01 * * *$ & 0.01 & 0.02 & 0.01 & 0.01 & 0.01 & 0.00 \\
\hline Skill-intensive services & 0.06 & 0.08 & 0.02 & 0.03 & 0.05 & 0.02 & 0.08 & 0.08 & 0.00 & 0.09 & 0.07 & -0.02 \\
\hline Software supply and consultancy & 0.00 & 0.01 & 0.00 & 0.00 & 0.01 & $0.00 *$ & 0.01 & 0.01 & 0.00 & 0.01 & 0.01 & 0.00 \\
\hline Non-high-tech manufacturing & 0.03 & 0.04 & 0.01 & 0.04 & 0.05 & 0.01 & 0.03 & 0.05 & 0.02 & 0.03 & 0.05 & $0.02 * * *$ \\
\hline Other business-oriented services & 0.07 & 0.11 & 0.04 & 0.10 & 0.14 & 0.03 & 0.04 & 0.12 & $0.08^{*}$ & 0.12 & 0.12 & -0.01 \\
\hline Cons.-or. services in creative sect. & 0.08 & 0.02 & -0.06 & 0.10 & 0.05 & -0.05 & 0.24 & 0.11 & -0.13 & 0.15 & 0.09 & -0.06 \\
\hline Consumer-oriented services & 0.30 & 0.31 & 0.01 & 0.26 & 0.26 & 0.00 & 0.15 & 0.24 & 0.09 & 0.14 & 0.23 & $0.10^{*}$ \\
\hline Construction & 0.11 & 0.20 & $0.09^{*}$ & 0.19 & 0.20 & 0.01 & 0.12 & 0.10 & -0.02 & 0.16 & 0.14 & -0.02 \\
\hline Retail \& wholesale & 0.29 & 0.17 & -0.12 & 0.21 & 0.18 & -0.03 & 0.28 & 0.21 & -0.07 & 0.24 & 0.22 & -0.02 \\
\hline Average daily wage in 5 years before founding & 107.87 & 124.75 & 16.88 & 96.87 & 106.56 & 9.69 & 129.17 & 125.10 & -4.06 & 127.03 & 119.66 & -7.37 \\
\hline
\end{tabular}

Notes: Significance levels are indicated by: $* * * 1 \%, * * 5 \%, * 10 \%$. This table show t-test comparison of different subgroups for the observable characteristics. In the first panel, we compare those unemployed individuals that are affected by 2006 reform. In the second panel, we compare all unemployed individuals before and after the 2006 reform. In the third panel, we compare the potentially treated non-unemployed and in the fourth panel, we do so for all non-unemployed individuals. Results suggest that composition and individual-level duration effects play a role in explaining the overall effects but that the size of (observable) compositions effects is limited.) 


\section{A Appendix: Tables \& Figures}

\section{A.1 Figures}

Figure A.1: Spikes at exhausting Potential Benefit Duration: Necessity/Pushed Founders

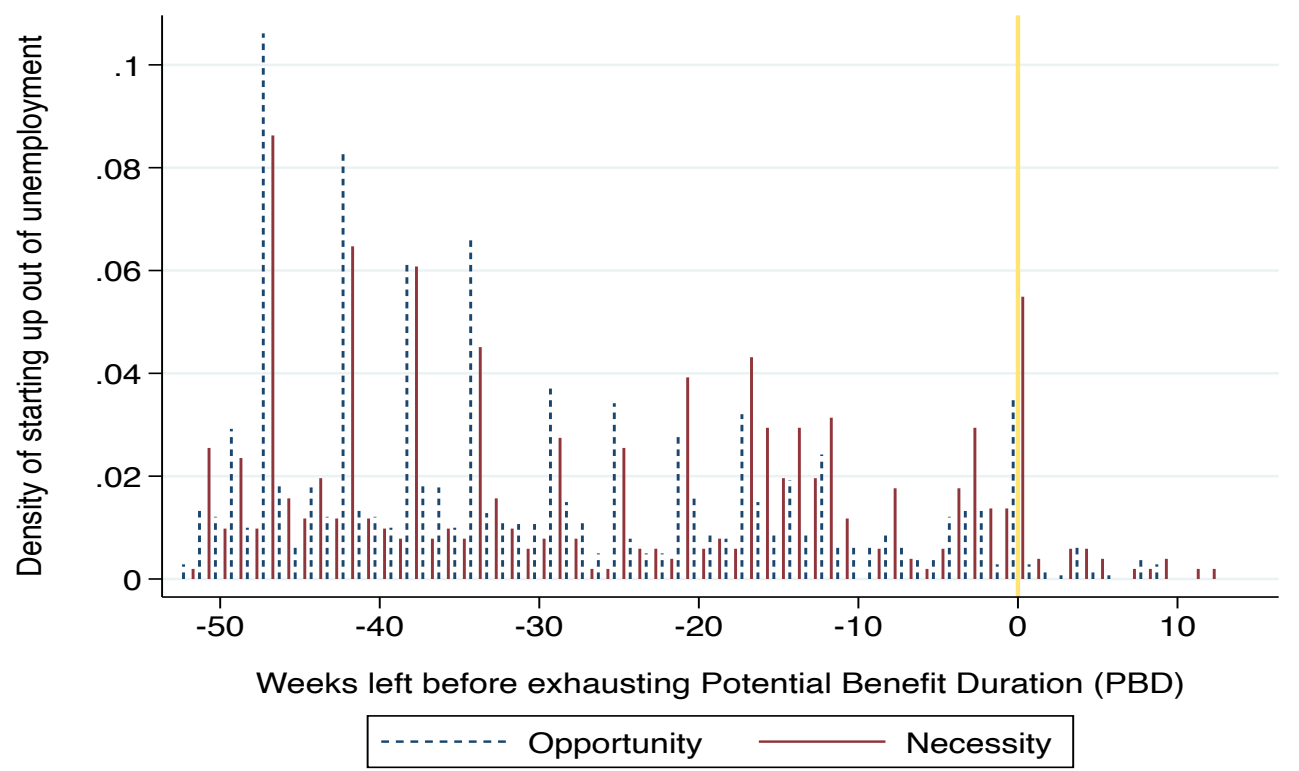

Notes: This Figure shows the difference between actual and potential unemployment duration, i.e. when the unemployed individual starts a firm given his/her remaining PBD. The Figure shows that when UI benefits run out (remaining PBD is close to 0) the spike in the exit rate from unemployment to self-employment is significantly higher for those indicating to start a firm due to necessity motives (red lines) compared to those indicating an opportunity motive (blue dashed spikes). Thus, it is plausible to use the term pushed for necessity-driven founders (cf. Section 2). For a review of the literature on UI spikes, see also Card et al. (2007).

Figure A.2: RDD-Strategy McCrary Test for Age 50 Cutoff in 2008-2011

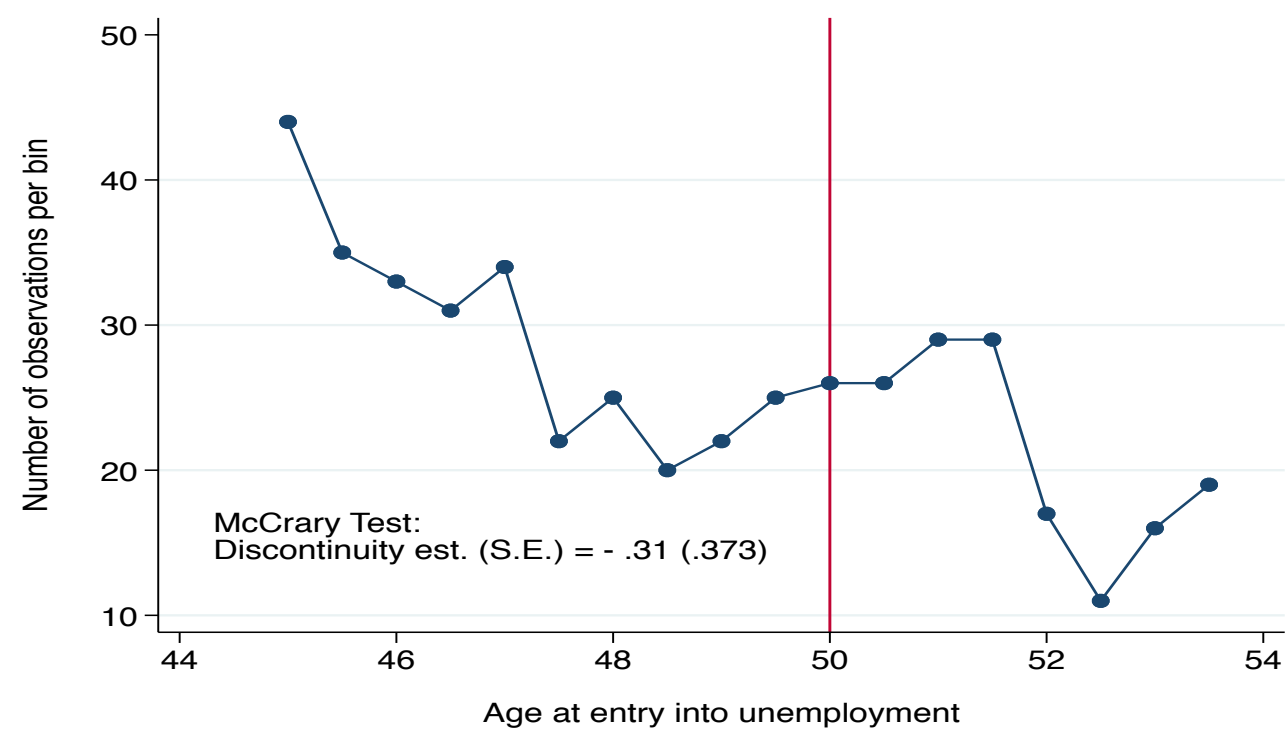

Notes: This Figure shows the necessary checks concerning the identifying assumption of the Regression Discontinuity Design (RDD) strategy. This involves conducting a McCrary test that confirms that eligible persons are not strategically becoming unemployed to exploit the age discontinuity in order to optimize their potential benefit duration (PBD). See also Section 4.2.1. 
Figure A.3: RDD-Results for Age 50 Cutoff in 2008-2011: Exogenous Increase of 3 months in PBD

(a) RDD-Results: Increase in Potential Benefit Duration (PBD)

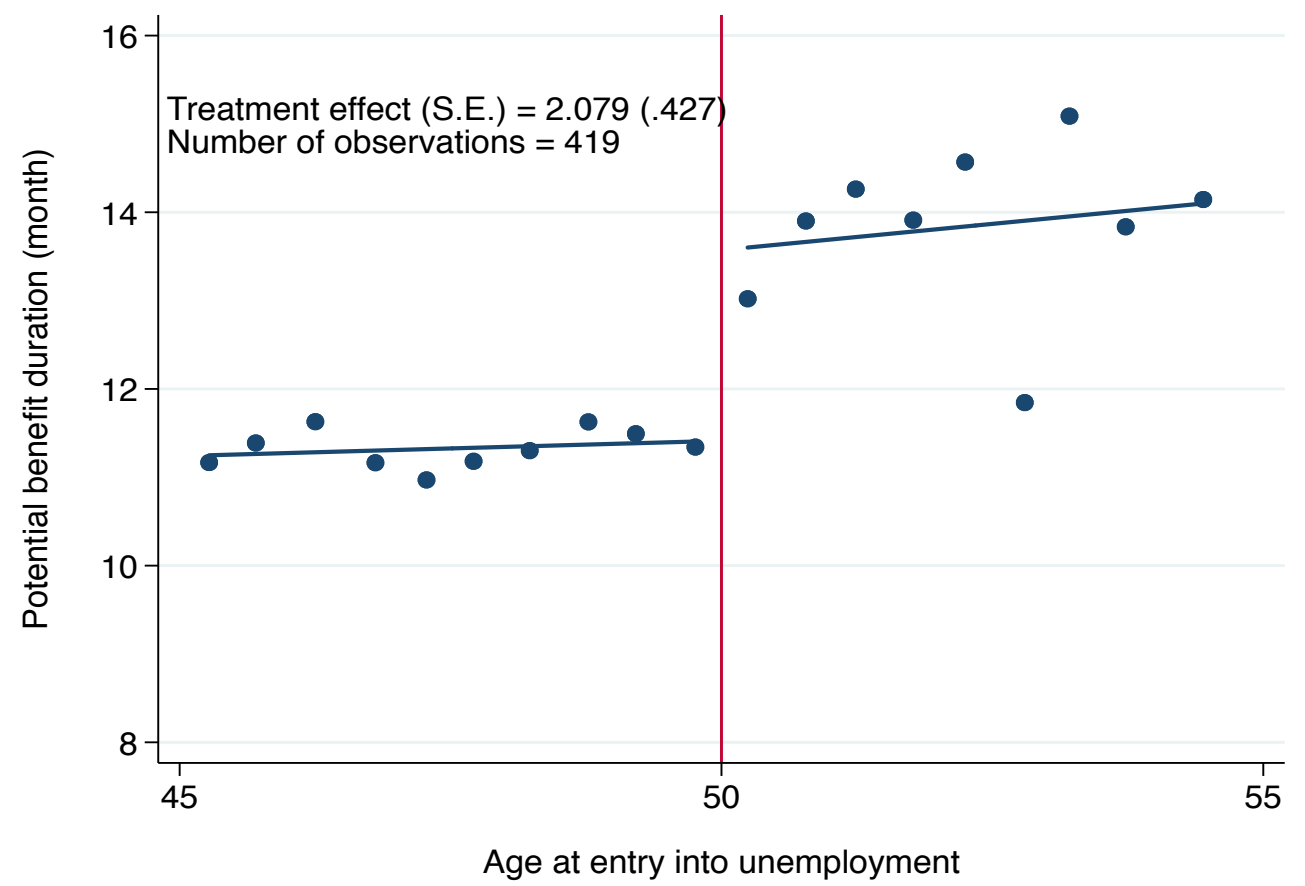

(b) RDD-Effect of 3 months Increase in PBD on Actual Unemployment Duration

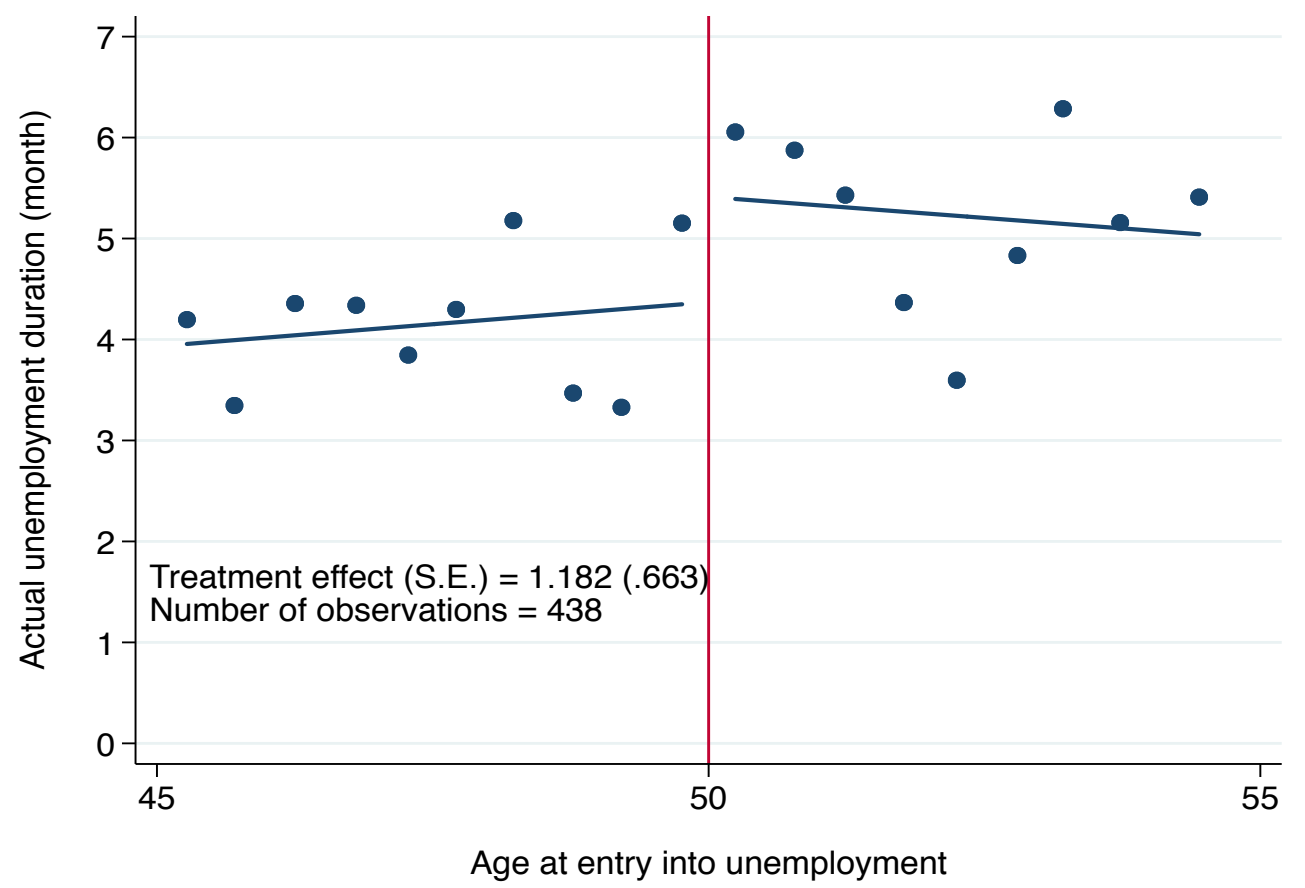

Notes: This Figure shows in (a) that potential benefit duration increases by approximately 3 months around the age 50 cutoff, thus it confirms that our data construction process has been successful. Moreover Figure (b) shows regression discontinuity design (RDD) results for the actual unemployment duration of non-team founders (age 45-54) who have become unemployed. Consistent with our IV estimates longer PBD increases actual unemployment duration (AUD). For details on the RDD strategy, see Section 4.2.1. 
Figure A.4: RDD-Results for Age 50 Cutoff in 2008-2011: Exogenous Increase of 3 months in PBD

(a) RDD-Results: Full-Time Equivalent (FTE) Employment after Year 1

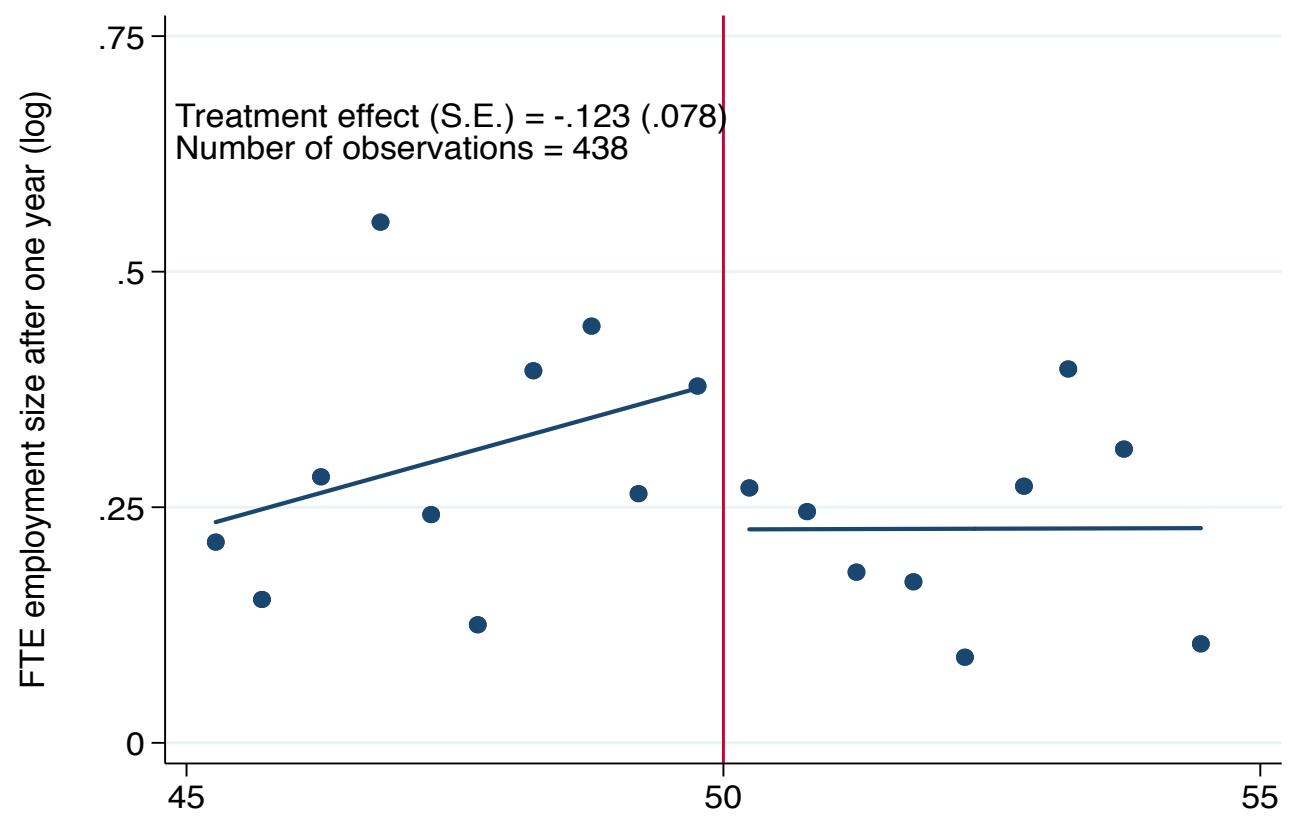

Age at entry into unemployment

(b) RDD-Results: Full-Time Equivalent (FTE) Employment after Year 2

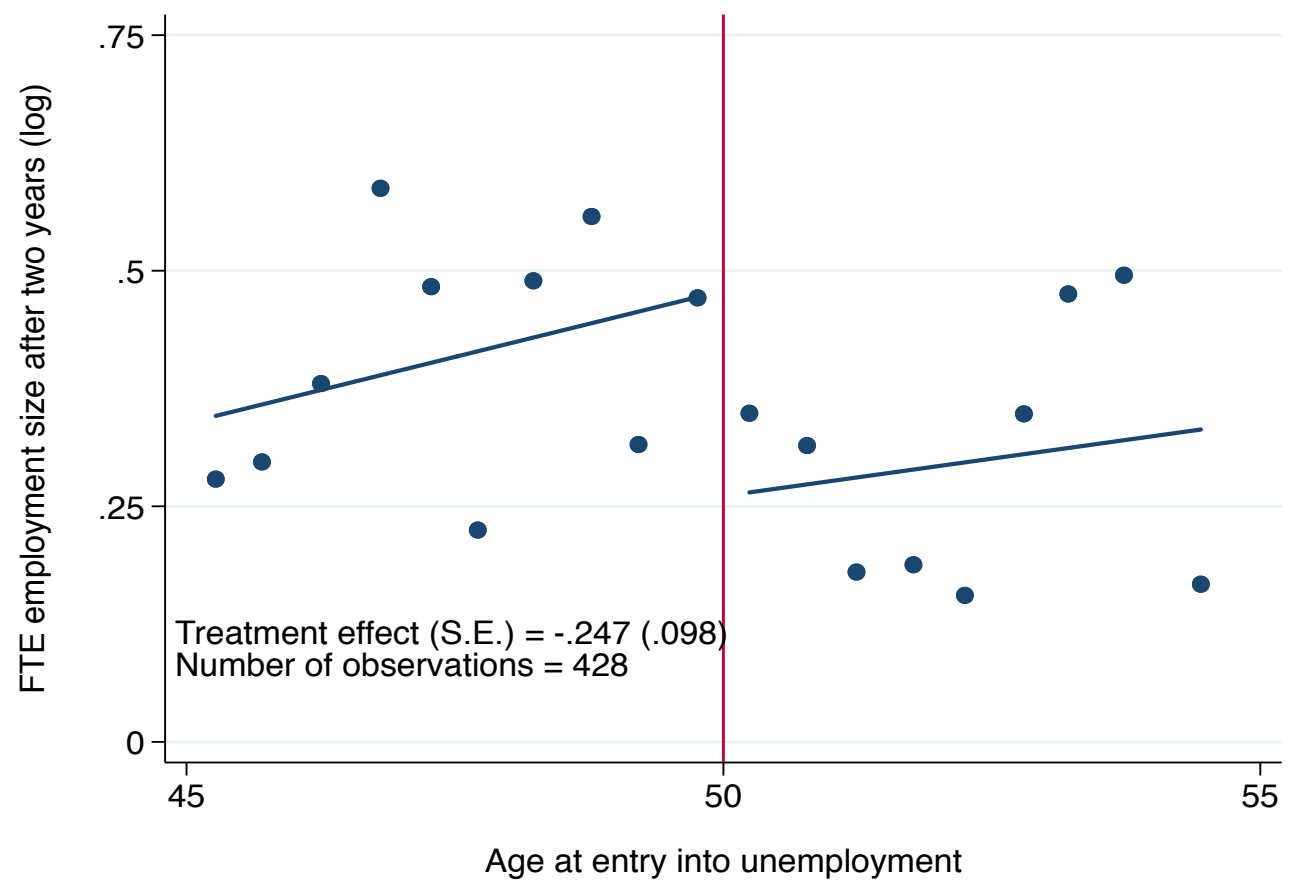

Notes: This Figure shows regression discontinuity design (RDD) results for employment growth outcomes of non-team founders (age 45-54) who have been previously unemployed. Consistent with our IV estimates longer actual unemployment duration induced by longer PBD leads to less growth in terms of FTE employment. For details on the RDD strategy, see Section 4.2.1. Detailed results are shown in Table A.5. 


\section{A.2 Tables}

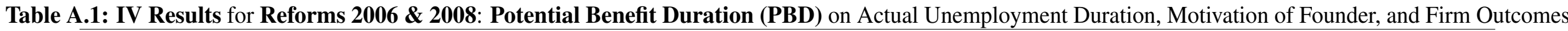

\begin{tabular}{|c|c|c|c|c|c|c|c|}
\hline & $\begin{array}{c}\text { (1) } \\
\text { PBD } \\
\text { (in months) }\end{array}$ & $\begin{array}{c}(2) \\
\text { AUD } \\
\text { (in months) }\end{array}$ & $\begin{array}{c}(3) \\
\text { Necessity Motive } \\
(=1)\end{array}$ & $\begin{array}{c}(4) \\
\text { Sales Year } 1 \\
(\log )\end{array}$ & $\begin{array}{c}(5) \\
\text { Sales Year } 2 \\
(\log )\end{array}$ & $\begin{array}{l}(6) \\
\text { FTE Employment } \\
\text { Year } 1(\log )\end{array}$ & $\begin{array}{l}\text { (7) } \\
\text { FTE Employment } \\
\text { Year } 2(\log )\end{array}$ \\
\hline Potential benefit duration (PBD) (in months) & & $\begin{array}{c}\mathbf{0 . 6 4 9} 9^{* * *} \\
(0.093)\end{array}$ & $\begin{array}{l}\mathbf{0 . 0 1 5}^{* *} \\
(0.007)\end{array}$ & $\begin{array}{c}\mathbf{0 . 0 3 0} \\
(0.049)\end{array}$ & $\begin{array}{c}\mathbf{- 0 . 0 7 4}^{* *} \\
(0.038)\end{array}$ & $\begin{array}{c}\mathbf{0 . 0 0 4} \\
(0.007)\end{array}$ & $\begin{array}{l}-\mathbf{- 0 . 0 0 6} \\
(0.008)\end{array}$ \\
\hline Tertiary degree $(=1)$ & $\begin{array}{c}0.247 \\
(0.217)\end{array}$ & $\begin{array}{l}-0.467 \\
(0.286)\end{array}$ & $\begin{array}{c}-0.076^{* *} \\
(0.032)\end{array}$ & $\begin{array}{c}-0.671^{* *} \\
(0.288)\end{array}$ & $\begin{array}{c}0.057 \\
(0.168)\end{array}$ & $\begin{array}{l}0.075^{* *} \\
(0.034)\end{array}$ & $\begin{array}{l}0.080^{* *} \\
(0.040)\end{array}$ \\
\hline Founder was self-employed before $(=1)$ & $\begin{array}{l}-0.157 \\
(0.268)\end{array}$ & $\begin{array}{c}0.185 \\
(0.342)\end{array}$ & $\begin{array}{l}-0.025 \\
(0.037)\end{array}$ & $\begin{array}{c}0.012 \\
(0.338)\end{array}$ & $\begin{array}{l}-0.082 \\
(0.207)\end{array}$ & $\begin{array}{l}-0.006 \\
(0.039)\end{array}$ & $\begin{array}{l}-0.018 \\
(0.045)\end{array}$ \\
\hline Managerial experience as employee $(=1)$ & $\begin{array}{c}0.291 \\
(0.302)\end{array}$ & $\begin{array}{l}-0.006 \\
(0.346)\end{array}$ & $\begin{array}{c}-0.077^{* *} \\
(0.038)\end{array}$ & $\begin{array}{c}0.150 \\
(0.353)\end{array}$ & $\begin{array}{c}0.615^{* * *} \\
(0.165)\end{array}$ & $\begin{array}{c}0.131^{* * *} \\
(0.050)\end{array}$ & $\begin{array}{c}0.172^{* * *} \\
(0.057)\end{array}$ \\
\hline Industry experience (in years) & $\begin{array}{c}0.008 \\
(0.011)\end{array}$ & $\begin{array}{l}-0.014 \\
(0.014)\end{array}$ & $\begin{array}{c}0.000 \\
(0.001)\end{array}$ & $\begin{array}{l}0.034^{* *} \\
(0.015)\end{array}$ & $\begin{array}{c}0.009 \\
(0.010)\end{array}$ & $\begin{array}{c}0.001 \\
(0.002)\end{array}$ & $\begin{array}{c}0.001 \\
(0.002)\end{array}$ \\
\hline Female founder $(=1)$ & $\begin{array}{l}-0.015 \\
(0.273)\end{array}$ & $\begin{array}{c}0.186 \\
(0.321)\end{array}$ & $\begin{array}{c}0.005 \\
(0.038)\end{array}$ & $\begin{array}{c}-1.100^{* * *} \\
(0.401)\end{array}$ & $\begin{array}{l}-0.368^{*} \\
(0.216)\end{array}$ & $\begin{array}{c}0.062 \\
(0.047)\end{array}$ & $\begin{array}{l}0.099^{*} \\
(0.052)\end{array}$ \\
\hline Founder of non-German origin $(=1)$ & $\begin{array}{c}0.134 \\
(0.364)\end{array}$ & $\begin{array}{c}0.219 \\
(0.504)\end{array}$ & $\begin{array}{c}0.042 \\
(0.058)\end{array}$ & $\begin{array}{c}-1.899^{* * *} \\
(0.666)\end{array}$ & $\begin{array}{l}-0.535 \\
(0.427)\end{array}$ & $\begin{array}{l}-0.022 \\
(0.054)\end{array}$ & $\begin{array}{l}-0.057 \\
(0.056)\end{array}$ \\
\hline SE Subsidy by Federal Employment Agency $(=1)$ & $\begin{array}{l}0.446^{* *} \\
(0.210)\end{array}$ & $\begin{array}{l}-0.411 \\
(0.295)\end{array}$ & $\begin{array}{l}0.067^{* *} \\
(0.031)\end{array}$ & $\begin{array}{l}-0.446 \\
(0.280)\end{array}$ & $\begin{array}{l}-0.272 \\
(0.167)\end{array}$ & $\begin{array}{l}-0.058^{*} \\
(0.033)\end{array}$ & $\begin{array}{c}-0.081^{* *} \\
(0.038)\end{array}$ \\
\hline $\begin{array}{l}\text { IV_06 } \\
\text { IV_08 }\end{array}$ & $\begin{array}{c}\mathbf{- 9 . 3 1 6}^{* * *} \\
(0.514) \\
\mathbf{2 . 3 5 6}^{* * *} \\
(0.353) \\
\end{array}$ & & & & & & \\
\hline Industry/Year Fixed Effects & Yes & Yes & Yes & Yes & Yes & Yes & Yes \\
\hline $\begin{array}{l}\text { First-stage F-statistic } \\
\mathrm{N} \\
\mathrm{R} \text {-sq. }\end{array}$ & $\begin{array}{l}1291 \\
0.487 \\
\end{array}$ & $\begin{array}{l}41.07 \\
1291 \\
0.242 \\
\end{array}$ & $\begin{array}{c}147.61 \\
1256 \\
0.084 \\
\end{array}$ & $\begin{array}{c}115.608 \\
1039 \\
0.096 \\
\end{array}$ & $\begin{array}{c}119.869 \\
851 \\
0.094\end{array}$ & $\begin{array}{c}154.434 \\
1291 \\
0.133 \\
\end{array}$ & $\begin{array}{c}152.383 \\
1272 \\
0.135 \\
\end{array}$ \\
\hline $\begin{array}{l}\text { Mean of dependent variable } \\
\text { (abs. value for log-terms) }\end{array}$ & 12.324 & 4.785 & 0.35 & $\begin{array}{c}10.074 \\
173,661\end{array}$ & $\begin{array}{c}11.271 \\
231,293\end{array}$ & $\begin{array}{l}0.271 \\
0.605\end{array}$ & $\begin{array}{l}0.361 \\
0.847\end{array}$ \\
\hline
\end{tabular}

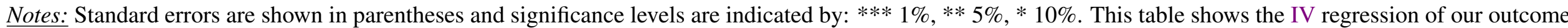

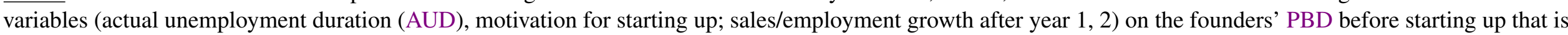

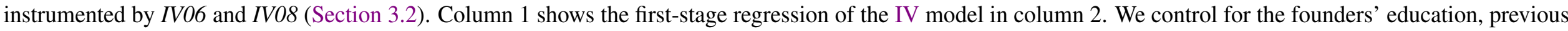

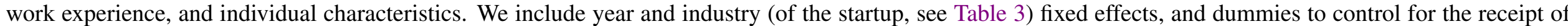

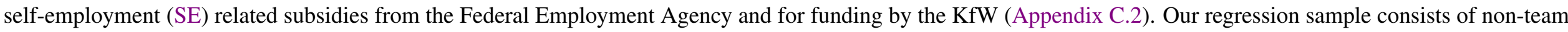
founders who became unemployed between 2003 and 2011, were 35 to 65 years old when becoming unemployed, and for whom all control variables are available. 
Table A.2: IV Results for Reforms 2006 \& 2008: PBD on Actual Unemployment Duration, Motiv. of Founder, Firm Outcomes for Non-Manufacturing Sector

\begin{tabular}{|c|c|c|c|c|c|c|c|}
\hline & $\begin{array}{c}(1) \\
\text { PBD } \\
\text { (in months) }\end{array}$ & $\begin{array}{c}(2) \\
\text { AUD } \\
\text { (in months) } \\
\end{array}$ & $\begin{array}{c}(3) \\
\text { Necessity Motive } \\
(=1)\end{array}$ & $\begin{array}{c}(4) \\
\text { Sales Year } 1 \\
(\log )\end{array}$ & $\begin{array}{c}(5) \\
\text { Sales Year } 2 \\
(\log )\end{array}$ & $\begin{array}{l}(6) \\
\text { FTE Employment } \\
\text { Year } 1(\log )\end{array}$ & $\begin{array}{l}(7) \\
\text { FTE Employment } \\
\text { Year } 2(\log )\end{array}$ \\
\hline Potential benefit duration (PBD) (in months) & & $\begin{array}{c}\mathbf{0 . 7 2 1}^{* * *} \\
(0.108)\end{array}$ & $\begin{array}{c}\mathbf{0 . 0 1 0} \\
(0.008)\end{array}$ & $\begin{array}{c}\mathbf{- 0 . 0 0 2} \\
(0.055)\end{array}$ & $\begin{array}{c}\mathbf{- 0 . 1 1 5}^{* *} \\
(0.050)\end{array}$ & $\begin{array}{c}\mathbf{- 0 . 0 0 7} \\
(0.007)\end{array}$ & $\begin{array}{c}\mathbf{- 0 . 0 1 7}^{* *} \\
(0.008)\end{array}$ \\
\hline Tertiary degree $(=1)$ & $\begin{array}{c}0.391 \\
(0.244)\end{array}$ & $\begin{array}{c}-0.585^{*} \\
(0.327)\end{array}$ & $\begin{array}{c}-0.091^{* *} \\
(0.036)\end{array}$ & $\begin{array}{c}-0.371 \\
(0.295)\end{array}$ & $\begin{array}{c}0.266 \\
(0.166)\end{array}$ & $\begin{array}{l}0.066^{*} \\
(0.036)\end{array}$ & $\begin{array}{l}0.072^{*} \\
(0.041)\end{array}$ \\
\hline Founder was self-employed before $(=1)$ & $\begin{array}{l}-0.396 \\
(0.304)\end{array}$ & $\begin{array}{c}0.595 \\
(0.380)\end{array}$ & $\begin{array}{c}0.003 \\
(0.042)\end{array}$ & $\begin{array}{c}0.097 \\
(0.352)\end{array}$ & $\begin{array}{l}-0.275 \\
(0.233)\end{array}$ & $\begin{array}{c}0.009 \\
(0.044)\end{array}$ & $\begin{array}{c}0.021 \\
(0.051)\end{array}$ \\
\hline Managerial experience as employee $(=1)$ & $\begin{array}{c}0.112 \\
(0.348)\end{array}$ & $\begin{array}{c}0.096 \\
(0.381)\end{array}$ & $\begin{array}{c}-0.106^{* *} \\
(0.043)\end{array}$ & $\begin{array}{c}0.006 \\
(0.378)\end{array}$ & $\begin{array}{l}0.422^{* *} \\
(0.185)\end{array}$ & $\begin{array}{l}0.128^{* *} \\
(0.053)\end{array}$ & $\begin{array}{c}0.177^{* * *} \\
(0.060)\end{array}$ \\
\hline Industry experience (in years) & $\begin{array}{c}0.006 \\
(0.012)\end{array}$ & $\begin{array}{l}-0.003 \\
(0.016)\end{array}$ & $\begin{array}{c}0.001 \\
(0.002)\end{array}$ & $\begin{array}{c}0.020 \\
(0.016)\end{array}$ & $\begin{array}{c}0.008 \\
(0.012)\end{array}$ & $\begin{array}{c}0.002 \\
(0.002)\end{array}$ & $\begin{array}{c}0.002 \\
(0.002)\end{array}$ \\
\hline Female founder $(=1)$ & $\begin{array}{c}0.065 \\
(0.312)\end{array}$ & $\begin{array}{c}0.298 \\
(0.362)\end{array}$ & $\begin{array}{c}0.002 \\
(0.042)\end{array}$ & $\begin{array}{c}-0.825^{* *} \\
(0.411)\end{array}$ & $\begin{array}{c}-0.533^{* *} \\
(0.238)\end{array}$ & $\begin{array}{c}0.068 \\
(0.051)\end{array}$ & $\begin{array}{c}0.088 \\
(0.056)\end{array}$ \\
\hline Founder of non-German origin $(=1)$ & $\begin{array}{c}0.031 \\
(0.386)\end{array}$ & $\begin{array}{c}0.214 \\
(0.558)\end{array}$ & $\begin{array}{l}-0.030 \\
(0.063)\end{array}$ & $\begin{array}{c}-1.928^{* * *} \\
(0.710)\end{array}$ & $\begin{array}{c}-0.824 \\
(0.510)\end{array}$ & $\begin{array}{l}-0.081^{*} \\
(0.046)\end{array}$ & $\begin{array}{l}-0.086^{*} \\
(0.048)\end{array}$ \\
\hline $\begin{array}{l}\text { IV_06 } \\
\text { IV_08 }\end{array}$ & $\begin{array}{c}\mathbf{- 8 . 9 5 5}^{* * *} \\
(0.579) \\
\mathbf{2 . 1 1 5}^{* * *} \\
(0.385) \\
\end{array}$ & & & & & & \\
\hline Industry/Year Fixed Effects & Yes & Yes & Yes & Yes & Yes & Yes & Yes \\
\hline $\begin{array}{l}\text { First-stage F-statistic } \\
\mathrm{N} \\
\mathrm{R} \text {-sq. }\end{array}$ & $\begin{array}{c}1022 \\
0.493 \\
\end{array}$ & $\begin{array}{c}34.852 \\
1022 \\
0.241 \\
\end{array}$ & $\begin{array}{c}107.841 \\
999 \\
0.084\end{array}$ & $\begin{array}{c}78.456 \\
815 \\
0.080 \\
\end{array}$ & $\begin{array}{c}84.474 \\
661 \\
0.110 \\
\end{array}$ & $\begin{array}{c}112.178 \\
1022 \\
0.155 \\
\end{array}$ & $\begin{array}{c}110.896 \\
1009 \\
0.146 \\
\end{array}$ \\
\hline $\begin{array}{l}\text { Mean of dependent variable } \\
\text { (abs. value for log-terms) }\end{array}$ & 12.327 & 4.895 & 0.352 & $\begin{array}{c}10.21 \\
179,344\end{array}$ & $\begin{array}{c}11.251 \\
237,112\end{array}$ & $\begin{array}{c}0.25 \\
0.549\end{array}$ & $\begin{array}{c}0.329 \\
0.76\end{array}$ \\
\hline
\end{tabular}

Notes: Standard errors are shown in parentheses and significance levels are indicated by: $* * * 1 \%, * * 5 \%, * 10 \%$. This table shows the IV regression of our outcome variables (AUD, motivation for starting up; sales/employment growth after year 1,2) on the founders' PBD before starting up in the non-manufacturing sector (75\% of the sample) that is instrumented by IVO6 and IVO8 (Section 3.2). Column 1 shows the first-stage regression of the IV model in column 2 . We control for the founders' education, previous work experience, and individual characteristics. We include year and industry (of the startup, see Table 3) fixed effects, and dummies to control for the receipt of self-employment (SE) related subsidies from the Federal Employment Agency and for funding by the KfW (Appendix C.2). Our regression sample consists of non-team founders who became unemployed between 2003 and 2011, were 35 to 65 years old when becoming unemployed, and for whom information on all control variables is available. 
Table A.3: IV Results for Reforms 2006 \& 2008: Actual Unemployment Duration (AUD) on Motivation of Founder and Firm Outcomes

\begin{tabular}{|c|c|c|c|c|c|c|}
\hline & $\begin{array}{c}(1) \\
\text { AUD } \\
\text { (in months) }\end{array}$ & $\begin{array}{c}(2) \\
\text { Necessity Motive } \\
(=1)\end{array}$ & $\begin{array}{c}(3) \\
\text { Sales Year } 1 \\
(\log )\end{array}$ & $\begin{array}{c}(4) \\
\text { Sales Year } 2 \\
(\log )\end{array}$ & $\begin{array}{l}\text { (5) } \\
\text { FTE Employment } \\
\text { Year } 1(\log )\end{array}$ & $\begin{array}{l}(6) \\
\text { FTE Employment } \\
\text { Year } 2(\log )\end{array}$ \\
\hline Actual unemployment duration (AUD) (in months) & & $\begin{array}{c}\mathbf{0 . 0 2 3}^{* *} \\
(0.010)\end{array}$ & $\begin{array}{c}\mathbf{0 . 0 5 8} \\
(0.095)\end{array}$ & $\begin{array}{l}\mathbf{- 0 . 1 2 1} * \\
(0.063)\end{array}$ & $\begin{array}{c}\mathbf{0 . 0 0 4} \\
(0.011)\end{array}$ & $\begin{array}{c}\mathbf{- 0 . 0 1 0} \\
(0.012)\end{array}$ \\
\hline Tertiary degree $(=1)$ & $\begin{array}{l}-0.314 \\
(0.311)\end{array}$ & $\begin{array}{c}-0.065^{* *} \\
(0.031)\end{array}$ & $\begin{array}{c}-0.649^{* *} \\
(0.287)\end{array}$ & $\begin{array}{l}-0.019 \\
(0.163)\end{array}$ & $\begin{array}{l}0.077^{* *} \\
(0.034)\end{array}$ & $\begin{array}{l}0.075^{*} \\
(0.039)\end{array}$ \\
\hline Founder was self-employed before $(=1)$ & $\begin{array}{c}0.065 \\
(0.358)\end{array}$ & $\begin{array}{l}-0.029 \\
(0.037)\end{array}$ & $\begin{array}{l}-0.002 \\
(0.342)\end{array}$ & $\begin{array}{l}-0.111 \\
(0.205)\end{array}$ & $\begin{array}{l}-0.007 \\
(0.040)\end{array}$ & $\begin{array}{l}-0.016 \\
(0.045)\end{array}$ \\
\hline Managerial experience as employee (=1) & $\begin{array}{c}0.143 \\
(0.381)\end{array}$ & $\begin{array}{c}-0.077^{* *} \\
(0.038)\end{array}$ & $\begin{array}{c}0.150 \\
(0.358)\end{array}$ & $\begin{array}{c}0.627^{* * *} \\
(0.161)\end{array}$ & $\begin{array}{c}0.131^{* * *} \\
(0.050)\end{array}$ & $\begin{array}{c}0.172^{* * *} \\
(0.056)\end{array}$ \\
\hline Industry experience (in years) & $\begin{array}{l}-0.008 \\
(0.015)\end{array}$ & $\begin{array}{c}0.001 \\
(0.001)\end{array}$ & $\begin{array}{l}0.036^{* *} \\
(0.015)\end{array}$ & $\begin{array}{c}0.004 \\
(0.010)\end{array}$ & $\begin{array}{c}0.001 \\
(0.002)\end{array}$ & $\begin{array}{c}0.001 \\
(0.002)\end{array}$ \\
\hline Female founder $(=1)$ & $\begin{array}{c}0.242 \\
(0.361)\end{array}$ & $\begin{array}{l}-0.001 \\
(0.038)\end{array}$ & $\begin{array}{c}-1.126^{* * *} \\
(0.407)\end{array}$ & $\begin{array}{l}-0.361^{*} \\
(0.204)\end{array}$ & $\begin{array}{c}0.061 \\
(0.047)\end{array}$ & $\begin{array}{l}0.100^{*} \\
(0.052)\end{array}$ \\
\hline Founder of non-German origin $(=1)$ & $\begin{array}{c}0.222 \\
(0.505)\end{array}$ & $\begin{array}{c}0.036 \\
(0.058)\end{array}$ & $\begin{array}{c}-1.930^{* * *} \\
(0.670)\end{array}$ & $\begin{array}{l}-0.497 \\
(0.397)\end{array}$ & $\begin{array}{l}-0.023 \\
(0.055)\end{array}$ & $\begin{array}{l}-0.053 \\
(0.054)\end{array}$ \\
\hline SE Subsidy by Federal Employment Agency (=1) & $\begin{array}{l}-0.087 \\
(0.312)\end{array}$ & $\begin{array}{l}0.075^{* *} \\
(0.031)\end{array}$ & $\begin{array}{l}-0.431 \\
(0.282)\end{array}$ & $\begin{array}{l}-0.295^{*} \\
(0.166)\end{array}$ & $\begin{array}{l}-0.056^{*} \\
(0.034)\end{array}$ & $\begin{array}{c}-0.085^{* *} \\
(0.037)\end{array}$ \\
\hline IV_06 & $\begin{array}{c}\mathbf{- 5 . 7 9 8}^{* * *} \\
(0.961)\end{array}$ & & & & & \\
\hline IV_08 & $\begin{array}{c}\mathbf{- 0 . 0 7 5} \\
(0.900) \\
\end{array}$ & & & & & \\
\hline Industry/Year Fixed Effects & Yes & Yes & Yes & Yes & Yes & Yes \\
\hline $\begin{array}{l}\text { First-stage F-statistic } \\
\mathrm{N} \\
\text { R-sq. }\end{array}$ & $\begin{array}{l}1256 \\
0.189\end{array}$ & $\begin{array}{c}152.383 \\
1256 \\
0.077 \\
\end{array}$ & $\begin{array}{l}11.84 \\
1039 \\
0.073 \\
\end{array}$ & $\begin{array}{c}12.17 \\
851 \\
0.125 \\
\end{array}$ & $\begin{array}{l}20.8 \\
1291 \\
0.124 \\
\end{array}$ & $\begin{array}{l}20.98 \\
1272 \\
0.151 \\
\end{array}$ \\
\hline $\begin{array}{l}\text { Mean of dependent variable } \\
\text { (abs. value) }\end{array}$ & 4.828 & 0.35 & $\begin{array}{c}10.074 \\
173,661\end{array}$ & $\begin{array}{c}11.271 \\
231,293\end{array}$ & $\begin{array}{l}0.271 \\
0.605\end{array}$ & $\begin{array}{l}0.361 \\
0.847\end{array}$ \\
\hline
\end{tabular}

Notes: Standard errors are shown in parentheses and significance levels are indicated by: *** 1\%,** 5\%, * 10\%. This table shows the IV regression of our outcome variables (motivation for starting up; sales/employment growth after year 1,2) on the founders' actual unemployment duration (AUD) before starting up that is instrumented by IVO6 and IVO8 (Section 3.2). Column 1 shows the first-stage regression of the IV model in column 2. We control for the founders' education, previous work experience, and individual characteristics. We include year and industry (of the startup, see Table 3) fixed effects, and dummies to control for the receipt of self-employment (SE) related subsidies from the Federal Employment Agency and for funding by the KfW (Appendix C.2). Our regression sample consists of non-team founders who became unemployed between 2003 and 2011, were 35 to 65 years old when becoming unemployed, and for whom information on all control variables is available. 
Table A.4: IV Results for Reforms 2006 \& 2008: Actual Unemployment Duration on Motivation of Founder and Firm Outcomes for Non-Manufacturing Sector

\begin{tabular}{|c|c|c|c|c|c|c|}
\hline & $\begin{array}{c}(1) \\
\text { AUD } \\
\text { (in months) }\end{array}$ & $\begin{array}{c}(2) \\
\text { Necessity Motive } \\
(=1)\end{array}$ & $\begin{array}{c}(3) \\
\text { Sales Year } 1 \\
(\log )\end{array}$ & $\begin{array}{c}(4) \\
\text { Sales Year } 2 \\
(\log )\end{array}$ & $\begin{array}{l}(5) \\
\text { FTE Employment } \\
\text { Year 1 (log) }\end{array}$ & $\begin{array}{c}(6) \\
\text { FTE Employment } \\
\text { Year } 2(\log )\end{array}$ \\
\hline Actual unemployment duration (AUD) (in months) & & $\begin{array}{c}\mathbf{0 . 0 1 4} \\
(0.011)\end{array}$ & $\begin{array}{c}\mathbf{0 . 0 0 5} \\
(0.091)\end{array}$ & $\begin{array}{c}\mathbf{- 0 . 1 6 6}^{* *} \\
(0.075)\end{array}$ & $\begin{array}{c}-\mathbf{- 0 . 0 1 1} \\
(0.009)\end{array}$ & $\begin{array}{c}\mathbf{- 0 . 0 2 5} \\
(0.011)\end{array}$ \\
\hline Tertiary degree $(=1)$ & $\begin{array}{l}-0.300 \\
(0.356)\end{array}$ & $\begin{array}{c}-0.083^{* *} \\
(0.035)\end{array}$ & $\begin{array}{l}-0.372 \\
(0.290)\end{array}$ & $\begin{array}{c}0.153 \\
(0.161)\end{array}$ & $\begin{array}{l}0.060^{*} \\
(0.035)\end{array}$ & $\begin{array}{c}0.059 \\
(0.041)\end{array}$ \\
\hline Founder was self-employed before (=1) & $\begin{array}{c}0.252 \\
(0.376)\end{array}$ & $\begin{array}{l}-0.005 \\
(0.042)\end{array}$ & $\begin{array}{c}0.096 \\
(0.346)\end{array}$ & $\begin{array}{l}-0.271 \\
(0.225)\end{array}$ & $\begin{array}{c}0.015 \\
(0.044)\end{array}$ & $\begin{array}{c}0.034 \\
(0.050)\end{array}$ \\
\hline Managerial experience as employee (=1) & $\begin{array}{c}0.160 \\
(0.435)\end{array}$ & $\begin{array}{c}-0.107^{* *} \\
(0.042)\end{array}$ & $\begin{array}{c}0.005 \\
(0.381)\end{array}$ & $\begin{array}{c}0.475^{* * *} \\
(0.182)\end{array}$ & $\begin{array}{l}0.129^{* *} \\
(0.053)\end{array}$ & $\begin{array}{c}0.178^{* * *} \\
(0.060)\end{array}$ \\
\hline Industry experience (in years) & $\begin{array}{c}0.003 \\
(0.017)\end{array}$ & $\begin{array}{c}0.001 \\
(0.002)\end{array}$ & $\begin{array}{c}0.020 \\
(0.016)\end{array}$ & $\begin{array}{c}0.002 \\
(0.012)\end{array}$ & $\begin{array}{c}0.002 \\
(0.002)\end{array}$ & $\begin{array}{c}0.002 \\
(0.002)\end{array}$ \\
\hline Female founder $(=1)$ & $\begin{array}{c}0.355 \\
(0.406)\end{array}$ & $\begin{array}{l}-0.002 \\
(0.042)\end{array}$ & $\begin{array}{c}-0.830^{* *} \\
(0.418)\end{array}$ & $\begin{array}{c}-0.488^{* *} \\
(0.226)\end{array}$ & $\begin{array}{c}0.071 \\
(0.051)\end{array}$ & $\begin{array}{l}0.095^{*} \\
(0.055)\end{array}$ \\
\hline Founder of non-German origin $(=1)$ & $\begin{array}{c}0.189 \\
(0.552)\end{array}$ & $\begin{array}{l}-0.033 \\
(0.063)\end{array}$ & $\begin{array}{c}-1.934^{* * *} \\
(0.710)\end{array}$ & $\begin{array}{l}-0.793^{*} \\
(0.464)\end{array}$ & $\begin{array}{l}-0.079^{*} \\
(0.046)\end{array}$ & $\begin{array}{l}-0.079^{*} \\
(0.047)\end{array}$ \\
\hline SE Subsidy by Federal Employment Agency (=1) & $\begin{array}{l}-0.086 \\
(0.368)\end{array}$ & $\begin{array}{l}0.075^{* *} \\
(0.035)\end{array}$ & $\begin{array}{c}-0.637^{* *} \\
(0.306)\end{array}$ & $\begin{array}{l}-0.283 \\
(0.200)\end{array}$ & $\begin{array}{l}-0.054 \\
(0.035)\end{array}$ & $\begin{array}{l}-0.069^{*} \\
(0.039)\end{array}$ \\
\hline IV_06 & $\begin{array}{c}\mathbf{- 5 . 9 6 2} 2^{* * *} \\
(1.111)\end{array}$ & & & & & \\
\hline IV_08 & $\begin{array}{c}\mathbf{- 0 . 1 0 3} \\
(1.085)\end{array}$ & & & & & \\
\hline Industry/Year Fixed Effects & Yes & Yes & Yes & Yes & Yes & Yes \\
\hline First-stage F-statistic & & 110.896 & 10.01 & 10.13 & 17.61 & 17.7 \\
\hline $\mathrm{N}$ & 999 & 999 & 815 & 661 & 1022 & 1009 \\
\hline R-sq. & 0.209 & 0.090 & 0.078 & 0.128 & 0.168 & 0.169 \\
\hline $\begin{array}{l}\text { Mean of dependent variable } \\
\text { (abs. value for log-terms) }\end{array}$ & 4.926 & 0.352 & $\begin{array}{c}10.21 \\
179,344\end{array}$ & $\begin{array}{c}11.251 \\
237,112\end{array}$ & $\begin{array}{c}0.25 \\
0.549\end{array}$ & $\begin{array}{c}0.329 \\
0.76\end{array}$ \\
\hline
\end{tabular}

Notes: Standard errors are shown in parentheses and significance levels are indicated by: *** $1 \%, * * 5 \%, * 10 \%$. This table shows the IV regression of our outcome variables (motivation for starting up; sales/employment growth after year 1,2) on the founders' actual unemployment duration (AUD) before starting up in the non-manufacturing sector (75\% of the sample) that is instrumented by IVO6 and IVO8 (Section 3.2). Column 1 shows the first-stage regression of the IV model in column 2. We control for the founders' education, previous work experience, and individual characteristics. We include year and industry (of the startup, see Table 3 ) fixed effects, and dummies to control for the receipt of self-employment (SE) related subsidies from the Federal Employment Agency and for funding by the KfW (Appendix C.2). Our regression sample consists of non-team founders who became unemployed between 2003 and 2011 , were 35 to 65 years old when becoming unemployed, and for whom information on all control variables is available. 
Table A.5: Regression Discontinuity Design (RDD) Results: Exogenous Increase of 3 months in PBD at age 50 cutoff

\begin{tabular}{lcccc}
\hline & $(1)$ & $(2)$ & $(3)$ & $(4)$ \\
& $\begin{array}{c}\text { PBD } \\
\text { (in months) }\end{array}$ & $\begin{array}{c}\text { AUD } \\
\text { (in months) }\end{array}$ & $\begin{array}{c}\text { FTE Employment } \\
\text { Year 1 (log) }\end{array}$ & $\begin{array}{c}\text { FTE Employment } \\
\text { Year 2 (log) }\end{array}$ \\
\hline RDD Treatment Effect & $\mathbf{2 . 0 7 9}^{* * *}$ & $\mathbf{1 . 1 8 2}^{*}$ & $\mathbf{- 0 . 1 2 3}$ & $\mathbf{- 0 . 2 4 7}^{* *}$ \\
& $(0.427)$ & $(0.663)$ & $(0.078)$ & $(0.098)$ \\
Tertiary degree (=1) & 0.536 & 0.103 & 0.048 & 0.051 \\
& $(0.333)$ & $(0.404)$ & $(0.065)$ & $(0.060)$ \\
Founder was self-employed & $-0.614^{* *}$ & 0.720 & 0.000 & 0.025 \\
before (=1) & -0.022 & $(0.556)$ & $(0.058)$ & $(0.076)$ \\
Managerial experience & -0.022 & 0.188 & $0.196^{* *}$ & $0.194^{* *}$ \\
as employee (=1) & $(0.269)$ & $(0.389)$ & $(0.071)$ & $(0.075)$ \\
Industry experience & 0.003 & -0.013 & 0.002 & 0.001 \\
(in years) & $(0.010)$ & $(0.021)$ & $(0.003)$ & $(0.003)$ \\
Female founder (=1) & -0.265 & 0.233 & $0.179^{*}$ & 0.097 \\
Founder of & $(0.237)$ & $(0.508)$ & $(0.096)$ & $(0.084)$ \\
non-German origin $(=1)$ & 0.129 & 0.248 & 0.050 & -0.037 \\
SE Subsidy by Federal & $(0.749)$ & $(0.804)$ & $(0.076)$ & $(0.093)$ \\
Employment Agency $(=1)$ & $0.871^{* * *}$ & -0.568 & $-0.140^{* * *}$ & -0.086 \\
\hline Industry/Year Fixed Effects & $(0.241)$ & $(0.549)$ & $(0.042)$ & $(0.058)$ \\
\hline $\mathrm{N}$ & Yes & Yes & Yes & Yes \\
R2 & 419 & 438 & 438 & 428 \\
\hline Mean of dependent variable & 12.254 & 4.49 & 0.279 & 0.165 \\
\hline
\end{tabular}

Notes: Standard errors are shown in parentheses and significance levels are indicated by: *** $1 \%, * *$ $5 \%, * 10 \%$. This table shows the regression discontinuity design (RDD) results for an exogenous increase of 3 months in PBD at the age 50 cutoff in 2008-2011.This table shows the RDD regression of our outcome variables (PBD, AUD, employment growth after year 1,2) on an increase of PBD of around 3 months before starting up (Section 4.2.1). We control for the founders' education; previous work experience; and individual characteristics. We include year and industry (of the startup, see Table 3) fixed effects; and dummies to control for subsidies from the Federal Employment Agency and for funding by the KfW (Appendix C.2). Our regression sample consists of non-team founders who became unemployed between 2008 and 2011, were 45 to 54 years old when becoming unemployed, and for whom information on all control variables is available. 
Table A.6: DiD Results for 2006 Reform: Reduction of at least 3 months in Potential Benefit Duration (PBD)

\begin{tabular}{|c|c|c|c|c|c|c|}
\hline & $\begin{array}{c}(1) \\
\text { AUD } \\
\text { (in months) } \\
\end{array}$ & $\begin{array}{c}(2) \\
\text { Necessity Motive } \\
(=1)\end{array}$ & $\begin{array}{c}(3) \\
\text { Sales Year } 1 \\
(\log )\end{array}$ & $\begin{array}{c}(4) \\
\text { Sales Year } 2 \\
(\log )\end{array}$ & $\begin{array}{l}\text { (5) } \\
\text { FTE Employment } \\
\text { Year } 1(\log )\end{array}$ & $\begin{array}{c}(6) \\
\text { FTE Employment } \\
\text { Year } 2(\log )\end{array}$ \\
\hline $\begin{array}{l}\text { Treatment Effect } \\
=\text { Treated*After }\end{array}$ & $\begin{array}{c}\mathbf{- 3 . 5 8 2}^{* * *} \\
(0.884)\end{array}$ & $\begin{array}{l}-\mathbf{- 0 . 0 9 4} \\
(0.070)\end{array}$ & $\begin{array}{l}\mathbf{- 0 . 2 5 3} \\
(0.494)\end{array}$ & $\begin{array}{c}\mathbf{0 . 4 1 3} \\
(0.345)\end{array}$ & $\begin{array}{l}-\mathbf{- 0 . 0 4 1} \\
(0.062)\end{array}$ & $\begin{array}{l}-\mathbf{0 . 0 0 5} \\
(0.072)\end{array}$ \\
\hline Treated & $\begin{array}{c}4.254^{* * *} \\
(0.853)\end{array}$ & $\begin{array}{c}0.232^{* * *} \\
(0.063)\end{array}$ & $\begin{array}{c}0.142 \\
(0.419)\end{array}$ & $\begin{array}{l}-0.491 \\
(0.320)\end{array}$ & $\begin{array}{c}0.043 \\
(0.054)\end{array}$ & $\begin{array}{l}-0.013 \\
(0.064)\end{array}$ \\
\hline After & $\begin{array}{c}-5.091^{* * *} \\
(0.605)\end{array}$ & $\begin{array}{l}-0.087 \\
(0.071)\end{array}$ & $\begin{array}{l}-0.093 \\
(0.517)\end{array}$ & $\begin{array}{c}0.417 \\
(0.378)\end{array}$ & $\begin{array}{c}0.030 \\
(0.062)\end{array}$ & $\begin{array}{l}0.142^{*} \\
(0.074)\end{array}$ \\
\hline Tertiary degree $(=1)$ & $\begin{array}{l}-0.217 \\
(0.294)\end{array}$ & $\begin{array}{c}-0.068^{* *} \\
(0.032)\end{array}$ & $\begin{array}{l}-0.679^{* *} \\
(0.289)\end{array}$ & $\begin{array}{c}0.007 \\
(0.173)\end{array}$ & $\begin{array}{l}0.072^{* *} \\
(0.034)\end{array}$ & $\begin{array}{l}0.074^{*} \\
(0.040)\end{array}$ \\
\hline Founder was self-employed before (=1) & $\begin{array}{c}0.061 \\
(0.335)\end{array}$ & $\begin{array}{l}-0.023 \\
(0.037)\end{array}$ & $\begin{array}{l}-0.016 \\
(0.343)\end{array}$ & $\begin{array}{l}-0.082 \\
(0.213)\end{array}$ & $\begin{array}{l}-0.012 \\
(0.040)\end{array}$ & $\begin{array}{l}-0.019 \\
(0.045)\end{array}$ \\
\hline Managerial experience as employee (=1) & $\begin{array}{c}0.179 \\
(0.368)\end{array}$ & $\begin{array}{l}-0.072^{*} \\
(0.039)\end{array}$ & $\begin{array}{c}0.150 \\
(0.358)\end{array}$ & $\begin{array}{c}0.592^{* * *} \\
(0.169)\end{array}$ & $\begin{array}{c}0.131^{* * *} \\
(0.050)\end{array}$ & $\begin{array}{l}0.169^{* * *} \\
(0.058)\end{array}$ \\
\hline Industry experience (in years) & $\begin{array}{l}-0.001 \\
(0.015)\end{array}$ & $\begin{array}{c}0.001 \\
(0.002)\end{array}$ & $\begin{array}{l}0.034^{* *} \\
(0.015)\end{array}$ & $\begin{array}{c}0.006 \\
(0.010)\end{array}$ & $\begin{array}{c}0.001 \\
(0.002)\end{array}$ & $\begin{array}{c}0.001 \\
(0.002)\end{array}$ \\
\hline Female founder $(=1)$ & $\begin{array}{c}0.112 \\
(0.337)\end{array}$ & $\begin{array}{c}0.003 \\
(0.039)\end{array}$ & $\begin{array}{c}-1.090^{* * *} \\
(0.409)\end{array}$ & $\begin{array}{l}-0.358 \\
(0.218)\end{array}$ & $\begin{array}{c}0.064 \\
(0.047)\end{array}$ & $\begin{array}{l}0.102^{*} \\
(0.053)\end{array}$ \\
\hline Founder of non-German origin $(=1)$ & $\begin{array}{c}0.253 \\
(0.479)\end{array}$ & $\begin{array}{c}0.042 \\
(0.060)\end{array}$ & $\begin{array}{c}-1.891^{\text {*** }} \\
(0.676)\end{array}$ & $\begin{array}{l}-0.572 \\
(0.437)\end{array}$ & $\begin{array}{l}-0.023 \\
(0.056)\end{array}$ & $\begin{array}{l}-0.057 \\
(0.057)\end{array}$ \\
\hline SE Subsidy by Federal Employment Agency (=1) & $\begin{array}{l}-0.157 \\
(0.297) \\
\end{array}$ & $\begin{array}{c}0.072^{* *} \\
(0.032)\end{array}$ & $\begin{array}{c}-0.427 \\
(0.282) \\
\end{array}$ & $\begin{array}{l}-0.285^{*} \\
(0.169) \\
\end{array}$ & $\begin{array}{c}-0.055 \\
(0.034)\end{array}$ & $\begin{array}{c}-0.083^{* *} \\
(0.038)\end{array}$ \\
\hline Industry/Year Fixed Effects & Yes & Yes & Yes & Yes & Yes & Yes \\
\hline $\begin{array}{l}\mathrm{N} \\
\mathrm{R} \text {-sq. }\end{array}$ & $\begin{array}{c}1291 \\
0.231 \\
\end{array}$ & $\begin{array}{c}1256 \\
0.068 \\
\end{array}$ & $\begin{array}{r}1039 \\
0.098 \\
\end{array}$ & $\begin{array}{c}851 \\
0.094 \\
\end{array}$ & $\begin{array}{c}1291 \\
0.132 \\
\end{array}$ & $\begin{array}{c}1272 \\
0.133 \\
\end{array}$ \\
\hline $\begin{array}{l}\text { Mean of dependent variable } \\
\text { (abs. value for log-terms) }\end{array}$ & 145.637 & 0.35 & $\begin{array}{c}10.074 \\
173,661\end{array}$ & $\begin{array}{c}11.271 \\
231,293\end{array}$ & $\begin{array}{l}0.271 \\
0.605\end{array}$ & $\begin{array}{l}0.361 \\
0.847\end{array}$ \\
\hline
\end{tabular}

Notes: Standard errors are shown in parentheses and significance levels are indicated by: $* * * 1 \%, * * 5 \%, * 10 \%$. This table shows the DiD regression of our outcome variables (actual unemployment duration (AUD), motivation for starting up; sales/employment growth after year 1,2) on a decrease of PBD of around 6 months, before starting up (Section 4.2.3). We control for the founders' education, previous work experience, and individual characteristics. We include year and industry (of the startup, see Table 3) fixed effects, and dummies to control for the receipt of self-employment (SE) related subsidies from the Federal Employment Agency and for funding by the KfW (Appendix C.2). Our regression sample consists of non-team founders who became unemployed between 2003 and 2011, were 35 to 65 years old when becoming unemployed, and for whom information on all control variables is available. 
Table A.7: DiD Results for 2006 Reform: Reduction of at least 3 months in Potential Benefit Duration (PBD) focusing on the Non-Manufacturing Sector

\begin{tabular}{|c|c|c|c|c|c|c|}
\hline & $\begin{array}{c}(1) \\
\text { AUD } \\
\text { (in months) } \\
\end{array}$ & $\begin{array}{c}(2) \\
\text { Necessity Motive } \\
(=1)\end{array}$ & $\begin{array}{c}(3) \\
\text { Sales Year } 1 \\
(\log )\end{array}$ & $\begin{array}{c}(4) \\
\text { Sales Year } 2 \\
(\log )\end{array}$ & $\begin{array}{l}\text { (5) } \\
\text { FTE Employment } \\
\text { Year } 1(\log )\end{array}$ & $\begin{array}{c}(6) \\
\text { FTE Employment } \\
\text { Year } 2(\log )\end{array}$ \\
\hline $\begin{array}{l}\text { Treatment Effect } \\
=\text { Treated*After }\end{array}$ & $\begin{array}{c}\mathbf{- 3 . 9 9 7 * * *} \\
(1.006)\end{array}$ & $\begin{array}{l}-\mathbf{- 0 . 0 7 0} \\
(0.078)\end{array}$ & $\begin{array}{c}\mathbf{0 . 0 9 0} \\
(0.511)\end{array}$ & $\begin{array}{l}\mathbf{0 . 6 9 8}^{*} \\
(0.415)\end{array}$ & $\begin{array}{c}\mathbf{0 . 0 4 1} \\
(0.058)\end{array}$ & $\begin{array}{l}\mathbf{0 . 0 8 7} \\
(0.071)\end{array}$ \\
\hline Treated & $\begin{array}{c}4.885^{* * *} \\
(0.971)\end{array}$ & $\begin{array}{c}0.201^{* * *} \\
(0.071)\end{array}$ & $\begin{array}{l}-0.231 \\
(0.427)\end{array}$ & $\begin{array}{c}-0.776^{* *} \\
(0.391)\end{array}$ & $\begin{array}{c}-0.033 \\
(0.048)\end{array}$ & $\begin{array}{l}-0.096 \\
(0.061)\end{array}$ \\
\hline After & $\begin{array}{c}-5.004^{* * *} \\
(0.686)\end{array}$ & $\begin{array}{l}-0.032 \\
(0.082)\end{array}$ & $\begin{array}{c}-0.302 \\
(0.600)\end{array}$ & $\begin{array}{c}0.442 \\
(0.450)\end{array}$ & $\begin{array}{c}0.063 \\
(0.062)\end{array}$ & $\begin{array}{l}0.159^{* *} \\
(0.074)\end{array}$ \\
\hline Tertiary degree $(=1)$ & $\begin{array}{l}-0.222 \\
(0.337)\end{array}$ & $\begin{array}{c}-0.084^{* *} \\
(0.036)\end{array}$ & $\begin{array}{c}-0.381 \\
(0.295)\end{array}$ & $\begin{array}{c}0.178 \\
(0.173)\end{array}$ & $\begin{array}{c}0.059 \\
(0.036)\end{array}$ & $\begin{array}{c}0.060 \\
(0.042)\end{array}$ \\
\hline Founder was self-employed before (=1) & $\begin{array}{c}0.203 \\
(0.356)\end{array}$ & $\begin{array}{c}0.002 \\
(0.042)\end{array}$ & $\begin{array}{c}0.073 \\
(0.354)\end{array}$ & $\begin{array}{l}-0.220 \\
(0.233)\end{array}$ & $\begin{array}{c}0.009 \\
(0.045)\end{array}$ & $\begin{array}{c}0.029 \\
(0.052)\end{array}$ \\
\hline Managerial experience as employee (=1) & $\begin{array}{c}0.226 \\
(0.419)\end{array}$ & $\begin{array}{c}-0.103^{* *} \\
(0.043)\end{array}$ & $\begin{array}{c}0.002 \\
(0.384)\end{array}$ & $\begin{array}{l}0.412^{* *} \\
(0.190)\end{array}$ & $\begin{array}{l}0.125^{* *} \\
(0.054)\end{array}$ & $\begin{array}{c}0.172^{* * *} \\
(0.062)\end{array}$ \\
\hline Industry experience (in years) & $\begin{array}{c}0.006 \\
(0.017)\end{array}$ & $\begin{array}{c}0.001 \\
(0.002)\end{array}$ & $\begin{array}{c}0.019 \\
(0.016)\end{array}$ & $\begin{array}{c}0.003 \\
(0.012)\end{array}$ & $\begin{array}{c}0.001 \\
(0.002)\end{array}$ & $\begin{array}{c}0.002 \\
(0.002)\end{array}$ \\
\hline Female founder $(=1)$ & $\begin{array}{c}0.290 \\
(0.384)\end{array}$ & $\begin{array}{c}0.001 \\
(0.043)\end{array}$ & $\begin{array}{c}-0.829^{* *} \\
(0.421)\end{array}$ & $\begin{array}{c}-0.525^{* *} \\
(0.240)\end{array}$ & $\begin{array}{c}0.069 \\
(0.052)\end{array}$ & $\begin{array}{c}0.090 \\
(0.057)\end{array}$ \\
\hline Founder of non-German origin $(=1)$ & $\begin{array}{c}0.255 \\
(0.517)\end{array}$ & $\begin{array}{l}-0.032 \\
(0.065)\end{array}$ & $\begin{array}{c}-1.920^{* * *} \\
(0.721)\end{array}$ & $\begin{array}{c}-0.878^{*} \\
(0.518)\end{array}$ & $\begin{array}{c}-0.079^{*} \\
(0.047)\end{array}$ & $\begin{array}{l}-0.086^{*} \\
(0.050)\end{array}$ \\
\hline SE Subsidy by Federal Employment Agency (=1) & $\begin{array}{c}-0.142 \\
(0.348) \\
\end{array}$ & $\begin{array}{c}0.074^{* *} \\
(0.037)\end{array}$ & $\begin{array}{c}-0.634^{* *} \\
(0.311)\end{array}$ & $\begin{array}{c}-0.266 \\
(0.201) \\
\end{array}$ & $\begin{array}{c}-0.051 \\
(0.036)\end{array}$ & $\begin{array}{c}-0.064 \\
(0.041) \\
\end{array}$ \\
\hline Industry/Year Fixed Effects & Yes & Yes & Yes & Yes & Yes & Yes \\
\hline $\begin{array}{l}\mathrm{N} \\
\mathrm{R} \text {-sq. }\end{array}$ & $\begin{array}{l}1022 \\
0.252 \\
\end{array}$ & $\begin{array}{c}999 \\
0.071 \\
\end{array}$ & $\begin{array}{c}815 \\
0.080 \\
\end{array}$ & $\begin{array}{c}661 \\
0.112 \\
\end{array}$ & $\begin{array}{l}1022 \\
0.147 \\
\end{array}$ & $\begin{array}{r}1009 \\
0.141 \\
\end{array}$ \\
\hline $\begin{array}{l}\text { Mean of dependent variable } \\
\text { (abs. value for log-terms) }\end{array}$ & 149.003 & 0.352 & $\begin{array}{c}10.21 \\
179,344\end{array}$ & $\begin{array}{c}11.251 \\
237,112\end{array}$ & $\begin{array}{c}0.25 \\
0.549\end{array}$ & $\begin{array}{c}0.329 \\
0.76\end{array}$ \\
\hline
\end{tabular}

Notes: Standard errors are shown in parentheses and significance levels are indicated by: *** 1\%,** 5\%,*10\%. This table shows the DiD regression of our outcome variables (actual unemployment duration (AUD), motivation for starting up; sales/employment growth after year 1,2) on a decrease of PBD of around 6 months (Section 4.2.3), before starting up in the non-manufacturing sector (75\% of the sample). We control for the founders' education, previous work experience, and individual characteristics. We include year and industry (of the startup, see Table 3) fixed effects, and dummies to control for the receipt of self-employment (SE) related subsidies from the Federal Employment Agency and for funding by the KfW (Appendix C.2). Our regression sample consists of non-team founders who became unemployed between 2003 and 2011, were 35 to 65 years old when becoming unemployed, and for whom information on all control variables is available. 
Table A.8: OLS - Actual Unemployment Duration (AUD) - Controlled vs. Uncontrolled

\begin{tabular}{|c|c|c|c|c|c|c|c|c|c|c|}
\hline \multirow[b]{2}{*}{$\begin{array}{l}\text { Actual unemployment duration (AUD) } \\
\text { (in months) }\end{array}$} & \multicolumn{2}{|c|}{$\begin{array}{c}(1) \\
\text { Necessity Motive } \\
(=1)\end{array}$} & \multicolumn{2}{|c|}{$\begin{array}{c}(2) \\
\text { Sales Year } 1 \\
(\log )\end{array}$} & \multicolumn{2}{|c|}{$\begin{array}{l}(3) \\
\text { Sales Year } 2 \\
\quad(\log )\end{array}$} & \multicolumn{2}{|c|}{$\begin{array}{l}(4) \\
\text { FTE Employment } \\
\text { Year } 1(\log )\end{array}$} & \multicolumn{2}{|c|}{$\begin{array}{l}(5) \\
\text { FTE Employment } \\
\text { Year } 2(\log )\end{array}$} \\
\hline & $\begin{array}{c}\mathbf{0 . 0 1 7}^{* * *} \\
(0.003)\end{array}$ & $\begin{array}{c}\mathbf{0 . 0 1 7}^{* * *} \\
(0.003)\end{array}$ & $\begin{array}{c}-\mathbf{- 0 . 1 3 9} 9^{* * *} \\
(0.027)\end{array}$ & $\begin{array}{c}-\mathbf{- 0 . 1 4 1} \\
(0.028)\end{array}$ & $\begin{array}{c}\mathbf{- 0 . 0 9 6}^{* * *} \\
(0.018)\end{array}$ & $\begin{array}{c}-\mathbf{- 0 . 1 0 4}^{* * *} \\
(0.021)\end{array}$ & $\begin{array}{c}\mathbf{- 0 . 0 1 6}^{* * *} \\
(0.003)\end{array}$ & $\begin{array}{c}\mathbf{- 0 . 0 1 8}^{* * *} \\
(0.003)\end{array}$ & $\begin{array}{c}-\mathbf{- 0 . 0 2 3}^{* * *} \\
(0.003)\end{array}$ & $\begin{array}{c}\mathbf{- 0 . 0 2 4}^{* * *} \\
(0.003)\end{array}$ \\
\hline CONTROLS & Yes & No & Yes & No & Yes & No & Yes & No & Yes & No \\
\hline $\begin{array}{l}\mathrm{N} \\
\mathrm{R} \text {-sq. }\end{array}$ & $\begin{array}{r}1256 \\
0.063\end{array}$ & $\begin{array}{l}1256 \\
0.026\end{array}$ & $\begin{array}{l}1039 \\
0.122\end{array}$ & $\begin{array}{l}1039 \\
0.028\end{array}$ & $\begin{array}{c}851 \\
0.126\end{array}$ & $\begin{array}{c}851 \\
0.049\end{array}$ & $\begin{array}{l}1291 \\
0.150\end{array}$ & $\begin{array}{r}1291 \\
0.023\end{array}$ & $\begin{array}{l}1272 \\
0.158\end{array}$ & $\begin{array}{r}1272 \\
0.034\end{array}$ \\
\hline $\begin{array}{l}\text { Mean of dependent variable } \\
\text { (abs. value for log-terms) }\end{array}$ & 0.35 & 0.35 & $\begin{array}{c}10.074 \\
173,661\end{array}$ & $\begin{array}{c}10.074 \\
173,661\end{array}$ & $\begin{array}{c}11.271 \\
231,293\end{array}$ & $\begin{array}{c}11.271 \\
231,293\end{array}$ & $\begin{array}{l}0.271 \\
0.605\end{array}$ & $\begin{array}{l}0.271 \\
0.605\end{array}$ & $\begin{array}{l}0.361 \\
0.847\end{array}$ & $\begin{array}{l}0.361 \\
0.847\end{array}$ \\
\hline
\end{tabular}

Table A.9: OLS - Potential Benefit Duration (PBD) - Controlled vs. Uncontrolled

\begin{tabular}{|c|c|c|c|c|c|c|c|c|c|c|c|c|}
\hline \multirow[b]{2}{*}{$\begin{array}{l}\text { Potential benefit duration (PBD) } \\
\text { (in months) }\end{array}$} & \multicolumn{2}{|c|}{$\begin{array}{c}\text { (1) } \\
\text { AUD } \\
\text { (in months) }\end{array}$} & \multicolumn{2}{|c|}{$\begin{array}{c}(2) \\
\text { Necessity Motive } \\
(=1)\end{array}$} & \multicolumn{2}{|c|}{$\begin{array}{c}(3) \\
\text { Sales Year } 1 \\
(\log )\end{array}$} & \multicolumn{2}{|c|}{$\begin{array}{c}(4) \\
\text { Sales Year } 2 \\
(\log )\end{array}$} & \multicolumn{2}{|c|}{$\begin{array}{c}(5) \\
\text { FTE Employment } \\
\text { Year } 1(\log )\end{array}$} & \multicolumn{2}{|c|}{$\begin{array}{c}(6) \\
\text { FTE Employment } \\
\text { Year } 2(\log )\end{array}$} \\
\hline & $\begin{array}{c}\mathbf{0 . 4 7 1}^{* * *} \\
(0.048)\end{array}$ & $\begin{array}{c}\mathbf{0 . 4 9 8}^{* * *} \\
(0.048) \\
\end{array}$ & $\begin{array}{c}\mathbf{0 . 0 2 3}^{* * *} \\
(0.003)\end{array}$ & $\begin{array}{c}\mathbf{0 . 0 2 3}^{* * *} \\
(0.003)\end{array}$ & $\begin{array}{l}\mathbf{- 0 . 0 3 6} \\
(0.024)\end{array}$ & $\begin{array}{l}-\mathbf{- 0 . 0 4 5}^{*} \\
(0.024)\end{array}$ & $\begin{array}{l}\mathbf{- 0 . 0 4 9}^{* *} \\
(0.022)\end{array}$ & $\begin{array}{c}\mathbf{- 0 . 0 5 3}^{* *} \\
(0.022)\end{array}$ & $\begin{array}{l}\mathbf{- 0 . 0 0 4} \\
(0.004)\end{array}$ & $\begin{array}{c}-\mathbf{- 0 . 0 0 8}^{* *} \\
(0.004)\end{array}$ & $\begin{array}{c}-\mathbf{- 0 . 0 0 9}^{* *} \\
(0.004)\end{array}$ & $\begin{array}{c}\mathbf{- 0 . 0 1 3}^{* * *} \\
(0.004)\end{array}$ \\
\hline $\mathrm{CON}$ & Yes & No & Yes & No & Yes & No & Yes & No & Yes & \begin{tabular}{|l} 
No \\
\end{tabular} & Yes & No \\
\hline $\begin{array}{l}\mathrm{N} \\
\mathrm{R} \text {-sq. }\end{array}$ & & & & & & & & & & & & $\begin{array}{l}1272 \\
0.008\end{array}$ \\
\hline $\begin{array}{l}\text { Mean of dependent variable } \\
\text { (abs. value for log-terms) }\end{array}$ & 4 & 4 & 0 & 0 & $\begin{array}{c}10.074 \\
173,661\end{array}$ & $\begin{array}{c}10.074 \\
173,661\end{array}$ & $\begin{array}{c}11.271 \\
231,293\end{array}$ & $\begin{array}{c}11.271 \\
231,293\end{array}$ & $\begin{array}{l}0.271 \\
0.605\end{array}$ & $\begin{array}{l}0.271 \\
0.605\end{array}$ & $\begin{array}{l}0.361 \\
0.847\end{array}$ & $\begin{array}{l}0.361 \\
0.847\end{array}$ \\
\hline
\end{tabular}

Notes: Standard errors are shown in parentheses and significance levels are indicated by: $* * * 1 \%, * * 5 \%, * 10 \%$. These tables show the OLS regression of our main outcome variables (motivation for starting up; sales/employment growth after year 1,2) on the founders' actual and potential benefit duration (AUD and PBD) before starting up. We analyze to which extent controls for founders' education, previous work experience and individual characteristics affect results compared to the standard case without controls. The fact that there are no remarkable differences shows that composition effects are limited. 
Table A.10: IV - Actual Unemployment Duration (AUD) - Controlled vs. Uncontrolled

\begin{tabular}{|c|c|c|c|c|c|c|c|c|c|c|c|c|}
\hline \multirow[b]{2}{*}{$\begin{array}{l}\text { Actual unemployment duration (AUD) } \\
\text { (in months) }\end{array}$} & \multicolumn{2}{|c|}{$\begin{array}{c}\text { (1) } \\
\text { AUD } \\
\text { (in months) } \\
\end{array}$} & \multicolumn{2}{|c|}{$\begin{array}{c}(2) \\
\text { Necessity Motive } \\
(=1)\end{array}$} & \multicolumn{2}{|c|}{$\begin{array}{l}(3) \\
\text { Sales Year } 1 \\
\quad(\log )\end{array}$} & \multicolumn{2}{|c|}{$\begin{array}{l}(4) \\
\text { Sales Year } 2 \\
\quad(\log )\end{array}$} & \multicolumn{2}{|c|}{$\begin{array}{c}(5) \\
\text { FTE Employment } \\
\text { Year } 1(\log )\end{array}$} & \multicolumn{2}{|c|}{$\begin{array}{c}(6) \\
\text { FTE Employment } \\
\text { Year 2(log) }\end{array}$} \\
\hline & & & $\begin{array}{l}\mathbf{0 . 0 2 2}^{* *} \\
(0.010)\end{array}$ & $\begin{array}{c}\mathbf{0 . 0 3 0}^{* * *} \\
(0.010)\end{array}$ & $\begin{array}{c}\mathbf{0 . 0 6 0} \\
(0.095)\end{array}$ & $\begin{array}{c}\mathbf{0 . 1 4 5} \\
(0.092)\end{array}$ & $\begin{array}{l}\mathbf{- 0 . 1 1 8}^{*} \\
(0.063)\end{array}$ & $\begin{array}{l}-\mathbf{0 . 1 1 5} \\
(0.066)\end{array}$ & $\begin{array}{c}\mathbf{0 . 0 0 5} \\
(0.011)\end{array}$ & $\begin{array}{l}\mathbf{- 0 . 0 0 8} \\
(0.010)\end{array}$ & $\begin{array}{l}\mathbf{- 0 . 0 1 0} \\
(0.012)\end{array}$ & $\begin{array}{l}\mathbf{- 0 . 0 1 7} \\
(0.011)\end{array}$ \\
\hline IV_06 & $\begin{array}{c}\mathbf{- 5 . 8 1 5} \\
(0.921) \\
\end{array}$ & $\begin{array}{c}\mathbf{- 5 . 6 9 5} 5^{* * *} \\
(0.846)\end{array}$ & & & & & & & & & & \\
\hline CONTROLS & Yes & No & Yes & No & Yes & No & Yes & No & Yes & No & Yes & No \\
\hline $\begin{array}{l}\text { First-stage F-statistic } \\
\mathrm{N} \\
\text { R-sq. }\end{array}$ & $\begin{array}{l}1256 \\
0.189\end{array}$ & $\begin{array}{l}1256 \\
0.135\end{array}$ & $\begin{array}{c}39.831 \\
1256 \\
0.075\end{array}$ & $\begin{array}{l}45.318 \\
1256 \\
0.021\end{array}$ & $\begin{array}{c}23.487 \\
1039 \\
0.072\end{array}$ & $\begin{array}{c}26.687 \\
1039 \\
.\end{array}$ & $\begin{array}{c}24.016 \\
851 \\
0.124\end{array}$ & $\begin{array}{c}23.626 \\
851 \\
0.048\end{array}$ & $\begin{array}{c}40.992 \\
1291 \\
0.120\end{array}$ & $\begin{array}{c}45.866 \\
1291 \\
0.016\end{array}$ & $\begin{array}{l}41.07 \\
1272 \\
0.149\end{array}$ & $\begin{array}{c}45.886 \\
1272 \\
0.032\end{array}$ \\
\hline $\begin{array}{l}\text { Mean of dependent variable } \\
\text { (abs. value for log-terms) }\end{array}$ & 4.828 & 4.828 & 0.35 & 0.35 & $\begin{array}{c}10.074 \\
173,661\end{array}$ & $\begin{array}{c}10.074 \\
173,661\end{array}$ & $\begin{array}{c}11.271 \\
231,293\end{array}$ & $\begin{array}{c}11.271 \\
231,293\end{array}$ & $\begin{array}{l}0.271 \\
0.605\end{array}$ & $\begin{array}{l}0.271 \\
0.605\end{array}$ & $\begin{array}{l}0.361 \\
0.847\end{array}$ & $\begin{array}{l}0.361 \\
0.847\end{array}$ \\
\hline
\end{tabular}

Table A.11: IV - Potential Benefit Duration (PBD) - Controlled vs. Uncontrolled

\begin{tabular}{|c|c|c|c|c|c|c|c|c|c|c|c|c|c|c|}
\hline \multirow[b]{2}{*}{$\begin{array}{l}\text { Potential benefit duration (PBD) } \\
\text { (in months) }\end{array}$} & \multicolumn{2}{|c|}{$\begin{array}{c}\text { (1) } \\
\text { PBD } \\
\text { (in months) } \\
\end{array}$} & \multicolumn{2}{|c|}{$\begin{array}{c}(2) \\
\text { AUD } \\
\text { (in months) } \\
\end{array}$} & \multicolumn{2}{|c|}{$\begin{array}{c}(3) \\
\text { Necessity Motive } \\
(=1)\end{array}$} & \multicolumn{2}{|c|}{$\begin{array}{l}(4) \\
\text { Sales Year } 1 \\
\quad(\log )\end{array}$} & \multicolumn{2}{|c|}{$\begin{array}{l}(5) \\
\text { Sales Year } 2 \\
\quad(\log )\end{array}$} & \multicolumn{2}{|c|}{$\begin{array}{c}(6) \\
\text { FTE Employment } \\
\text { Year } 1(\log )\end{array}$} & \multicolumn{2}{|c|}{$\begin{array}{c}(7) \\
\text { FTE Employment } \\
\text { Year } 2(\log )\end{array}$} \\
\hline & & & $\begin{array}{c}\mathbf{0 . 6 6 1}^{* * *} \\
(0.094)\end{array}$ & $\begin{array}{c}\mathbf{0 . 6 7 7 ^ { * * * }} \\
(0.094)\end{array}$ & $\begin{array}{l}\mathbf{0 . 0 1 5}^{* *} \\
(0.007)\end{array}$ & $\begin{array}{c}\mathbf{0 . 0 2 0}^{* * *} \\
(0.006)\end{array}$ & $\begin{array}{c}\mathbf{0 . 0 3 4} \\
(0.052)\end{array}$ & $\begin{array}{l}\mathbf{0 . 0 8 4}^{*} \\
(0.048)\end{array}$ & $\begin{aligned}-\mathbf{- 0 . 0 7 2}^{*} \\
(0.039)\end{aligned}$ & $\begin{array}{l}-\mathbf{- 0 . 0 6 8}^{*} \\
(0.040)\end{array}$ & $\begin{array}{c}\mathbf{0 . 0 0 3} \\
(0.007)\end{array}$ & $\begin{array}{l}\mathbf{- 0 . 0 0 5} \\
(0.007)\end{array}$ & $\begin{array}{l}-\mathbf{0 . 0 0 6} \\
(0.008)\end{array}$ & $\begin{array}{l}\mathbf{- 0 . 0 1 2} \\
(0.007)\end{array}$ \\
\hline IV_06 & $\begin{array}{c}\mathbf{- 8 . 7 4 3}^{* * *} \\
(0.505)\end{array}$ & $\begin{array}{c}\mathbf{- 8 . 3 2 2}^{* * *} \\
(0.459)\end{array}$ & & & & & & & & & & & & \\
\hline CONTROLS & Yes & No & Yes & No & Yes & No & Yes & No & Yes & No & Yes & No & Yes & No \\
\hline $\mathrm{N}$ & 1291 & 1291 & 1291 & 1291 & 1256 & 1256 & 1039 & 1039 & 851 & 851 & 1291 & 1291 & 1272 & 1272 \\
\hline $\mathrm{R}$-sq. & 0.470 & 0.434 & 0.234 & 0.194 & 0.083 & 0.049 & 0.094 & . & 0.094 & 0.011 & 0.130 & 0.004 & 0.134 & 0.009 \\
\hline $\begin{array}{l}\text { Mean of dependent variable } \\
\text { (abs. value for log-terms) }\end{array}$ & 12.324 & 12.324 & 4.785 & 4.785 & 0.35 & 0.35 & $\begin{array}{c}10.074 \\
173.661\end{array}$ & $\begin{array}{c}10.074 \\
173,661\end{array}$ & $\begin{array}{c}11.271 \\
231.293\end{array}$ & $\begin{array}{c}11.271 \\
231.293\end{array}$ & $\begin{array}{l}0.271 \\
0.605\end{array}$ & $\begin{array}{l}0.271 \\
0.605\end{array}$ & $\begin{array}{l}0.361 \\
0.847\end{array}$ & $\begin{array}{l}0.361 \\
0.847\end{array}$ \\
\hline
\end{tabular}

Notes: Standard errors are shown in parentheses and significance levels are indicated by: *** 1\%,**5\%,*10\%. These tables show the IV regression of our outcome variables (motivation for starting up; sales/employment growth after year 1,2) on the founders' actual and potential benefit duration (AUD and PBD) before starting up that are instrumented by IVO6 (Section 3.2). We analyze to which extent controls for founders' education, previous work experience and individual characteristics affect results compared to the standard case without controls. The fact that there are no remarkable differences shows that composition effects are limited. 


\section{B Appendix: Technical Details of Data Construction}

\section{B.1 Details on the created linked dataset and the matching procedure}

The IAB/ZEW Start-Up Panel is a random sample drawn from the "universe" of the Mannheim Enterprise Panel ("MUP"). The MUP is collected by Creditreform (Germany's largest credit rating agency) and processed by ZEW. It covers basic information (addresses, phone numbers, industry, incorporation status, survival) about all "economically active" firms in Germany. This is guaranteed by automated synchronization of data with official commercial registers and the Chambers of Industry and Commerce (IHKs), as well as by active search for new firms by local Creditreform offices, which usually also receive a request for conducting a credit rating when new firms enter the market.

Only independent new firms are sampled for the Start-Up Panel survey, which means that all startups are included, except: subsidiaries or new establishments of existing firms and business succession (also in case of insolvency) are excluded. In contrast, joint ventures and franchise are included. Moreover, a maximum of $75 \%$ of a firm's shares may be held by other firms. In conclusion, the interviewee entering into the Start-Up Panel is financially engaged in the firm and usually the single founder or one member of a founding team. The Start-Up Panel is a stratified random sample. Stratification is based on KfW funding (until 2011), founding year, and industry. A detailed first interview is supposed to take place within one year after the firm has been started. Only a small proportion of firms is first sampled up to three years after foundation to balance small stratification cells (they can be excluded). Shorter follow-up surveys are then conducted in subsequent years. Each startup stays in the sample for up to seven interviews or until they drop out by missing two subsequent interviews. All information is retrieved by computer-assisted telephone interviews.

This firm-level survey data is matched to person-specific employment register data on the startups' founders and employees. The employment register data contain information on all employees who are subject to social security contributions in Germany. This includes apprentices, interns, and employees in marginal part-time employment. All notifications on an individual's employment or unemployment spell can be linked via a unique person-specific identifier to construct the employment history for each employee. Another identifier allows matching the employees to establishments. However, there is no unique identifier to match establishments to firms. Therefore, we matched establishments to firms in the IAB/ZEW Start-Up Panel using a text search algorithm via firm/establishment names and addresses. The text search algorithm is described in detail in Appendix B of Czarnitzki et al. (2015) and has proved to deliver very reliable results in various settings. In the matching procedure we were able to find about $90 \%$ of the firms in the IAB/ZEW Start-Up Panel which reported having employees in the yearly telephone surveys. We removed firms from the sample which reported that they had employees but which we were unable to detect during the matching procedure. In addition, to safeguard against false matches, all matches were double-checked manually and we excluded matches in the $1^{s t}$ and $100^{t h}$ percentile of the difference between self-reported and process-generated firm sizes from the sample. The correlation coefficient between self-reported and process-generated firm sizes in the final firm-year panel dataset is slightly above 0.95 .

Since founders are usually not subject to social insurance contributions in their own companies, they are not reported as employees of their ventures in the register data. Therefore, we matched labor market histories of all founders from the IAB/ZEW Start-up Panel based on their names, birth dates, and additional geographical information. We were able to find matching employment register data for about $80 \%$ of the founders. Given that not all founders were necessarily employed, i.e. subject to social insurance in Germany previously (e.g. as they have always been self-employed), this is a very high ratio of matched individuals. Importantly, any bias due to unmatched individuals that might still arise should be particularly small for unemployed founders, who are in the focus of this study. To qualify for UI benefits, individuals need to have been previously employed subject to social insurance (cf. Section 3.1). In addition, all spells with UI benefit receipts are observable in the register data. 


\section{Appendix: Institutional Details}

\section{C.1 Labour Market Reforms in Germany}

In this paper, we exploit parts of the big labor market reforms enacted in Germany between 2003 and 2005 that are known as Hartz reforms (see e.g. Hartung et al. (2018), Petrunyk and Pfeifer (2018), or Price (2019), who evaluate theses reforms).

- In 2003, the first two parts of the labor market reform were passed: the first measure (Hartz I) liberalized temporary work, allowing firms to hire workers from temporary work agencies for short-term periods. The second measure package (Hartz II) reduced the regulations on marginal employment and introduced an additional form of social security tax-favored employment (midijobs). Moreover, it created new subsidies for unemployed workers starting their own businesses (Ich-AGs). The latter program ended in 2006 and was replaced by a new startup subsidy scheme (Gründungszuschuss, see Appendix C.2).

- In 2004, the third reform package (Hartz III) renewed the structure and role of the German Federal Employment Agency. Most importantly, the original placement agencies (Arbeitsämter) and social security offices (Sozialämter) were merged into single institutions (Arbeitsagenturen). Moreover, additional job centers were set up in many municipalities. Finally, case managers were introduced to have one person in charge of assisting unemployed workers over the entire job search process.

- In 2005, the last reform package (Hartz IV) transformed the three-tier system of unemployment benefits, unemployment assistance, and subsistence benefits into a two-tier system of unemployment benefits and subsistence benefits.

- Concerning the benefit level, the reform involved abolishing unemployment assistance benefits (Arbeitslosenhilfe). The unemployment assistance depended on some previous work history and could be received for several years after unemployment insurance (UI) benefits expired. The net replacement rates were at $53 \%$ for a single person and could reach $57 \%$ for persons with dependent children. In addition, those who were not eligible for unemployment assistance were still eligible to receive a minimum subsistence benefit (Sozialhilfe) that included rent payments and was not dependent on previous wages. The reform of 2005 removed wage-dependent benefits for long-term unemployed, and merged unemployment assistance and subsistence benefits to create a new minimum benefit scheme (Arbeitslosengeld II) that is independent of previous wages and only intended to provide recipients with the minimum benefits necessary to survive. It is subject to a tight means testing procedure. In contrast, the unemployment insurance (UI) benefits (Arbeitslosengeld I) remained unchanged at a net replacement rate of $60 \%$ for single persons and $67 \%$ for those with dependent children. Note that we only focus on individuals who enter unemployment and receive UI benefits, thus, they were not affected by these benefit level changes targeted at those having exhausted UI benefits.

- Moreover, the fourth reform package involved changing the duration of unemployment benefits (see Table 7). These changes only came in effect for individuals claiming UI benefits after February 1, 2006 and brought significant cuts in UI benefit durations for individuals entering UI at an age above 45 . Via our identification strategy, we exploit this reform along with a later reform in 2008 that partially increased the UI benefit duration for some older age groups of benefit claimants again (Lichter, 2016). 
Over the course of the labor market reforms, the German government also introduced two new forms of government-funded/tax-subsidized private pension schemes. The so-called Riester Rente became effective on the 1st of January 2002 and is mainly attractive for wage workers and public servants with low to medium income. The so-called Rürup or Basis Rente became effective on the 1st of January 2005 is attractive mainly for wage workers with high income and self-employed individuals. Since we only analyse firm foundations from 2005 onwards, the availability of both schemes was similar for all founders in our sample. In addition, eligibility for both pension plans is independent of age and previous unemployment (duration) and hence should not interfere with our identification strategy (see Section 3).

\section{C.2 Startup Subsidies}

This section provides an overview of startup subsidies in Germany. Importantly, with respect to our identification strategy, all startup subsidies schemes were (and are) independent of the age of claimants and were not subject to changes at the same time when the reforms of potential unemployment insurance (UI) benefit duration (PBD) were introduced. Thus, the available startup subsidy schemes should not interfere with our identification strategy that exploits policy changes in PBD (as explained in Section 3). Moreover, we control for any funding provided by the German Federal Employment Agency (Bundesagentur für Arbeit) and/or the state-owned KfW bank (the development bank Kreditanstalt für Wiederaufbau, which was originally formed in 1948 to fund the reconstruction of Germany after World War II). By controlling for funding by the Federal Employment Agency, we effectively control for any startup subsidies targeted at founders starting a business out of unemployment. Funding via the $\mathrm{KfW}$ is the most important channel through which startups in Germany are subsidized in general (i.e. by subsidized credits that are administered and secured by KfW bank).

\section{Bridging Allowance (BA) - "Überbrückungsgeld” (1986-07/2006)}

- Eligibility: it covered individuals who were eligible for UI benefits, and presented an externally approved business plan (issued by the regional chamber of commerce). It was not possible to quit a job and directly apply for this bridging allowance.

- Amount: financial support was based on UI benefits plus social security contributions and it could be provided for up to six months.

- Until 2002, individuals had to stay unemployed for a minimum of one month to apply for BA. From 2002, one could apply for BA from the first unemployment day onward.

2. Existenzgründerzuschuss (Ich-AG) (startup subsidies (SUS)) (01/2003-06/2006)

- Eligibility: it covered individuals who were eligible for UI benefits, but also those with means-tested social assistance or limited labor market experience (hence it was open to more people than BA).

- Amount: it involved a monthly lump-sum payment for up to three years with 600 Euro per month in the first year, 360 Euro per month in the second year, 240 Euro per month in the third year. In contrast to BA, these startup subsidies were approved yearly if self-employment income did not exceed 25,000 Euro per year.

- There was no need of business plans for approval, but parallel receipts of BA and SUS were excluded. 
3. New SUS: new startup subsidy program (“Gründungszuschuss”) (08/2006-12/2011)

- Eligibility: it covered individuals that were unemployed for at least one day, eligible to receive UI (Arbeitslosengeld I) and that still had at least 90 days of potential UI benefit duration (PBD) left when making the transition from unemployment to self-employment. Thus, it was not possible to get this startup subsidy when an unemployed worker just exhausted her UI benefits.

- Amount: it involved UI benefits plus 300 Euro (for social security contributions) for nine months. It was possible to get an extension of six months by proving that the business is economically active. The amount of startup subsidies after the first nine months was reduced to just 300 Euro for the remaining six months. In total the startup subsidies could be taken for a maximum of 15 months.

- The first period of SUS could be legally claimed by all persons who fulfilled the legal eligibility requirements. The second period was entirely subject to an assessment.

- In case of returning from self-employment to unemployment, the PBD would be reduced by the number of months the person received SUS up to a minimum of zero PBD months.

4. New SUS adjusted: startup subsidy program (“Gründungszuschuss”) adjusted (01/2012-today)

- Eligibility: it covers individuals that are unemployed for at least one day, eligible to receive UI (Arbeitslosengeld I) and that still have at least 150 days (instead of previously 90 days) of potential UI benefit duration (PBD) left when making the transition from unemployment to self-employment. Thus, it is not possible to get this startup subsidy when an unemployed worker just exhausts her UI benefits.

- Amount: it involves unemployment insurance benefits plus 300 Euro (for social security contributions) for six (instead of previously nine) months. It is possible to get an extension of nine (instead of six) months by proving that the business is economically active. The amount of startup subsidies after the first nine months is reduced to just 300 Euro for the remaining six months. In total, the startup subsidies can be taken for a maximum of 15 months.

- The assessment for receiving startup subsidies has been extended to the first period. The previous legal right to claim this subsidy has been abolished by December 2011 and is now a subsidy that is available upon assessment of the caseworker at the federal employment agency.

- Background: as part of public spending cuts, the intention was to reduce money allocated for such active labor market policies. 


\section{Appendix: Model Extension}

\section{D.1 Model: Derivations and Details}

The Effect of Unemployment Duration on the Value of Searching for Employment Starting from the modeling framework as discussed in Section 5.1 with the value function of an unemployed individual searching for employment (Equation (8)), we have:

$$
\begin{aligned}
& V_{u, t}^{e}=b_{t}-\psi_{t}\left(s_{t}\right)+ \\
& \beta\left\{p_{t}\left[1-F\left(\phi_{t}\right)\right] \int_{\phi_{t}}^{\infty} V_{t+1}^{e}\left(w_{t+1}\right) d F\left(w_{t+1}\right)+\left[p_{t} F\left(\phi_{t}\right)+\left(1-p_{t}\right)\right] V_{t+1}^{u}\right\}
\end{aligned}
$$

This value function is increasing in the next period's wage $w_{t+1}$, such that the reservation wage plays an important role in the optimal search behavior. Every wage that is larger than the reservation wage, i.e. $w_{t+1} \geq \phi_{t}$, will be accepted. Therefore, we can write Equation (13) in terms of the following Bellman equation as:

$$
V_{u, t}^{e}=b_{t}-\psi_{t}\left(s_{t}\right)+\beta\left\{V_{t+1}^{u}+p_{t}\left[1-F\left(\phi_{t}\right)\right] \int_{\phi_{t}}^{\infty}\left[V_{t+1}^{e}\left(w_{t+1}\right)-V_{t+1}^{u}\right] d F\left(w_{t+1}\right)\right\}
$$

As mentioned in Section 5.1, $p_{t}=p\left(s_{t}, \theta\right)$. The case of leaving unemployment to employment is dependent on the search intensity and an unemployed individual's skill. Holding the level of ability $\theta$ fix, $p_{t}$ is directly dependent on the search intensity $s_{t}$, and can be substituted accordingly.

Further, defining the discount factor $\beta$ as $\frac{1}{1+\rho}$, with $\rho$ being the discount rate (see Schmieder and von Wachter, 2016), one can rewrite Equation (14) to:

$$
V_{u, t}^{e}=b_{t}-\psi_{t}\left(s_{t}\right)+\frac{1}{1+\rho}\left\{V_{t+1}^{u}+s_{t}\left[1-F\left(\phi_{t}\right)\right] \int_{\phi_{t}}^{\infty}\left[V_{t+1}^{e}\left(w_{t+1}\right)-V_{t+1}^{u}\right] d F\left(w_{t+1}\right)\right\}
$$

Assuming that the value of unemployment is in equilibrium equal to the discounted reservation wage, we define $V_{t+1}^{u}=\frac{1}{\rho} \phi_{t}$. Analogously, the value of leaving unemployment in the next period depends on the present value of the reservation wage $V_{u, t+1}^{e}=\frac{1}{\rho} \phi_{t}$, or in this case $V_{u, t}^{e}=\frac{1}{\rho} \phi_{t-1}$.

Note that the individual is indifferent between leaving unemployment or staying unemployed at the exact level of the reservation wage when $V_{u, t+1}^{e}=V_{t+1}^{u}$. Knowing the reservation wage $\phi_{t}$ and the optimal search intensity $s_{t}$ in period $t$ will enable us to detect the reservation wage in period $t-1$. Therefore, plugging in $V_{t+1}^{u}=\frac{1}{\rho} \phi_{t}, V_{t}^{u}=\frac{1}{\rho} \phi_{t-1}$ into Equation (15), we get:

$$
\frac{1}{\rho} \phi_{t-1}=b_{t-1}-\psi_{t}\left(s_{t}\right)+\frac{1}{1+\rho}\left\{\frac{1}{\rho} \phi_{t}+s_{t}\left[1-F\left(\phi_{t}\right)\right] \int_{\phi_{t}}^{\infty}\left[V_{t+1}^{e}\left(w_{t+1}\right)-\frac{1}{\rho} \phi_{t}\right] d F\left(w_{t+1}\right)\right\}
$$

Multiplying Equation (16) by $\rho(1+\rho)$, we get:

$$
(1+\rho) \phi_{t-1}=(1+\rho) \rho\left(b_{t-1}-\psi_{t}\left(s_{t}\right)\right)+\phi_{t}+s_{t}\left[1-F\left(\phi_{t}\right)\right] \int_{\phi_{t}}^{\infty}\left[\rho V_{t+1}^{e}\left(w_{t+1}\right)-\phi_{t}\right] d F\left(w_{t+1}\right)
$$


To find the optimal reservation wage, we need to derive the first-order conditions. With the optimal reservation wage implying indifference between the value functions for searching employment and for remaining unemployed (when $V_{u, t+1}^{e}=V_{t+1}^{u}$ ), we can further solve for the optimal search intensity (taking the derivative of Equation (17) for $s_{t}$ at the reservation wage $\phi_{t-1}$ ):

$$
(1+\rho) \rho \psi_{t}^{\prime}\left(s_{t-1}\right)-\left[1-F\left(\phi_{t-1}\right)\right] \int_{\phi_{t-1}}^{\infty}\left[\rho V_{t}^{e}\left(w_{t}\right)-\phi_{t-1}\right] d F\left(w_{t}\right)=0
$$

As mentioned in the main text, an unemployed individual receives a constant benefit $b_{t}$ for a duration $d$. When $t \geq d=P B D$, the benefit drops to a lower and constant level. This illustrates the importance of duration $d$. Since the reservation wage and the optimal search intensity are two choice variables that directly influence the value for employment, we are interested in their behavior over the unemployment duration spell $d$.

Exploiting the fact $V_{t+1}^{u}=\frac{1}{\rho} \phi_{t}$, the first order condition for the optimal reservation path is given by:

$$
\frac{\partial \phi_{t}}{\partial d}=\frac{\partial V_{t+1}^{u}}{\partial d} \rho
$$

Taking the total derivative of Equation (18) with respect to $d$, we get for the optimal search intensity path at period $t$ :

$$
\frac{\partial s_{t}}{\partial d}=-\frac{\partial \phi_{t}}{\partial d} \frac{\left[1-F\left(\phi_{t}\right)\right]^{2}+f\left(\phi_{t}\right) \int_{\phi_{t}}^{\infty}\left[\rho V_{t}^{e}\left(w_{t}\right)-\phi_{t}\right] d F\left(w_{t}\right)}{(1+\rho) \rho \psi_{t}^{\prime \prime}\left(s_{t}\right)}
$$

If there exists at least the slightest chance someone cannot find a job by the time unemployment benefits expire i.e. $t=d=P B D$, then a longer benefit duration in general increases the value for unemployment i.e. $\frac{\delta V_{t+1}^{u}}{\delta d}>0$. Equations (19) and (20) show that a longer $d$ will lead to a higher reservation wage $\phi_{t}$ and a lower search intensity $s_{t}$.

This means that given the hazard of leaving unemployment is given as $h_{t}=s_{t}\left(1-F\left(\phi_{t}\right)\right)$, an extension of $P B D$ would lower the probability of leaving unemployment in that period, thus increasing actual unemployment duration (compare also Schmieder and von Wachter, 2016). Moreover, this implies that the effect of unemployment duration on the value of searching for employment should be negative

$$
\frac{\partial V_{u t}^{e}}{\partial d} \mid \theta<0
$$

In other words, this model implies negative duration dependence which leads to the implications as described in the main text in Section 5. 
The Effect of Unemployment Duration on the Value of Searching for Self-Employment Starting from the modeling framework as discussed in Section 5.1 with the value function of an unemployed individual searching for employment (Equation (10)), we have:

$$
\begin{aligned}
& V_{u, t}^{s e}=b_{t}-\psi_{t}^{s e}\left(s_{t}, \theta\right)+ \\
& \beta\left\{p_{t}\left[1-F\left(\phi_{t}\right)\right] \int_{\phi_{t}}^{\infty} V_{t+1}^{s e}\left(\pi_{t+1}\right) d F\left(\pi_{t+1}\right)+\left[p_{t} F\left(\phi_{t}\right)+\left(1-p_{t}\right)\right] V_{t+1}^{u}\right\}
\end{aligned}
$$

Giving the same importance to the reservation wage and using the same definition for $\beta$ as in the case before, holding $\theta$ fixed we can rewrite the above equation in terms of the following Bellman equation as:

$$
V_{u, t}^{s e}=b_{t}-\psi_{t}^{s e}\left(s_{t}\right)+\beta\left\{V_{t+1}^{u}+p_{t}^{s e}\left[1-F\left(\phi_{t}\right)\right] \int_{\phi_{t}}^{\infty}\left[V_{t+1}^{s e}\left(\pi_{t+1}\right)-V_{t+1}^{u}\right] d F\left(\pi_{t+1}\right)\right\}
$$

This value function is again increasing in the next period's profits as income when being selfemployed $\pi_{t+1}$. Every potential profit as self-employed that is larger than the reservation wage, i.e. $\pi_{t+1} \geq \phi_{t}$, will be accepted. Note that the search costs have a different interpretation in this case. $\psi^{\text {se }}$ reflects costs related to developing a startup idea, doing the required research on it or finding capital. Furthermore, defining the discount factor $\beta$ as $\frac{1}{1+\rho}$, with $\rho$ being the discount rate, one can rewrite Equation (23) to:

$$
V_{u, t}^{s e}=b_{t}-\psi_{t}^{s e}\left(s_{t}\right)+\frac{1}{1+\rho}\left\{V_{t+1}^{u}+p_{t}^{s e}\left[1-F\left(\phi_{t}\right)\right] \int_{\phi_{t}}^{\infty}\left[V_{t+1}^{s e}\left(\pi_{t+1}\right)-V_{t+1}^{u}\right] d F\left(\pi_{t+1}\right)\right\}
$$

For the case of moving from unemployment to self-employment, we define $V_{u, t+1}^{s e}=\frac{1-\gamma(\bar{\theta})}{\rho} \phi_{t}$ : i.e. it depends also on the probability of startup success (survival), here for the average type at $\bar{\theta}$.

Note, that the individual is indifferent between leaving unemployment or staying unemployed at the exact level of the reservation wage when $V_{u, t+1}^{s e}=V_{t+1}^{u}$. Knowing the reservation wage $\phi_{t}$ and the optimal search intensity $s_{t}$ in period $t$ will enable us to detect the reservation wage in period $t-1$. Plugging in $V_{t+1}^{u}=\frac{1-\gamma(\bar{\theta})}{\rho} \phi_{t}, V_{t}^{u}=\frac{1-\gamma(\bar{\theta})}{\rho} \phi_{t-1}$ into Equation (24), we get:

$$
\begin{aligned}
\frac{1-\gamma(\bar{\theta})}{\rho} \phi_{t-1} & =b_{t-1}-\psi_{t}^{s e}\left(s_{t}\right) \\
+ & \frac{1}{1+\rho}\left\{\frac{1-\gamma(\bar{\theta})}{\rho} \phi_{t}+s_{t}^{s e}\left[1-F\left(\phi_{t}\right)\right] \int_{\phi_{t}}^{\infty}\left[V_{t+1}^{s e}\left(\pi_{t+1}\right)-\frac{1-\gamma(\bar{\theta})}{\rho} \phi_{t}\right] d F\left(\pi_{t+1}\right)\right\}
\end{aligned}
$$

After some rearranging we get:

$$
\begin{aligned}
& {[1-\gamma(\bar{\theta})](1+\rho) \phi_{t-1}=(1+\rho) \rho\left(b_{t-1}-\psi_{t}^{s e}\left(s_{t}\right)\right)} \\
& +(1-\gamma(\bar{\theta})) \phi_{t}+s_{t}^{s e}\left[1-F\left(\phi_{t}\right)\right] \int_{\phi_{t}}^{\infty}\left[\rho V_{t}^{s e}\left(\pi_{t+1}\right)-(1-\gamma(\bar{\theta})) \phi_{t}\right] d F\left(\pi_{t+1}\right)
\end{aligned}
$$


To find the optimal reservation wage, we again need to derive the first-order conditions. With the optimal reservation wage implying indifference between the value functions for becoming selfemployed and for remaining unemployed (when $V_{u, t+1}^{s e}=V_{t+1}^{u}$ ), we can further solve for the optimal search intensity (taking the derivative of Equation (26) for $s_{t}$ at the reservation wage $\phi_{t-1}$ ):

$$
(1+\rho) \rho \psi_{t-1}^{s e l}\left(s_{t-1}\right)-\left[1-F\left(\phi_{t-1}\right)\right] \int_{\phi_{t-1}}^{\infty}\left[\rho V_{t}^{s e}\left(\pi_{t}\right)-(1-\gamma(\bar{\theta})) \phi_{t-1}\right] d F\left(\pi_{t}\right)=0
$$

As mentioned in the main text, an unemployed individual receives a constant benefit $b_{t}$ for a duration $d$. When $t \geq d=P B D$, the benefit drops to a lower and constant level. This illustrates the importance of duration $d$. Since the reservation wage and the optimal search intensity are two choice variables that directly influence the value for employment, we are interested in their behavior over the unemployment duration spell $d$.

Exploiting the fact $V_{t+1}^{u}=\frac{(1-\gamma(\bar{\theta}))}{\rho} \phi_{t}$, the first order condition for the optimal reservation path is given by:

$$
\frac{\partial \phi_{t}}{\partial d}=\frac{\partial V_{t+1}^{u}}{\partial d} \frac{\rho}{(1-\gamma(\bar{\theta}))}
$$

Taking the total derivative of Equation (27) with respect to $d$, we get for the optimal search intensity path:

$$
\frac{\partial s_{t}}{\partial d}=-\frac{\partial \phi_{t}}{\partial d} \frac{\left[1-F\left(\phi_{t}\right)\right]^{2}+f\left(\phi_{t}\right) \int_{\phi_{t}}^{\infty}\left[\rho V_{t}^{s e}\left(\pi_{t}\right)-(1-\gamma(\bar{\theta})) \phi_{t}\right] d F\left(\pi_{t}\right)}{(1+\rho) \rho \psi_{t}^{\prime \prime}\left(s_{t}\right)}
$$

Again when unemployment benefit duration increases and there is chance of not finding a job when benefits expire, we expect that $\frac{\partial V_{t+1}^{u}}{\partial d}>0$. With $\rho$ being the discount rate taking values $<1$ and $[1-\gamma(\bar{\theta})]$ being the probability of startup success that is higher than $\rho$, the whole fraction is $\frac{\rho}{(1-\gamma(\bar{\theta}))}<$ 1. The denominator becomes larger, the higher an individual's ability $\theta$. Equations (28) and (29) show that searching market opportunities for self employment exhibits a smaller unemployment duration dependence of the reservation wage path $\left(\frac{\partial \phi_{t}}{\partial d}\right)$ and also a less negative duration dependence of the search intensity path $\left(\frac{\partial s_{t}}{\partial d}\right)$.

This implies that given Equation (22) the effect of unemployment duration on the value of searching for self-employment should be negative but less than in the case of searching for employment (compare Equation (21))

$$
\frac{\partial V_{u t}^{e}}{\partial d}\left|\theta<\frac{\partial V_{u t}^{s e}}{\partial d}\right| \theta<0
$$

In other words, this model implies negative duration dependence when searching for self-employment out of unemployment, however, it is less negative than the duration dependence when searching for employment. This leads to the implications as described in the main text in Section 5. Thus, $\frac{\partial V_{u t}^{s e}}{\partial d}$ is larger than in the case of searching for employment, i.e. there is a higher UI duration elasticity - which is in line with our empirical results in Section 4. 
Download ZEW Discussion Papers from our ftp server:

http://ftp.zew.de/pub/zew-docs/dp/

or see:

https://www.ssrn.com/link/ZEW-Ctr-Euro-Econ-Research.html

https://ideas.repec.org/s/zbw/zewdip.html

$$
\text { // }
$$

IMPRINT

ZEW - Leibniz-Zentrum für Europäische Wirtschaftsforschung GmbH Mannheim

ZEW - Leibniz Centre for European

Economic Research

L 7,1 68161 Mannheim · Germany

Phone +49621 1235-01

info@zew.de·zew.de

Discussion Papers are intended to make results of ZEW research promptly available to other economists in order to encourage discussion and suggestions for revisions. The authors are solely responsible for the contents which do not necessarily represent the opinion of the ZEW. 